\title{
Fatty acid modification and endothelial cell reactivity
}

Citation for published version (APA):

Vossen, R. C. R. M. (1993). Fatty acid modification and endothelial cell reactivity. [Doctoral Thesis, Maastricht University]. Datawyse / Universitaire Pers Maastricht. https://doi.org/10.26481/dis.19930506rv

Document status and date:

Published: 01/01/1993

DOI:

10.26481/dis.19930506rv

Document Version:

Publisher's PDF, also known as Version of record

\section{Please check the document version of this publication:}

- A submitted manuscript is the version of the article upon submission and before peer-review. There can be important differences between the submitted version and the official published version of record.

People interested in the research are advised to contact the author for the final version of the publication, or visit the DOI to the publisher's website.

- The final author version and the galley proof are versions of the publication after peer review.

- The final published version features the final layout of the paper including the volume, issue and page numbers.

Link to publication

\footnotetext{
General rights rights.

- You may freely distribute the URL identifying the publication in the public portal. please follow below link for the End User Agreement:

www.umlib.nl/taverne-license

Take down policy

If you believe that this document breaches copyright please contact us at:

repository@maastrichtuniversity.nl

providing details and we will investigate your claim.
}

Copyright and moral rights for the publications made accessible in the public portal are retained by the authors and/or other copyright owners and it is a condition of accessing publications that users recognise and abide by the legal requirements associated with these

- Users may download and print one copy of any publication from the public portal for the purpose of private study or research.

- You may not further distribute the material or use it for any profit-making activity or commercial gain

If the publication is distributed under the terms of Article $25 \mathrm{fa}$ of the Dutch Copyright Act, indicated by the "Taverne" license above, 


\section{Fatty Acid Modification and \\ Endothelial Cell Reactivity}

\section{PROEFSCHRIFT}

ter verkrijging van de graad van doctor aan de Rijksuniversiteit Limburg te Maastricht, op gezag van de Rector Magnificus, Prof. Mr. M.J. Cohen, volgens het besluit van het College van Dekanen, in het openbaar te verdedigen op donderdag, 6 mei 1993 om 16.00 uur

door

Renée Catherine Robert Marie Vossen

geboren te Maastricht op 24 december 1962

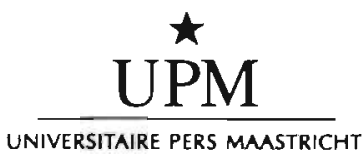




\section{Promotores:}

Prof. Dr. R.F.A. Zwaal

Prof. Dr. M.C.E. van Dam-Mieras, Open Universiteit

Co-promotor:

Dr. G. Hornstra

Beoordelingscommissie:

Prof. Dr. F. ten Hoor (voorzitter)

Prof. Dr. L.L.M. van Deenen, Rijksuniversiteit Utrecht

Prof. Dr. J. Jolles

Dr. P.J. Sims, Blood Research Institute, Milwaukee, USA

Prof. Dr. G.J. van der Vusse

Het verschijnen van dit proefschrift werd mede mogelijk gemaakt door financiële steun van:

- Nederlandse Hartstichting

- Dr. Ir. v.d. Laar Stichting 
Aan mijn ouders

Voor Michel 
Omslagontwerp: Puck Muller

Foto: Rein van Gool

Druk: Datawyse/Universitaire Pers Maastricht.

CIP-GEGEVENS KONINKLIJKE BIBLIOTHEEK, DEN HAAG

Vossen, Renée Catherine Robert Marie

Fatty acid modification and endothelial cell reactivity

Renée Catherine Robert Marie Vossen. Maastricht:

Universitaire Pers Maastricht.- Ill.

Proefschrift Maastricht. - Met lit. opg. - Met

samenvatting in het Nederlands.

ISBN 90-5278-070-6

NUGI 743

Trefw: Endotheelcellen/vetzuren/vaatziekten. 


\section{Contents}

List of Abbreviations $\quad 6$

$\begin{array}{lll}\text { Chapter } 1 \text { General Introduction } & 7\end{array}$

Chapter 2 Membrane Fatty Acid Composition and Endothelial Cell Functional Properties

Based on: Biochim. Biophys. Acta. 1991. 1083: 243-251

and: $\quad$ Advances in Prostaglandin, Thromboxane and Leukotriene Research. 1992. V21, Raven Press, New York: $237-240$

Chapter 3 Long-term Fatty Acid Modifications of Endothelial Cells: Implications for Arachidonic Acid Distribution in Phospholipid Classes

J. Lipid Res. 1993, in press

Chapter 4 Influence of Fatty Acid Modification on Complement Induced Prothrombinase Activity and PMA Induced von Willebrand Factor Release of Endothelial Cells

Chapter 5 Continuous Monitoring of Lipid Peroxidation by Measuring Conjugated Diene Formation in an Aqueous Liposome Suspension submitted for publication

Chapter 6 Differential Effects of Endothelial Cell Fatty Acid Modification on the Sensitivity of their Membrane Phospholipids to Peroxidation based on: Am. J. Clin. Nutr. 1993., in press

Chapter 7 Effects of Endothelial Cell Fatty Acid Composition on Hydrogen Peroxide Induced Cellular Injury

Chapter 8 General Discussion

Summary

Samenvatting

List of Publications

Curriculum Vitae

Nawoord 


\section{List of Abbreviations}

$\begin{array}{ll}\text { BHT } & \text { butylated hydroxytoluene } \\ \text { EDTA } & \text { Ethylenediaminetetracetic acid } \\ \text { HEPES } & \text { n-2-hydroxy-ethylpiperazine-n-2-ethanesulphonic acid } \\ \text { LDH } & \text { lactate dehydrogenase } \\ \text { MDA } & \text { malondialdehyde } \\ \text { PMA } & \text { phorbol myristate acetate } \\ \text { PMN } & \text { polymorphonuclear leukocyte } \\ \text { TBARS } & \text { thiobarbituric acid-reactive substances } \\ \text { TRIS } & \text { tetraethoxymethane } \\ \text { vWF } & \text { von Willebrand Factor } \\ \text { GLC } & \text { gas liquid chromatography } \\ \text { HPLC } & \text { high performance liquid chromatography } \\ \text { TLC } & \text { thin layer chromatography } \\ \text { SAFA } & \text { saturated fatty acid } \\ \text { MUFA } & \text { monounsaturated fatty acid } \\ \text { PUFA } & \text { polyunsaturated fatty acid } \\ \text { UI } & \text { unsaturation index } \\ \text { NL } & \text { neutral lipid } \\ \text { PL } & \text { phospholipid } \\ \text { SM } & \text { sphingomyelin } \\ \text { CP } & \text { choline phospholipid } \\ \text { PS } & \text { phosphatidylserine } \\ \text { PI } & \text { phosphatidylinositol } \\ \text { EP } & \text { ethanolamine phospholipid } \\ \text { 16:0 } & \text { palmitic acid } \\ 18: 0 & \text { stearic acid } \\ 18: 1(n-9) & \text { oleic acid } \\ \text { 18:2(n-6) } & \text { linoleic acid } \\ 18: 3(n-6) & \text { linolenic acid } \\ 20: 4(n-6) & \text { arachidonic acid } \\ 20: 5(n-3) & \text { eicosapentaenoic acid } \\ 22: 4(n-6) & \text { docosatetraenoic acid } \\ 22: 5(n-3) & \text { docosapentaenoic acid } \\ 22: 6(n-3) & \text { docosahexaenoic acid } \\ \text { C18:2 PC } & \text { phosphatidylcholine containing linoleic acid } \\ \text { C18:3 PC } & \text { phosphatidylcholine containing linolenic acid } \\ \text { C20:4 PC } & \text { phosphatidylcholine containing arachidonic acid } \\ & \\ & \end{array}$




\section{Chapter 1}

\section{General Introduction}

Both endothelial cells and dietary lipids are recognized to play a role in atherogenesis. A lot of research has been performed to study the influence of dietary lipids on several vascular parameters, such as blood pressure and blood flow, and on functional parameters of platelets, erythrocytes, monocytes and leukocytes [1-4]. However, the effects of dietary fatty acids on endothelial cell function have been studied to a lesser extent, probably because during culture of endothelial cells, necessary to obtain a pure population, their fatty acid composition no longer reflects that of the donor species. In this thesis we present our approach to this problem and study the effects of fatty acid modification on a variety of in vitro endothelial cell reactivities, that might be involved in atherogenesis.

\section{Atherosclerosis}

Atherosclerosis, forming one of the leading causes of death in industrialized countries, is a chronic process in the arterial wall. It is characterized by local thickening of the inner coat or intima, leading to irregular narrowing of the vascular lumen (stenosis) and consequently restriction of blood flow, and by a reduction in elasticity of the vessel wall (arteriosclerosis). One of the earliest recognizable thickenings is the 'fatty streak', formed by lipid accumulation. As atherosclerosis advances the 'fatty streak' develops into a 'fibrous plaque', a raised lesion covered by smooth muscle cells and connective tissue. Under the cell-rich lesion an area of necrotic debris, cholesterol crystals and calcification may develop (complicated plaque). The atherosclerotic lesions are characterized by the presence of deposits of lipid materials, remnants of thrombi, phagocytes and lymphocytes, smooth muscle cells and elements of connective tissue such as collagen, elastin, and glycosaminoglycans $[5,6]$. This indicates that local activation of the vascular wall by stimuli of an inflammatory and immunological nature most probably plays a role in atherogenesis, leading to secretion of growth factors and proliferation of smooth muscle cells. 
Atherogenesis is a multifactorial process in which dietary habits, lifestyle, environmental and genetic factors all play a role $[1,2]$. The question of how atherosclerosis is initiated is one of on-going research. For better understanding of this question, it will be crucial to know whether lipids play an initiating or a modulating role. The "response-toinjury hypothesis" postulated by Ross [5] proposes that the onset of atherosclerosis involves "injury" of the endothelial monolayer. During the development of atherosclerosis, various events are concurrently taking place which are essentially an attempt to repair the initial damage $[2,5,6]$. Monocytes adhere to the injured endothelium, migrate into the intima and transform into macrophages. These cells take up oxidized low density lipoprotein particles via their scavenger receptors to become lipid (cholesteryl esters) laden foam cells $[7,8]$. These low density lipoproteins may have been oxidatively modified by reactive oxygen metabolites produced by activated lymphocytes, monocytes and endothelial cells during inflammatory processes. Recently, Smith et al. [9] have shown that the contents of a human atherosclerotic lesion could stimulate lipid peroxidation and hydroxyl radical generation, indicating that peroxidative reactions play an important role in atherogenesis. Another relevant event, initiated by the release of various growth factors from the activated endothelial cells and macrophages, is the proliferation of smooth muscle cells. These proliferating cells secrete connective tissue proteins and glycosaminoglycans in the lesion $[5,10]$.

In summary, the development of atherosclerosis is considered to be a multifactorial process, among which a derailment of normal inflammatory and hemostatic processes occurring as a response to activation of the arterial wall. Endothelial cells, because of their characteristic localisation at the interface between circulatory system and tissues may play a crucial role in those processes. A broad range of stimuli may cause endothelial cell activation, which results in, among others, an increase in leukocyte adherence, transport of cells across the vascular wall, and all the processes referred to above. It will be evident that any modification that influences normal endothelial cell reactivity might contribute to these phenomena.

\section{Fatty acids}

From epidemiological studies (reviewed in $[1,2]$ ) evidence has been obtained that dietary lipids may influence the risk for coronary heart deseases. Many studies have been performed in experimental animals and man, investigating the influence of the amount and type of dietary lipid on plasma cholesterol levels (especially in low density lipoproteins), blood pressure, bleeding time, and on the functional activities of platelets, 
erythrocytes, monocytes, leukocytes, and vascular tissue [1-4]. In these studies changes in fatty acid composition were induced by dietary means, using crude lipid extracts and oils. A limitation of this is the presence of a variable fatty acid mixture in the oils used and of other compounds, such as antioxidants, that may interfere with the effects observed. Therefore, it would be interesting to perform these studies using triglycerides with a uniform fatty acid composition to induce modifications.

Dietary lipids are taken up and metabolized by the intestine and transported in plasma by the lipoproteins as esterified fatty acids and by albumin as free fatty acids. In the lipoprotein family, the chylomicrons and very low density lipoproteins predominantly carry triglycerides and the low or high density lipoproteins predominantly carry cholesteryl esters. Dietary fatty acids are delivered to the cells and tissues by interaction of the plasma lipoproteins and albumin with the cells via membrane receptors [11]. Consequently, dietary lipids will influence the fatty acid composition of plasma lipids, which together with cellular de novo synthesis will provide the fatty acids for cell membranes. Thus, dietary lipids will determine to a certain extent the fatty acid composition of cells in the blood and the vessel wall, and changes in membrane fatty acid composition might very well affect cell function [12-14]. Also, the membrane phospholipid composition and cholesterol content of cultured cells can be modified. Such an alteration may change membrane fluidity and affect a number of cellular functions, including carrier-mediated transport, properties of membrane-bound enzymes, receptor binding and function, exo- and endocytosis, immunologic cytotoxicity, eicosanoid production, and cell growth [13-15].

Lipids as determinants of membrane structure are potent and diverse modulators of cell functions. They influence membrane physico-chemical properties, facilitating membrane protein function (receptors, transport), and participate in cellular signal transduction, usually by cleavage of the lipid by various lipases to yield "second messengers" $[12,14]$. Upon cell stimulation, unsaturated fatty acids (especially arachidonic acid) are liberated from the membrane phospholipids, and converted via oxidative reactions to bioactive mediators (eicosanoids, hydroxy fatty acids) for regulation of intercellular communication and the inflammatory and hemostatic response (via vasodilation, vasoconstriction, platelet aggregation, leukocyte chemotaxis, etc.) [16]. In addition, the membrane phospholipid alkyl-phosphatidylcholine is converted to platelet activating factor, which may activate platelets, leukocytes, monocytes etc [12,17]. In response to various cell stimuli, phosphatidylinositol bisphosphate is hydrolyzed to yield diacylglycerols, which activate protein kinase $\mathrm{C}$, and inositol trisphosphate, which stimulates $\mathrm{Ca}^{2}+$ release from intracellular stores $[12,18]$. However, membrane fatty acids are not only a substrate for the formation of bioactive mediators, they also are an obvious target for an attack by reactive oxygen species, the formation of which usually 
accompanies cellular activation. This may lead to lipid peroxidation potentially harmful to the cell and its surroundings (see also "endothelial cell - reactivity").

In summary, fatty acids esterified to phospholipids, form an integral part of the biological membrane. The role fatty acids play in cellular functional activities can at least be considered two fold. On the one hand fatty acids, as part of phospholipids in biomembranes, contribute to creating a suitable microenvironment for membrane-associated processes. On the other hand fatty acids can actively participate in such processes by being used as a substrate for the formation of "communication molecules" or as target molecules for reactive oxygen intermediates formed during cell activation. Consequently, changes in membrane fatty acid composition may influence cellular reactivity, which can have implications for normal cell functioning and disease.

\section{Endothelial cell - culture}

The endothelial monolayer, forming the inner lining of all blood vessels, constitutes a dynamic barrier between the blood and the surrounding tissues. Endothelial cells are multifunctional and can influence circulating blood components as well as cells within the vessel wall. They play an important role in the regulation of vascular tone, vascular permeability, angiogenesis, hemostasis, inflammation and the immune response, by the expression and secretion of a variety of regulatory proteins and by modulating intercellular interactions [19-23]. For example, endothelial cells express angiotensin converting enzyme and produce endothelial derived relaxing factor (NO), endothelin and prostacyclin, they secrete growth factors, cytokines, von Willebrand factor, tissue plasminogen activator and its inhibitor, and they express tissue factor, thrombomodulin, adhesive receptors, platelet activating factor and major histocompatibility antigens. Thus, endothelial cells exert a crucial function at the interface between the circulatory system and tissues. They apparently can use a broad spectrum of strategies to regulate vascular adhesivity and permeability as circumstances may require.

For a long time, direct investigation of endothelial cell function was complicated by the lack of adequate methods that allowed the selective isolation of homogeneous populations of endothelial cells. The first attempts were made in 1922 by Lewis [24], who observed outgrowth of endothelial-like cells from various tissues, including blood vessels. Great improvement of yield and viability of human endothelial cells was achieved by Marayuma [25]. Since Jaffe et al. [26] modified this method to culture endothelial cells in vitro, it is widely used to study these cells under controlled conditions without interfering influences of other cell 
types present in arteries and veins (fibroblasts, smooth muscle cells). However, when culturing endothelial cells in the presence of serum, their fatty acid composition no longer reflects that of the donor species. Therefore, when studying the effects of membrane fatty acid composition on endothelial cell reactivity, it is necessary to develop a method to modify their fatty acid composition in vitro.

Cultured mammalian cells, in addition to de novo synthesis of lipids, can take up lipids from the culture medium for membrane synthesis. When the culture medium contains an adequate supply of lipids, as in the presence of serum, cellular de novo synthesis of fatty acids are suppressed $[14,27]$. This makes it possible to induce specific lipid modifications in cultured cells by controlling the type of lipids supplemented to the culture medium. Spector et al. $[13,28]$ first described modification of the fatty acid composition of endothelial cells in vitro by incubation with fatty acids supplemented to the serum in the culture medium. This procedure of incubating endothelial cells with supplemented fatty acids was reported to alter prostacyclin production [28-31], permeability properties of the endothelial monolayer [32], and sensitivity to oxidative injury [33,34]. It has also been reported that upon incubation of endothelial cells with oils emulsified in phosphatidylcholine resulted in alteration of the production of platelet derived growth factor [35].

A disadvantage of these studies is that the endothelial cells were only incubated with the supplemented fatty acids for a relatively short period ( 3 - 48 hours), but not really cultured for a longer period and therefore "equilibrium" was not reached. For example, elongation of supplemented fatty acids was reported to continue over 3 days [36]. We feel that longterm culture in fatty acid modified media is important to achieve remodelling of all phospholipid classes and thus to reaching a new steady state equilibrium, which may differently affect cell reactivity. Therefore, we developed a method of long-term fatty acid modification to study the influence on endothelial cell reactivity.

\section{Endothelial cell - reactivity}

"Injury" of endothelial cells may lead to aberrations in normal endothelial function, which is an important event in atherogenesis. Dietary lipids, which influence endothelial cell fatty acid composition, may induce changes in endothelial cell reactivity to hemostatic, inflammatory and oxidative processes.

Maintenance of vascular integrity is an important objective during response to injury. Complex mechanisms of coagulation, platelet function and fibrinolysis exist to minimize consequences of vascular injury and to 
accelerate vascular repair. Many of these hemostatic processes are regulated by endothelial cells $[16,23,37]$. Endothelial cells normally express anticoagulant properties to promote normal blood flow, including production of prostacyclin, tissue plasminogen activator, and the expression of thrombomodulin and protein S. Stimulated or perturbed endothelial cells can rapidly express procoagulant properties promoting local thrombin formation. Processes involved in this response are secretion of von Willebrand factor, and plasminogen activator inhibitor, and expression of platelet activation factor, tissue factor, factor $\mathrm{V}$ and binding sites for coagulation proteins.

Inflammatory reactions are another response to injury and many of these processes are regulated by endothelial cells $[16,22,38]$. An important step in inflammation is leukocyte adhesion to the endothelium, modulated by the expression of adhesive receptors, platelet activating factor, and eicosanoids. Complement C5b-9 activation of endothelial cells includes the induction of synthesis of eicosanoids, the secretion of high molecular weight multimers of von Willebrand factor, the translocation of P-selectin (a leukocyte adherence receptor) from the Weible-Pallade body to the cell surface, and the release of plasma membrane vesicles that display procoagulant activity. Each of these responses may potentiate inflammatory and hemostatic processes.

Endothelial cells are subject to oxidative stress during inflammatory reactions. For example, when activated polymorphonuclear leukocytes adhere to the endothelium, they release oxygen free radicals which may readily attack endothelial polyunsaturated fatty acids, membrane proteins and DNA resulting in membrane damage by lipid peroxidation and DNA damage, leading to oxidative cell injury [39-42]. During the respiratory burst of activated leukocytes, oxygen free radicals are generated, such as hydrogen peroxide $\left(\mathrm{H}_{2} \mathrm{O}_{2}\right)$, superoxide anion $\left(\mathrm{O}_{2}^{-}\right)$and hypochloric acid ( $\mathrm{HOCl}$ ) $\mathrm{H}_{2} \mathrm{O}_{2}$, the predominant reactive oxygen metabolite, can easily cross the endothelial membrane and may react with intra- and extracellular $\mathrm{Fe}^{2+}$ or $\mathrm{Cu}^{2}+$ to form the highly reactive and deleterious hydroxyl radical $(\mathrm{OH} \cdot)$ [43].

Oxidative reactions play an important role in normal cell function, such as normal respiration and eicosanoid production. These processes are carefully regulated and additional protected is provided by endogenous defense mechanisms against oxidative injury. This includes membraneassociated defenses, such as the free radical scavenger vitamin $E$, and cytoplasma associated defenses, such as vitamin $\mathrm{C}$, chelation of iron ions by ferritine and detoxification of reactive oxygen metabolites by superoxide dismutase (converting $\mathrm{O}_{2}^{-} \cdot$ to $\mathrm{H}_{2} \mathrm{O}_{2}$ ), catalase (converting $\mathrm{H}_{2} \mathrm{O}_{2}$ to $\mathrm{H}_{2} \mathrm{O}$ and $\mathrm{O}_{2}$ ) and the glutathione redox cycle $[41,43,44]$. However, when endogenous antioxidant systems are exhausted, oxygen free radicals can induce endothelial cell damage. Profound effects of $\mathrm{H}_{2} \mathrm{O}_{2}$ on endothelial cell function have been reported, such as altered prostacyclin 
release and signal transduction [45,46], elevated $\mathrm{Ca}^{2+}$ levels [46], ATP depletion [47], and DNA strand break formation [48]. Changes in membrane fatty acid composition might induce alterations in peroxidation capacity of membrane phospholipids, which might lead to different susceptibilities to oxidative injury of intact endothelial cells.

\section{Scope of the thesis}

The objective of this thesis was to study the influence of fatty acid composition on endothelial cell reactivity in vitro. This may contribute to understanding the association between the type of dietary lipid and atherosclerosis in vivo. Atherogenesis is considered to be a multifactorial process, among which a derailment of initially normal inflammatory and hemostatic processes accompanying vascular "injury", initiated and potentiated by a variety of factors. One of the contributing factors may be the type of dietary fatty acids, which influences the fatty acid composition of plasma and that of the endothelial cell membrane. This may affect endothelial cell reactivity and alter normal endothelial cell functioning, which might influence atherogenesis.

In order to study the effects of membrane fatty acid composition on endothelial cell reactivity, we first compared several methods to modify their fatty acid composition in vitro, using oleic acid as a model fatty acid. The results are described in chapter 2 . The most appropriate fatty acid modifying method, long-term culturing of endothelial cells in the presence of human serum supplemented with a fatty acid sodium salt, was used to modify the cells with a saturated, monounsaturated or polyunsaturated fatty acid. In chapter 3 we further investigated this fatty acid modification procedure at the level of the phospholipid classes. The influence of endothelial cell fatty acid modification on the incorporation, distribution and modification of arachidonic acid, a substrate for bioactive mediators, was studied in phospholipid classes using radiolabeled arachidonic acid.

This method of long-term fatty acid modification enabled us to study the effects of membrane fatty acid composition on several functional activities of endothelial cells. We measured the reactivity of endothelial cells in various general inflammatory and hemostatic processes as described in chapters 2 and 4 . In chapter 2 the effects of fatty acid modification on adherence of polymorphonuclear leukocytes and monocytes to the endothelial monolayer, and on the ability of an endothelial monolayer to facilitate the formation of a fibrin clot in human plasma (procoagulant activity) were studied. In these membraneassociated processes fatty acids are not active participants. Furthermore, the effect of fatty acid modification on eicosanoid production was studied. 
In this process certain fatty acids are active participants by being used as a substrate molecule. In chapter 4 the effects of fatty acid modification on cellular membrane related processes, such as the shedding of procoagulant microvesicles by complement-activated endothelial cells and the release of von Willebrand factor from their storage granules in the cells, were studied.

During inflammation endothelial cells are subject to oxidative stress, in which fatty acids, DNA and proteins are readily available target molecules. We developed a method for continuously monitoring the formation of conjugated dienes, early lipid peroxidation products from polyunsaturated fatty acids. This method is described in chapter 5. Using this method, we studied the effects of endothelial fatty acid modification on the sensitivity to peroxidation of their membrane phospholipids. The results of this study are presented in chapter 6 . In chapter 7 the influence of fatty acid modification on injury of intact endothelial cells (DNA damage and cell leakage) by short-term oxidative stress was investigated.

Chapter 8 summarizes the effects of fatty acid modification on endothelial cell reactivity.

\section{References}

1 Ulbricht, T.L.V.. and Southgate, D.A.T. 1991. Coronary heart disease: seven dietary factors. The Lancet. 338, 985-992

2 Gurr, M.I. 1992. Dietary lipids and coronary heart disease: old evidence, new perspective. Prog. Lipid Res. 31, 195-243

3 Herold, P.M., and Kinsella, J.E. 1986. Fish oil consumption and decreased risk of cardiovascular disease: a comparison of findings from animal and human feeding trials. Am. J. Clin. Nutr. 43, 566-598

4 G. Hornslra. 1989. The significance of fish and fish-oil enriched food for prevention and therapy of ischaemic cardiovascular disease. in: The role of fats in human nutrition. (Vergoesen, A.J., and Crawtord, M., eds.) 2nd ed., Academic Press, London, Pp 151-235

5 Ross, R. 1986. The pathogenesis of atherosclerosis - and update. N. Engl. J. med. 314, 488-500

6 Bruggeman, D.A., and van Dam-Mieras, M.C.E. 1991. The possible role of cytomegabvins in atherogenesis.in: Prog. Med. Virol. (Melnick, J.L., ed) V38, Karger, Basel, pp. 1-26

7 Rosenfeld, M.E., Palinsky, W., Ylä-Herttuala, S., and Carew, T.E. 1990. Macrophages, endothelial cells and lipoprotein oxidation in the pathogenesis of atherosclerosis. Toxicol. Pathol. 18, 560-571

8 Parthasarathy, S., Steinberg, S., and Witztum, J.L. 1992. The role ol oxidized low-density lipoprotein in the pathogenesis of atherosclerosis. Annu. Rev. Med. 43, 219-225

9 Smith, C., Mitchinson., M.J., Aruoma, O.I., and Halliwell, B. 1992. Stimulation of lipid peroxidation and hydroxyl-radical generation by the contents of human atherosclerotic lesions. Biochem. J. 286, 901-905

10 DiCorleto. P.E., and Chisolm, G.M. 1986. Participation of the endothelium in the development of the atherosclerotic plaque. Prog. Lipid Res. 25, 365-374

11 Gotto, A.M., Pownall, H.J., and Havel, R.J. 1986. Introduction to the plasma lipoproteins. Methods Enzymol. 128, 3-41

12 Merrill, A.H. 1989. Lipid modulators of cell function. Nutr. Rev. 47, 161-169

13 Spector, A.A., and Yorek, M.A. 1985. Membrane lipid composition and cellular function. J. Lipid Res. 26, 1015-1035 
14 Stubbs, C.D., and Smith, A.D. 1984. The modification of mammalian membrane polyunsaturated fatty acid composition in relation to membrane fluidity and function. Biochim. Biophys. Acta 779, 89-137

15 Hoffmann, P., and Mest, H.J. 1987. What about the effects of dietary lipids on endogeneous prostanoid synthesis. A state-of-the-ant review. Biomed. Biochim. Acta 46, 639-650

16 Smith, W.L. 1989. The eicosanoids and their biochemical mechanisms of action. Biochem. J. $259,315-324$

17 Whatley, R.E., Zimmerman, G.A., Mcintyre, T.M., and Prescoth, S.M. 1990. Lipid metabolism and signal transduction in endothelial cells. Prog. Lipid Res. 29, 45-63

18 Shinomura, T., Asaoka, Y., Oka, M. Yoshida, K., and Nishizuka, Y. 1991. Synergistic action of diacylglycerol and unsaturated fatty acid for protein kinase $C$ activation: its possible implications. Proc. Natl. Acad. Sci. USA. 88, 5149-5153

19 Jaffe, E.A. 1985 Physiologic functions of normal endothelial cells. Ann. N.Y. Acad. Sci. 454, 279-291

20 Gimbrone, M.A. 1986. Vascular endothelium: nature's blood container. in: Vascular endothelium in hemostasis and thrombosis (Gimbrone, M.A., ed.) pp 1-13, Churchill Livingstone inc., New York

21 Fajardo, L.F. 1989. The complexity of endothelial cells. Am. J. Clin. Pathol. 92, 241-250

22 Pober, J.S., and Cotran, R.S. 1990. The role of endothelial cells in inflammation. Transplantation $50,537-544$

23 Rodgers, G.M. 1988. Hemostatic properties of normal and perturbed vascular cells. FASEB J. $2,116-123$

24 Lewis, W.H. 1922. Endothelium in tissue culture. Am. J. Anat. 30, 39-59

25 Marayuma, $Y$. 1963. The human endothelial cell in tissue culture. Z. Zellforsch. 60, 69-79

26 Jaffe, E.A., Nachman, R.L., Becker, C.G., and Minick, C.R. 1973. Culture of human endothelial cells derived from umbilical veins: indentification by morphologic and immunologic criteria. J. Clin. Invest. 52, 2745-2756

27 Spector, A.A., Mathur, S.N., Kaduce, T.L., and Hyman, B.T. 1981. Lipid nutritution and metabolism of cultured mammalian cells. Prog. Lipid Res. 19, 155-186

28 Spector, A.A., Hoak, J.C., Fry, G.L., Denning, G.M., Stoll, L.L., and Smith J.B. 1980. Effect of fatty acid modification on prostacyclin production by cultured human endothelial cells. J. Clin. Invest. 65, 1003-1012

29 Lagarde, M., Croset, M. Sicard, B., and Dechavanne, M. 1986. Biological activities and metabolism of eicosenoic acids in relation to platelet and endothelial function. Prog. Lipid Res. 25, 269-271

30 Brox, J.H., and Nordøy, A. 1983. The effect of polyunsalurated fatty acids on endothelial cells and their production of prostacyclin, inromboxane and platelel inhibilory activity. Thromb. Haemostasis 50, 762-767

31 Chun-Lan, Z., Lyngmo, V., and Norday, A. 1992. The effects of saturated fatty acids on endothelial cells. Thromb. Res. 65, 65-75

32 Henning, B., and Watkins, B.A. 1988. Linoleic acid and linolenic acid: effect on permeability properties of cultured endothelial cell monolayers. Am. J. Clin. Nutr. 49, 301-305

33 Hart, C.M., Tolson, J.K., and Block, E. 1991. Supplemental fatty acids alter lipid peroxidation and oxidant injury in endothelial cells. Am. J. Physiol. 260, L481-L488

34 Hart, C.M., Tolson, J.K., and Block, E. 1990. Falty acid supplementation prolecls pulmonary artery endothelial cells from oxidant injury. Am. J. Resp. Cell Mol. Biol. 3, 479489

35 Fox, P.L., and DiCorleto, P.E. 1988. Fish oils inhibit endothelial cell production of plateletderived growth factor-like protein. Science 241, 453-456

36 MacDonald, J.I.S., and Sprecher, H. 1991. Phospholipid fatty acid remodeling in mammalian cells. Biochim. Biophys. Acta 1084, 105-121

37 Nawroth, P.P. Handley D., Slern, D.M. 1986. The multiple levels of endothelial cellcoagulation factor interactions. Clin. Haematol. 15, 293-321

38 Morgan, B.P. 1989. complement membrane attack on nucleated cells: resistance, recovery and non-lethal eflects. Biochem. J. 264, 1-14

39 Ward, P.A. 1991. Mechanisms of endothelial cell killing by $\mathrm{H}_{2} \mathrm{O}_{2}$ or products of activated neutrophils. Am. J. Med. 91, 89S-93S

40 Nathan, C.F. 1987. Neutrophil activation on biological surfaces. J. Clin. Invest. 80, 15501560

41 Halliwell, B., and Gutteridge, J.M.C. 1989. Free radicals, ageing and disease in: Free Radicals in Biology and Medicine. (Hallwell, B., and Gulteridge, J.M.C., eds.), 2nd ed., Oxford University Press, Oxford, pp. 416-508 
42 Halliwell, B., Gutteridge, J.M., and Cross, C.E. 1992. Free radicals, antioxidants, and human disease: where are we now? J. Lab. Clin. Med. 119, 598-620

43 Hiraishi, H., Terano, A., Razandi, M. Sugimolo, T., Harada, T., and Ivey, K.J. 1992. Role of cellular superoxide dismutase against reactive oxygen metabolite injury in cultured bovine aortic endothelial cells. J. Biol. Chem. 267,14812-14817

44 Harian, J.M., Levine, J.D., Callahan, K.S., and Schwartz, B.R. 1984. Glutathione redox cycle protects cultured endothelial cells against lysis by extracellularty generated hydrogen peroxide. J. Clin. Invest. 73, 706-713

45 Vercellotti, G.M., Severson, S.P., Duane, P., and Moldow, C.F. 1991. Hydrogen peroxide alters signal transduction in human endothelial cells. J. Lab. Clin. Med. 117, 15-24

46 Shasby, D.M., Yorek, M., and Shasby, S.S. 1988. Exogenous oxidants initiate hydrolysis of endothelial cell inositol phospholipids. Blood 72, 491-499

47 Thies, R.L., and Autor, A.P. 1991. Reactive oxygen injury to cultured pulmonary artery endothelial cells: mediation by Poly(ADP-ribose)polymerase activation causing NAD+ depletion and altered energy balance. Arch. Biochem. Biophys. 286, 353-363

48 Spragg, R.G. 1991. DNA strand break formation following exposure of bovine puimonary artery and aortic endothelial cells to reactive oxygen products. Am. J. Respir. Cell Mol. Biol. 4, 4-10 


\section{Chapter 2}

\section{Membrane Fatty Acid Composition and Endothelial Cell Functional Properties}

Renée C.R.M. Vossen, Maria C.E. van Dam-Mieras,

Paul J.M.R. Lemmens, Gerard Hornstra, Robert F.A. Zwaal.

based on: Biochim. Biophys. Acta. 1991. 1083: 243-251

and: $\quad$ Advances in Prostaglandin, Thromboxane and Leukotriene Research. 1991. V21, Raven Press, New York: 237-240 


\begin{abstract}
In order to study the influence of endothelial cell fatty acid composition on various membrane related parameters, several in vitro methods were developed for manipulating the fatty acid content of human endothelial cell membranes. Changes in membrane fatty acid profile were induced by using fatty acid modified lipoproteins or free fatty acids. The largest changes in endothelial fatty acid composition were obtained by culturing the cells in media supplemented with a specific free fatty acid. An increase in arachidonic acid content of endothelial phospholipids was induced by supplementation with saturated fatty acids or with arachidonic acid itself. A decrease in arachidonic acid content was obtained by supplementation with other unsaturated fatty acids. Under the experimental conditions used endothelial cells showed a low desaturase activity and a high elongase activity.
\end{abstract}

Considerable alterations in membrane fatty acid composition did not greatly influence certain membrane related parameters such as endothelial cell procoagulant activity and adherence of polymorphonuclear leukocytes and monocytes. In general, for fatty acid modified endothelial cells an association between a lowering in arachidonic acid content of endothelial cell membranes and a decrease in eicosanoid production was found.

This study demonstrates that considerable changes in membrane fatty acid profile affect endothelial cell arachidonic acid metabolism, but it also illustrates 'homeostasis' at the level of endothelial cell functional activity. 


\section{Introduction}

Endothelial cells lining the inner surface of the circulatory system, constitute a dynamic barrier between blood and the surrounding tissues. Endothelial cells are multifunctional and can influence circulating blood cells as well as other cells within the vessel wall [1]. They are metabolically active, physiologically responsive, susceptible to injury and play a role in the pathogenesis of atherosclerosis $[1,2]$.

Epidemiological studies have shown that the type of dietary lipid is a risk factor for the development of cardiovascular disease $[3,4,5]$. As the fatty acid composition of cellular membranes and plasma lipids reflects that of dietary lipids [6], dietary induced changes in fatty acid composition of endothelial cell membranes may influence cellular eicosanoid metabolism and other membrane related cellular parameters relevant to atherogenesis $[8,9]$. However, the direct effect of dietary fatty acids on endothelial cell function is poorly understood. Insight into the relationship between the fatty acid composition of endothelial cell membranes and cellular reactivity may contribute to understanding the correlation between dietary lipids and cardiovascular disease.

Many studies have shown that the fatty acid composition of cellular membranes can be modified. Most modifications in membrane lipid are produced in vivo by diets $[3,5,7]$. Other studies induce fatty acid changes in vitro $[9,10]$. Cultured mammalian cells can take up lipids from the culture medium for membrane synthesis. When the culture medium contains an adequate supply of lipids, the endogenous syntheses of fatty acids and cholesterol are suppressed [8]. Thus, specific lipid modifications in cultured cells can be produced by controlling the type of lipids supplemented to the culture medium. Another advantage of working in an in vitro system is that endothelial cells can be studied under standardized conditions without influences of other vessel wall components.

In this study the influence of membrane fatty acid composition on endothelial cell functional properties relevant to haemostatic and inflammatory processes was investigated. Several in vitro methods for manipulating the fatty acid composition of normally growing endothelial cells were developed. The most efficient method appeared to be supplementation of specific free fatty acids to the culture medium of endothelial cells. This method enabled us to study the influence of a specific fatty acid modification on endothelial membrane related functional properties, such as polymorphonuclear leukocyte adherence, endothelial cell procoagulant activity and eicosanoid synthesis. 


\section{Materials and Methods}

Culture media M199 and RPMI1640 (with L-glutamine and $20 \mathrm{mM}$ HEPES) were obtained from Flow lab. $60 \mathrm{~cm}^{2}$ tissue culture dishes were from Falcon (F3003), 96 well strips from Nunc Inc. and Thermanox cover slips (round, 15 $\mathrm{mm}$ ) were from Lux Inc. Ethylenediaminetetracetic acid (EDTA), n-2-hydroxyethylpiperazine-n-2-ethanesulphonic acid (HEPES) and L-glutamin were obtained from Serva. 2.5\% (w/v) trypsin solution was from Flow lab. Human fibronectin was a kind gift from Dr. J. van Mourik (CLB, Amsterdam). Rabbitanti-human von Willebrand factor immunoglobulin was obtained from Central Laboratory for Blood Transfusion (Amsterdam), swine-anti-rabbit immunoglobulin was from Dakopatts, 1,1'-dioctadecyl-1,3,3,3',3-tetramethylindocarbocyanine perchlorate acetylated low density lipoprotein was from Biomedical Technologies Inc. Thrombin was obtained from Hoffmann-la Roche Diagnostica. Free fatty acids and their sodium salts were obtained from Sigma.

Several buffers were used; phosphate buffered saline: $0.137 \mathrm{M} \mathrm{NaCl}, 2.6 \mathrm{mM}$ $\mathrm{KCl}, 8.1 \mathrm{mM} \mathrm{Na} 2 \mathrm{HPO}_{4}, 1.15 \mathrm{mM} \mathrm{KH} \mathrm{PO}_{4}$ (pH 7.4). Hank's buffer: $0.137 \mathrm{M}$ $\mathrm{NaCl}, 6.8 \mathrm{mM} \mathrm{KCl}, 1.3 \mathrm{mM} \mathrm{CaCl} 2.2 \mathrm{H}_{2} \mathrm{O}, 0.8 \mathrm{mM} \mathrm{MgSO} 4.7 \mathrm{H}_{2} \mathrm{O}, 0.45 \mathrm{mM}$ $\mathrm{Na}_{2} \mathrm{HPO}_{4} .2 \mathrm{H}_{2} \mathrm{O}, 0.45 \mathrm{mM} \mathrm{KH} 2 \mathrm{PO}_{4}, 10 \mathrm{mM}$ HEPES (pH 7.2). Michaelis buffer: $0.15 \mathrm{M} \mathrm{NaCl}, 0.15 \mathrm{M} \mathrm{Na}$-veronal, $0.109 \mathrm{M} \mathrm{Na}$-citrate $\mathrm{pH}$ 7.35. Trypsin solution: $0.125 \%(\mathrm{w} / \mathrm{v})$ trypsin (Flow) in phosphate buffered saline containing EDTA $(0.33 \mathrm{mM})$. The culture medium consisted of M199/RPMI1640 (1:1, v/v) supplemented with L-glutamine $(2 \mathrm{mM})$, gentamicin $(50 \mathrm{mg} / \mathrm{ml}), \mathrm{NaHCO}_{3}(11.9$ $\mathrm{mM})$ and endothelial cell growth supplement (100 $\mu \mathrm{g}$ protein/ml). Endothelial cell growth supplement was prepared from bovine brain as described by Maciag et al. [11].

All chemicals used were of the highest grade of purity available.

\section{Preparation of lipid-modified media}

High density lipoprotein and lipoprotein depleted serum were prepared by ultracentrifugation using a modification of the method described by Terpstra et al. [12]. Briefly, $1150 \mathrm{mg} \mathrm{KBr}$ was added to $3 \mathrm{ml}$ human serum to adjust the density to $\mathrm{d}=1.25 \mathrm{~g} / \mathrm{ml}$. The serum was placed in a centrifugation tube and overlayed sequentially with $1.6 \mathrm{ml} \mathrm{KBr}(2.58 \mathrm{M}, \mathrm{d}=1.21 \mathrm{~g} / \mathrm{ml}), 3 \mathrm{ml} \mathrm{KBr}(1.12$ $\mathrm{M}) / \mathrm{NaCl}(0.20 \mathrm{M})(\mathrm{d}=1.10 \mathrm{~g} / \mathrm{ml}), 2 \mathrm{ml} \mathrm{NaCl}(0.53 \mathrm{M}, \mathrm{d}=1.019 \mathrm{~g} / \mathrm{ml})$ and $1.5 \mathrm{ml}$ distilled water. The tubes were centrifuged for 18 hours at $20^{\circ} \mathrm{C}$ in an ultracentrifuge (Beckman) with a swing-out rotor (SW40) at $28,400 \times \mathrm{g}$. The high density lipoprotein fraction $(1.08 \mathrm{~g} / \mathrm{ml}<\mathrm{d}<1.21 \mathrm{~g} / \mathrm{ml})$ and the bottom fraction of lipoprotein depleted serum $(\mathrm{d}>1.21 \mathrm{~g} / \mathrm{ml})$ were collected and dialyzed extensively against three changes of saline $(0.15 \mathrm{M} \mathrm{NaCl})$ and a final change of M199/RPMI $1640(1: 1, \mathrm{v} / \mathrm{v})$. The high density lipoprotein and lipoprotein depleted serum fractions were mixed and sterilized by filtration $(0.22 \mu \mathrm{m})$.

Dioleoylphosphatidylcholine vesicles were prepared by dissolving dioleoyl phosphatidyl choline in ethanol, followed by evaporation of the ethanol, sonication in sterile phosphate-buffered saline, and filtration $(0.22 \mu \mathrm{m})$. Several lipid-modified media were prepared. Medium 1, the standard culture medium, which consisted of culture medium/human serum $(80: 20, v / v)$ without any supplement, served as control medium. Medium 2 consisted of culture medium/human serum $(80 / 20, v / v)$, supplemented with $200 \mu \mathrm{M}$ dioleoylphosphatidylcholine vesicles. Medium 3 consisted of culture medium/ lipo- 
protein depleted serum with high density lipoprotein $(80: 20, v / v)$, supplemented with $200 \mu \mathrm{M}$ dioleoylphosphatidylcholine vesicles. In the preparation of media 2 and 3 the vesicles were mixed with warm human serum $\left(37^{\circ} \mathrm{C}\right)$ or with a warm solution of lipoprotein depleted serum and high density lipoprotein $\left(37^{\circ} \mathrm{C}\right)$, prior to addition of culture medium. Medium 4 consisted of culture medium/human serum $(80: 20, \mathrm{v} / \mathrm{v})$, supplemented with $200 \mu \mathrm{M}$ oleate; Sodium oleate was added dropwise to warm human serum $\left(37^{\circ} \mathrm{C}\right)$ prior to addition of culture medium. Sodium salts of other fatty acids were added by the same procedure (palmitate and stearate solutions contained some $\mathrm{N}$-acety- $\beta$-D-glucopyranoside $(0.2 \mathrm{nM})$ ).

\section{Endothelial cell culture}

Endothelial cells were obtained from human umbilical cord veins by trypsin digestion according to Astaldi et al. [13]. The cells were seeded into fibronectin coated $\left(200 \mu \mathrm{g} / \mathrm{ml}\right.$ fibronectin incubated $30 \mathrm{~min}$ at $\left.37^{\circ} \mathrm{C}\right)$ tissue culture dishes $\left(60 \mathrm{~cm}^{2}\right.$, Falcon) and continued at $37^{\circ} \mathrm{C}$ in an atmosphere of $5 \% \mathrm{CO}_{2}$ in standard medium consisting of culture medium /human serum $(80: 20, \mathrm{v} / \mathrm{v})$. At confluency, the cultures were trypsinized and subcultured into 3 new fibronectin coated tissue culture dishes (passage 1). At $90 \%$ confluency, cells were trypsinized, cooled slowly to $-70^{\circ} \mathrm{C}$ in culture medium/human serum/ dimethylsulphoxide (50:40:10,v/v/v) and kept in liquid nitrogen, or used directly for fatty acid modification. The cells were identified as endothelial cells by morphology, by immunofluorescent staining for human von Willebrand factor [13] and by the uptake of 1,1'-dioctadecyl-1,3,3,3',3-tetramethyl-indocarbocyanine perchlorate acetylated low density lipoprotein.

\section{Fatty acid modification of endothelial cells}

Endothelial cells were taken out of the liquid nitrogen and resuspended into standard culture medium. They were seeded into fibronectin coated tissue culture dishes and continued at $37^{\circ} \mathrm{C}$ in an atmosphere of $5 \% \mathrm{CO}_{2}$ (passage 2). At confluency, the cells were trypsinized and subcultured into 3 new culture dishes (passage 3). From passage 3 to 5 (about 7 or 8 days) endothelial cells were cultured in the lipid-modified media. If endothelial cells were not frozen but used directly, they were cultured from passage 2 to 4 in fatty acid modified media. The number of population doublings was similar for all modified cells.

\section{Lipid analysis.}

Endothelial cell monolayers were washed twice with phosphate buffered saline containing $0.33 \mathrm{mM}$ EDTA (buffer A). The cells were trypsinized and washed twice with buffer $A$ at $4^{\circ} \mathrm{C}$, counted in a coulter counter and frozen in buffer $\mathrm{A}$ at $-70^{\circ} \mathrm{C}$.

For fatty acid analysis the cells were thawed rapidly and the lipids were extracted according to Bligh and Dyer [14]. Aliquots were taken to quantify phosphorus content according to Böttcher et al. [15] and cholesterol content using reagents provided by a kit (free cholesterol: enzymatic colorimetric test kit, Boehringer). Phospholipids were separated from neutral lipids by thin layer chromatography and subsequently fatty acids of the phospholipid fraction were analysed by gas liquid chromatography according to Rand et al. [5]. 


\section{Cell proliferation assay}

Proliferation of endothelial cells was measured by bromodeoxyuridine incorporation as described by Lichtenbeld et al. [32]. Briefly, endothelial cells were cultured in fatty acid modified media in 6-well culture dishes. At confluency (passage 4), the cells were washed and incubated with culture medium supplemented with bromodeoxyuridine $(10 \mu \mathrm{M}$ final concentration) for $30 \mathrm{~min}$. The cells were trypsinized, cytospin preparations were prepared and stained with anti-bromodeoxyuridine and hematoxilin as described [32]. In each cytospin the percentage of bromodeoxyuridine-positive cells was scored. The Mann-Whitney test was used for statistical analysis.

\section{Polymorphonuclear leukocyte and monocyte adhesion assay.}

Human polymorphonuclear leukocytes and monocytes were isolated from citrated human blood and adherence to endothelial cells was measured according to Span et al. [16]. Endothelial cells (passage 4 or 5) were cultured on fibronectin-coated thermanox cover slips (Lux) in the fatty acid modified media. At confluency, the endothelial monolayer was washed and incubated for $20 \mathrm{~min}$ with Hank's buffer or with thrombin (1 U/ml in Hank's buffer). Then, the monolayer was washed twice with Hank's buffer and incubated with the polymorphonuclear leukocyte suspension $(4.105$ polymorphonuclear leukocytes/cover slip) or monocytes for $15 \mathrm{~min}$ at $37^{\circ} \mathrm{C}$. Next, the cover slips were washed to remove nonadherend cells, and after staining with May GrünwaldGiemsa endothelial cells and adhering polymorphonuclear leukocytes or monocytes were counted as described by Span et al. [16]. The Mann-Whitney test was used for statistical analysis.

\section{Endothelial cell procoagulant activity assay.}

Procoagulant activity exposed on the intact endothelial cell surface was measured using an adaptation of the method previously described by Muller et al. [17]. Briefly, endothelial cells (passage 4 or 5) were cultured in the fatty acid modified media in 96 well strips (Nunc) precoated with fibronectin $(1 \mathrm{mg} / \mathrm{ml}$ ). At confluency, the cells were washed and incubated with Hank's buffer or with thrombin $\left(1 \mathrm{U} / \mathrm{ml}\right.$ in Hank's buffer) for $20 \mathrm{~min}$ at $37^{\circ} \mathrm{C}$. Then the endothelial monolayer was washed twice with Hank's buffer and incubated with 180 $\mu \mathrm{l} /$ well pooled normal human plasma/Michaelisbuffer $\mathrm{pH} 7.4(1: 1, \mathrm{v} / \mathrm{v})$ at $37^{\circ} \mathrm{C}$. After $15 \mathrm{~min} 90 \mu \mathrm{l} /$ well $\mathrm{CaCl}_{2}(0.033 \mathrm{M})$ was added and the clotting time was measured.

\section{Eicosanoid analysis.}

Endothelial cell monolayers (passage 4 or 5) were washed twice and incubated for $15 \mathrm{~min}$. at $37^{\circ} \mathrm{C}$ with Hank's buffer (blank) or with thrombin (1 $\mathrm{U} / \mathrm{ml}$ in Hank's buffer). The supernatants were collected for eicosanoid analysis and kept at $-20^{\circ} \mathrm{C}$ until analyzed. Eicosanoids were analyzed by high performance liquid chromatography as described by Engels et al. [18]. 


\section{Results}

Comparison of various methods for endothelial cell membrane modification

In preliminary experiments endothelial cells were cultured in serum free culture medium supplemented with low density lipoprotein. Under these experimental conditions the oleic acid content of endothelial cell membranes increased from $16.8 \%$ to $27.8 \%$ when dioleoylphosphatidylcholine vesicles were added to this culture medium. However, cell growth was reduced and endothelial cells showed a spindle-shaped appearance. Moreover, serum was still required for a short period after seeding to allow attachment and spreading of the cells after trypsinization. Therefore, serum was used in the culture media of further experiments, which resulted in normal cell growth and a cobblestoned morphologic appearance at confluency.

Various lipid-modified media were tested for their capacity to modify the oleic acid content of endothelial cells, while supporting normal cell growth. Endothelial cells were cultured in standard culture medium till passage 3. Subsequently, the cells were cultured in various lipid-modified media from passage 3 to 5 as indicated (table 1). The results for modification of the oleic acid content by various culture methods are shown in table 1 .

Table 1. Modification of the oleic acid content of endothelial cell phospholipids by various culture methods

\begin{tabular}{lc}
\hline culture medium supplement & $\begin{array}{c}\text { oleic acid content } \\
\text { in total phosphol }\end{array}$ \\
\hline medium 1) Human serum & $18.2(0.3)$ \\
medium 2) Human serum + DOPC & $20.8(0.3)$ \\
medium 3) LPDS + HDL + DOPC & $30.9(0.5)$ \\
medium 4) Human serum + oleate & $38.8(0.9)$
\end{tabular}

Cells were cultured from passage 3 to 5 in various lipid-modified culture media consisting of standard culture medium with various supplements as indicated. Then, the cells were trypsinised, phospholipids were extracted and fatty acid compositions were determined as described in Materials and Methods. Data are mean values (SD) from 2-3 separate cultures. Abbreviations: LPDS, lipoprotein depleted serum; DOPC, dioleoylphosphatidylcholine vesicles; HDL, high density lipoprotein

Endothelial cells grown in standard culture medium (method 1) without lipid supplementation served as control cells, containing $18.2 \%$ oleic acid in total phospholipids (table 1). When endothelial cells were grown in standard culture medium supplemented with $200 \mu \mathrm{M}$ dioleoylphosphatidylcholine vesicles (method 2), the oleic acid content of total phospholipids was only slightly changed. When the concentration of 
dioleoylphosphatidylcholine vesicles was raised from $200 \mu \mathrm{M}$ up to 800 $\mu \mathrm{M}$, no further enrichment was obtained. However, the oleic acid content of endothelial cells grown in lipoprotein depleted serum supplemented with high density lipoprotein and dioleoylphosphatidylcholine vesicles (method 3), was significantly increased to $30.9 \%$. Endothelial cells grown in medium 3 without dioleoylphosphatidylcholine supplementation showed fatty acid compositions similar to those of control cells. An even higher increase in oleic acid (38.8\%) was found in the membranes of endothelial cells cultured in standard culture medium supplemented with $200 \mu \mathrm{M}$ oleate (method 4). The cells showed normal morphologic appearance, von Willebrand factor staining and growth rate when cultured in these experimental media.

On the basis of these results, supplementation of standard culture medium with fatty acid sodium salts was chosen as the technique to bring about modifications in membrane fatty acyl content in further experiments.

\section{Endothelial cell membrane modification with various fatty acids}

Endothelial cells were modified using standard culture medium supplemented with various fatty acid sodium salts $(200 \mu \mathrm{M})$. The cells were cultured in these media for 7 or 8 days. Within this period, they were subcultured twice (from passage 2 or from passage 3 to 5 for frozen cells). Endothelial cells were also cultured in standard culture medium supplemented with a mixture of fatty acids $(200 \mu \mathrm{M})$ consisting of $34 \%$ $16: 0,12 \% 18: 0,34 \% 18: 1$ and $20 \% 18: 2$, which is comparable to the free fatty acid composition of human serum. The fatty acid pattern of these cells was similar to that of endothelial cells cultured in standard culture medium without fatty acid supplementation. These cells served as an additional group of control cells.

All cells showed normal morphologic appearance and normal von Willebrand factor staining. The fatty acid modified endothelial cells showed the same growth rate as control cells, except for the cells cultured in eicosapentaenoic acid $(20: 5(n-3))$ or docosahexaenoic acid $(22: 6(n-3))$ supplemented media, which occasionally exhibited a slightly reduced growth rate compared to control cells. Also, proliferation of endothelial cells as measured by bromodeoxyuridine incorporation, was not significantly influenced by fatty acid modification as shown in fig. 1. Cells modified with palmitic acid (16:0) or eicosapentaenoic acid showed a slightly but not significantly reduced proliferation.

The modifications in fatty acid compositions were not accompanied by significant changes in membrane phospholipid, cholesterol and protein contents (data not shown). This suggests that the changes in fatty acid composition are due to fatty acyl substitution in phospholipids and not to accumulation of phospholipids in the membrane. 


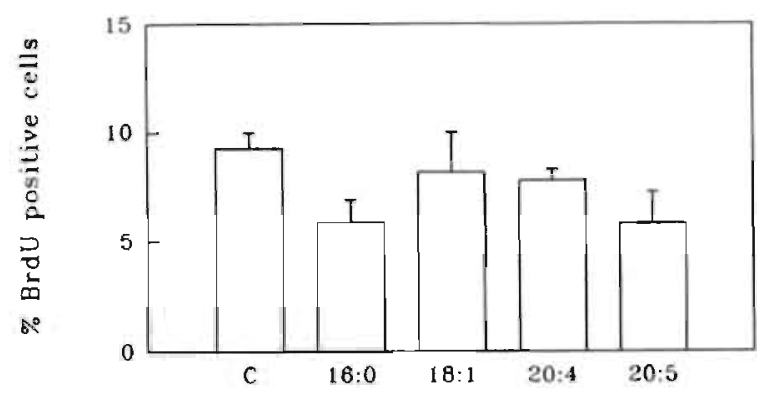

Fig. 1. Proliferation of endothelial cells modified with various fatry acids. Endothelial cells were cultured in various fatty acid modified media from passage 2 to 4 . The cells were washed and incubated with culture medium supplemented with bromodeoxyuridine (10 $\mu \mathrm{M}$ final concentration) for $30 \mathrm{~min}$. The cells were trypsinized and cytospin preparations were prepared and stained as described in materials and methods. Proliferation is expressed as percentage bromodeoxyuridine positive endothelial cells. Data are mean (SD) of 3 independent experiments. Abbreviations: C, control cells cultured without supplemented fatty acid; 16:0, 18:1, 20:4, and 20:5 are endothelial cells modified with palmitic, oleic, arachidonic, and eicosapentaenoic acid, respectively.

Table 2 shows the fatty acid compositions of endothelial cells cultured with various fatty acids. The amount of the specifically supplemented fatty acid was increased in all modified cell membranes. This was accompanied by an increase in the direct elongation products of the supplemented fatty acids, but not by an increase in their desaturation products. In addition, compensatory changes in the levels of other fatty acids occurred. For example, endothelial cells modified with eicosapentaenoic acid contained $10.5 \%$ of $20: 5$, as compared to $0.6 \%$ for control cells. The elongation product $22: 5(\mathrm{n}-3)$ was increased, whereas the desaturation product 22:6(n-3) was not increased. In fact, the increase in 20:5 was compensated primarily by a reduction in $22: 6$ from $3.5 \%$ to $0.5 \%$, and by a reduction in arachidonic acid (20:4) from $10.8 \%$ to $3.5 \%$. Similarly, an increase in linoleic acid (18:2(n-6)) content from $4.1 \%$ to $33.0 \%$ was accompanied by a reduction in the desaturation product arachidonic acid (20:4(n-6)), while the elongation product $20: 2(n-6)$ was increased from $0.7 \%$ to $5.4 \%$.

An increase in arachidonic acid content from $10.8 \%$ to $17.4 \%$ was compensated primarily by a reduction of linoleic acid $(18: 2(n-6))$, oleic acid (18:1(n-9)) and docosahexaenoic acid (22:6(n-3)). The content of the direct elongation product $22: 4(n-6)$ was again increased from $3.6 \%$ to $13.2 \%$, upon increase in arachidonic acid. 
Table II. Fatty acid composition of endothelial cells modified with various fatty acids

\begin{tabular}{|c|c|c|c|c|c|c|c|c|c|}
\hline \multicolumn{10}{|c|}{ fatty acid supplemented to culture medium } \\
\hline Farty acida & $--b$ & FA-Mix ${ }^{C}$ & $16: 0$ & $18: 0$ & 18:1 & $18: 2$ & $20: 4$ & $20: 5$ & $22: 6$ \\
\hline \multicolumn{10}{|c|}{ composition (\% of total) } \\
\hline 16:0 & $19.8 \pm 0.4$ & $20.0 \pm 0.5$ & $24.4 \pm 0.5$ & $12.2 \pm 2.4$ & $15.6 \pm 0.4$ & $17.7 \pm 0.8$ & $22.3 \pm 0.3$ & $21.7 \pm 0.6$ & $21.5 \pm 0.4$ \\
\hline 18:0 & $12.8 \pm 0.2$ & $13.6 \pm 0.1$ & $12.3 \pm 0.1$ & $22.5 \pm 1.8$ & $10.4 \pm 0.3$ & $10.9 \pm 0.3$ & $11.8 \pm 0.5$ & $13.2 \pm 0.3$ & $13.3 \pm 0.3$ \\
\hline $18: 1(n-9)$ & $18.2 \pm 0.3$ & $18.0 \pm 0.3$ & $12.7 \pm 1.0$ & $13.5 \pm 0.2$ & $38.8 \pm 0.9$ & $10.1 \pm 0.1$ & $14.4 \pm 0.2$ & $17.7 \pm 0.5$ & $17.0 \pm 0.4$ \\
\hline $18: 2(n-6)$ & $14.1 \pm 0.5$ & $15.7 \pm 0.7$ & $10.7 \pm 1.0$ & $12.5 \pm 0.4$ & $8.0 \pm 0.4$ & $33.0 \pm 0.6$ & $8.4 \pm 0.5$ & $11.1 \pm 0.6$ & $12.5 \pm 0.6$ \\
\hline $20: 2(n-6)$ & $0.7 \pm 0.2$ & $1.2 \pm 0.3$ & $0.3 \pm 0.2$ & $0.6 \pm 0.1$ & $0.5 \pm 0.2$ & $5.4 \pm 0.1$ & $0.3 \pm 0.1$ & $0.2 \pm 0.1$ & $0.6 \pm 0.2$ \\
\hline $20: 4(n-6)$ & $10.8 \pm 0.3$ & $11.6 \pm 1.0$ & $15.0 \pm 0.8$ & $16.6 \pm 0.7$ & $6.6 \pm 0.3$ & $5.7 \pm 0.2$ & $17.4 \pm 1.0$ & $3.5 \pm 0.2$ & $7.9 \pm 0.3$ \\
\hline $20: 5(n-3)$ & $0.6 \pm 0.1$ & $0.5 \pm 0.1$ & $0.6 \pm 0.1$ & $1.0 \pm 0.1$ & $0.4 \pm 0.1$ & $0.6 \pm 0.1$ & $0.1 \pm 0.03$ & $10.5 \pm 0.7$ & $1.2 \pm 0.2$ \\
\hline $22: 4(n-6)$ & $3.6 \pm 0.2$ & $4.2 \pm 0.1$ & $4.2 \pm 0.2$ & $3.0 \pm 0.3$ & $3.3 \pm 0.1$ & $3.5 \pm 0.1$ & $13.2 \pm 0.2$ & $0.6 \pm 0.1$ & $1.1 \pm 0.1$ \\
\hline $22: 5(n-3)^{d}$ & $3.0 \pm 0.3$ & $2.7 \pm 0.1$ & $3.1 \pm 0.2$ & $2.7 \pm 0.3$ & $2.3 \pm 0.2$ & $3.5 \pm 0.4$ & $0.7 \pm 0.1$ & $11.7 \pm 0.6$ & $1.5 \pm 0.4$ \\
\hline $22: 6(n-3)$ & $3.5 \pm 0.1$ & $3.4 \pm 0.1$ & $3.9 \pm 0.1$ & $4.0 \pm 0.5$ & $2.7 \pm 0.1$ & $2.1 \pm 0.2$ & $0.5 \pm 0.1$ & $0.5 \pm 0.1$ & $12.6 \pm 0.7$ \\
\hline $\begin{array}{l}\text { unsaturation } \\
\text { index }\end{array}$ & $148.2 \pm 6.3$ & $153.2 \pm 8.3$ & $156.9 \pm 9.5$ & $163.8 \pm 10.2$ & $128.9 \pm 5.8$ & $154.3 \pm 6.4$ & $172.2 \pm 7.6$ & $177.5 \pm 10.2$ & $177.8 \pm 10.8$ \\
\hline
\end{tabular}




\section{Previous page:}

Table 2. Fatty acid composition of endothelial cells modified with various fatty acids.

Endothelial cells were cultured from passage 2 or 3 to 4 or 5 in standard culture medium supplemented with various fatty acid sodium salts $(200 \mu \mathrm{M})$ as indicited. Then, cells were trypsinised, phospholipids were extracted and fatty acid compositions were determined as described in Materials and Methods. Data are mean values $\pm S D$ from $7-10$ separate cultures. Values are expressed as percentage of total fatty acids.

a A set of about 36 fatty acids were measured by GLC, but only the major fatty acids of endothelial cell phospholipids are listed. The composition of minor fatty acids did not change considerably for differently modified endothelial cells.

b Control: endothelial cells cultured without supplemented fatty acid

c FA-mix: endothelial cells cultured in standard culture medium supplemented with a fatty acid mixture $(200 \mu \mathrm{M})$ comparable to the free fatty acid composition of human serum $(35 \% 16: 0,12 \% 18: 0,34 \% 18: 1$ and $20 \% 18: 2)$

d 22:5(n-3) is not completely separated from $24: 2(n-6)$

e The unsaturation index is calculated by summation of the percentage of each fatty acid in a sample multiplied by the number of double bonds contained in that fatty acid

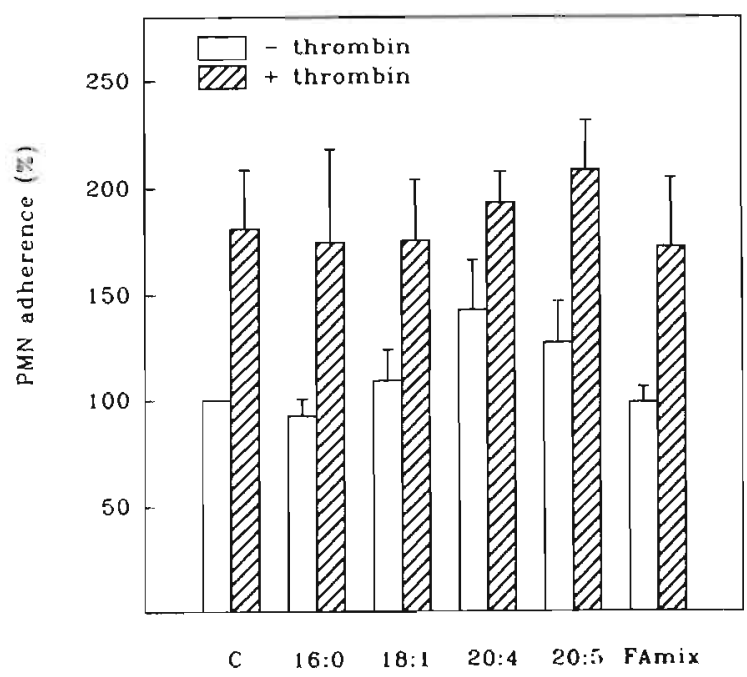

Fig. 2. Polymorphonuclear leukocyte adherence of endothelial cells modified with various fatry acids. Endothelial cells (ECs) were cultured in various fatty acid modified media from passage 2 or 3 to 4 or 5 . ECs were incubated with or without thrombin (1 $\mathrm{U} / \mathrm{ml}$ ) for $20 \mathrm{~min}$. Then, the cells were washed and incubated with polymorphonuclear leukocytes (PMNs) for $15 \mathrm{~min}$. After washing and staining the adherend PMNs and ECs were counted (see Materials and Methods). PMN adherence is expressed as percentage of control (PMN adherence to unstimulated control cells is 100\%). Each bar is the mean (SD) of 5 separate cultures. Abbreviations as in fig. 1. FAmix, endothelial cells modified with a fatty acid mixture of a composition comparable to the free fatty acid composition of human serum 
Adherence of polymorphonuclear leukocytes and monocytes to fatty acid modified endothelial cells

In order to investigate the influence of the fatty acid composition of endothelial cell membranes on polymorphonuclear leukocyte adherence, several fatty acid modified endothelial cells, either unstimulated or prestimulated with thrombin $(1 \mathrm{U} / \mathrm{ml}$ for $20 \mathrm{~min})$, were incubated with human polymorphonuclear leukocytes for $15 \mathrm{~min}$. For unstimulated endothelial cells, polymorphonuclear leukocyte adherence to cells modified with the unsaturated fatty acids oleic acid, arachidonic acid or eicosapentaenoic acid, was only slightly but not significantly increased compared to polymorphonuclear leukocyte adherence to control cells as is shown in fig. 2. After stimulation of endothelial cells with thrombin, polymorphonuclear leukocyte adherence was increased for all endothelial cells without revealing significant differences between the differently modified endothelial cells. Comparable results were found for adherence of monocytes to fatty acid modified endothelial cells (data not shown).

\section{Procoagulant activity of fatty acid modified endothelial cells}

The procoagulant activities of various fatty acid modified endothelial cells (nonstimulated or thrombin stimulated) are shown in fig. 3 . Compared to control cells, all nonstimulated fatty acid modified cells showed a slight prolongation in clotting time, indicating some decrease in procoagulant activity of endothelial cells modified with palmitic, oleic, arachidonic or eicosapentaenoic acid. After prestimulation of endothelial cells by thrombin $(1 \mathrm{U} / \mathrm{ml})$, clotting times decreased to about the same extent for all cells, indicating an increase of endothelial cell procoagulant activity due to thrombin stimulation. The slight influence of fatty acid composition on endothelial cell procoagulant activity, thus, disappeared after thrombin stimulation.

Fig. 4 shows the reduction in clotting time of human plasma induced by various amounts of human brain thromboplastin. In this conventional clotting assay already a very small amount of thromboplastin $\left(10^{-4}\right.$ units) reduced the plasma clotting time from 400 to 300 seconds. This indicates that the changes in clotting times of the nonstimulated fatty acid modified endothelial cells are probably of minor importance.

\section{Eicosanoid production by fatty acid modified endothelial cells}

In order to investigate the influence of endothelial cell membrane fatty acid composition on eicosanoid production, several fatty acid modified endothelial cells were stimulated with thrombin and the eicosanoids produced were measured in the cell supernatants. Table 3 shows the eicosanoid spectrum produced by various fatty acid modified endothelial cells. The main eicosanoids measured by high performance liquid 


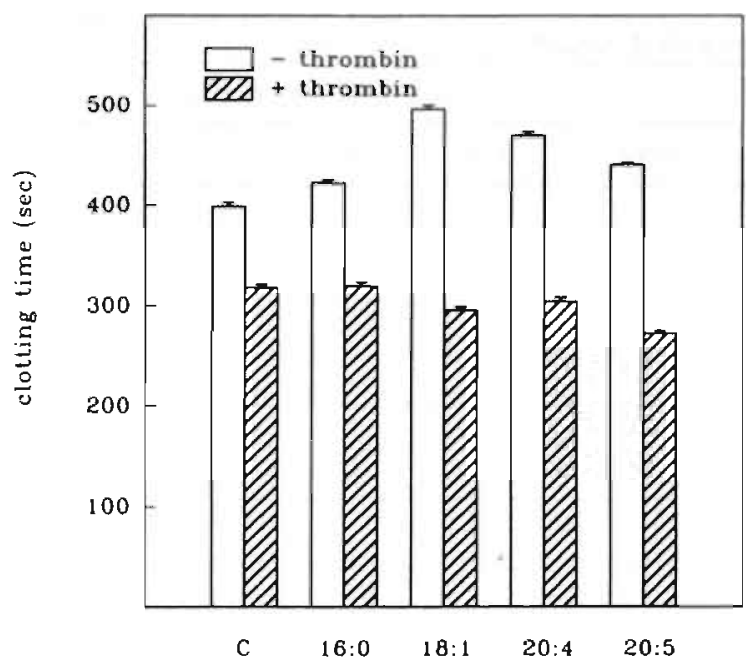

Fig.3. Procoagulant activity of endothelial cells modified with various fatty acids. Endothelial cells were cultured in various fatty acid modified media from passage 2 or 3 to 4 of 5 . The cells were incubated with or without thrombin $(1 \mathrm{U} / \mathrm{ml})$ for $20 \mathrm{~min}$. Then, cell monolayers were washed and incubated with human plasma/Michaelis buffer $(1: 1$, $\mathrm{v} / \mathrm{v})$ for $15 \mathrm{~min}$ at $37^{\circ} \mathrm{C}$. Then, $\mathrm{CaCl}_{2}(0.033 \mathrm{M})$ was added and clotting times were measured (see Materials and Methods). The procoagulant activity is expressed as seconds of clotting time: a decrease in clotting time indicates an increase in procoagulant activity of the cells. Each bar is the mean of 6 clotting time measurements from a representative experiment of 5 so performed. Abbreviations are as in Fig.1.

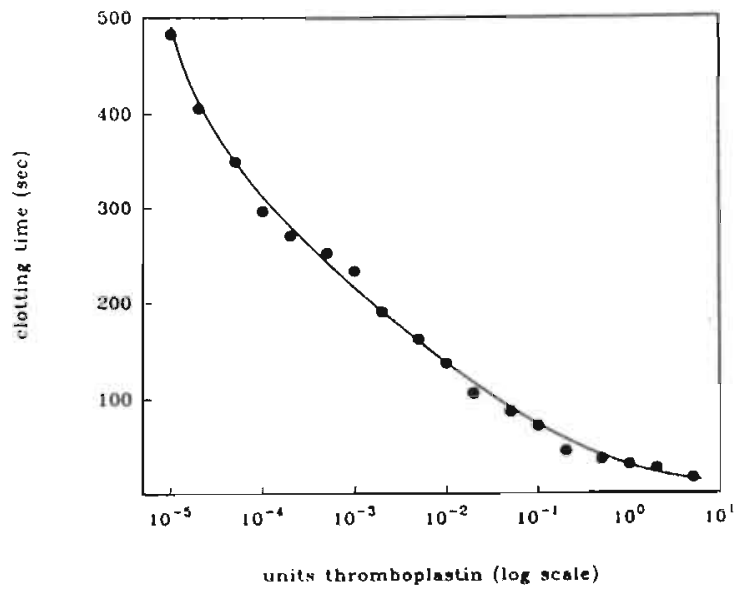

Fig.4. Influence of human brain thromboplastin on the clotting time of normal human plasma. Various amounts of a human brain thromboplastin preparation were incubated with normal human plasma/Michaelis buffer $(\mathrm{pH} 7.4)(1: 1, \mathrm{v} / \mathrm{v})$ and $\mathrm{CaCl}_{2}(0.033 \mathrm{M})$ at $37^{\circ} \mathrm{C}$ and clotting times were measured. Arbitrary, 1 Unit is defined as the amount of thromboplastin corresponding to a clotting time of 31.8 seconds. 
Table 3. Eicosanoid spectrum produced by fatty acid modified endothelial cells after stimulation with thrombin.

\begin{tabular}{lrrrrrr}
\hline & \multicolumn{7}{c}{ supplemented fatty acid } \\
\cline { 2 - 7 } Eicosanoids & none & $16: 0$ & $18: 1$ & $20: 4$ & $20: 5$ & Fa-mix \\
\hline 6-keto PGF 1a & 225 & 30 & 61 & 368 & 40 & 167 \\
PGF2a & 247 & 127 & 163 & 652 & 92 & 224 \\
PGFE2 & 26 & 7 & 11 & 16 & -- & 20 \\
TxB2 & -- & -- & -- & 102 & -- & 12 \\
\hline \multirow{2}{*}{ Total } & 498 & 164 & 235 & 1138 & 132 & 423 \\
\hline
\end{tabular}

Endothelial cells obtained from one umbilical cord were cultured in various fatty acid modified media from passage 2 to 4 . The cells were washed and stimulated with thrombin $(1 \mathrm{U} / \mathrm{ml}$ for $15 \mathrm{~min})$. The eicosanoids were measured in the cell supernatants by high performance liquid chromatography (see Materials and Methods). Values are expressed as pmol eicosanoid/5.106 endothelial cells

Table 4. Total eicosanoid production of endothelial cells modified in arachidonic acid content with various fatty acids

\begin{tabular}{crrrrrr}
\hline Isolation & \multicolumn{6}{c}{ supplemented fatty acid } \\
\cline { 2 - 7 } number & $20: 5$ & $18: 1$ & none & FA mix & $16: 0$ & $20: 4$ \\
\cline { 2 - 7 } & \multicolumn{7}{c}{ total eicosanoids $\left(\mathrm{pmol} / 5.10^{6}\right.$} & $\mathrm{ECs})$ \\
1 & $\mathrm{ND}$ & 351 & 631 & $\mathrm{ND}$ & 1386 & 373 \\
2 & 40 & 395 & 872 & 934 & $\mathrm{ND}$ & 379 \\
3 & 397 & 950 & 933 & $\mathrm{ND}$ & 1640 & 820 \\
4 & 37 & 104 & 150 & 92 & 105 & 712 \\
5 & 132 & 235 & 498 & 423 & 164 & 1138 \\
6 & 27 & 63 & 95 & 76 & 54 & 689 \\
7 & 118 & 22 & 450 & $\mathrm{ND}$ & 127 & 358 \\
\hline arachidonic & $3.5 \pm 0.2$ & $6.6 \pm 0.3$ & $10.8 \pm 0.3$ & $11.6 \pm 1.0$ & $15.0 \pm 0.8$ & $17.4 \pm 1.0$ \\
acid & \multicolumn{7}{c}{}
\end{tabular}

Endothelial cells were cultured in various fatty acid modified media from passage 2 or 3 to 4 or 5 . The cells were washed and incubated with thrombin for $15 \mathrm{~min}$. Supernatants were collected and eicosanoids were measured (see Material and Methods). The total amounts of eicosanoids produced by fatry acid modified cells are tabulated for increasing endogenous arachidonic acid content. Values are obtained from cultures of 7 different isolations as indicated 
chromatography were prostaglandin $F_{2 \alpha}$, 6-keto prostaglandin $F_{1 \alpha}$ (the stable metabolite of prostacyclin), prostaglandin $\mathrm{E}_{2}$ and thromboxane $\mathrm{B}_{2}$. The eicosanoid spectrum was relatively similar in all experiments, but the total amount of eicosanoids produced varied between endothelial cell populations obtained from different umbilical veins. This is illustrated in table 4.

The results summarized in table 4 show that lowering of the endogenous arachidonic acid content relative to control cells - as was obtained by culturing endothelial cells in 20:5 and 18:1 supplemented media - was associated with a decrease in total eicosanoid production. A higher amount of endogenous arachidonic acid seemed to give rise to an increase in total eicosanoid production, however, no firm conclusion can be drawn here, because of the relatively large variation in the experimental data.

\section{Discussion}

The results of this study show that the fatty acid composition of cultured endothelial cells can be extensively modified in a standardized way, while the cells show normal morphologic appearance, growth characteristics and proliferation. This opens the possibility to study the influence of endothelial cell membrane fatty acid composition on various endothelial cell functional properties.

Alterations in endothelial fatty acid composition were induced by culturing the cells in different culture media (table 1). It can be seen in table I that the fatty acid composition of endothelial cells cultured in standard culture medium supplemented with human serum and dioleoylphosphatidylcholine vesicles did not change significantly. The reason for this might be that, although cultured cells can take up phospholipids from unilamellar vesicles [9], the presence of serum or dialysed serum probably results in degradation of the vesicles [19]. A different result is obtained in the presence of lipoproteins. When high density lipoprotein is incubated with dioleoylphosphatidylcholine vesicles before addition to serum, high density lipoprotein might catalyze exchange or uptake of phospholipids from the vesicles [20] and, by subsequent interaction with endothelial cells [21], modify their fatty acid composition.

The fatty acid composition of endothelial cell membranes can be modified most efficiently by culturing endothelial cells in media supplemented with various fatty acids. Addition of $200 \mu \mathrm{M}$ fatty acids to the culture medium by itself does not influence endothelial cell growth and functional properties, as is shown by the results of culturing endothelial cells in the presence of a fatty acid mixture that does not affect 
membrane fatty acid composition. The present method differs from that described earlier by Spector et al. [22] in that the endothelial cells were not only incubated with the fatty acid modified media (as in the experiments of Spector) but also trypsinized and subcultured in these media for 7 or 8 days to investigate if they still showed normal growth characteristics and morphologic appearance under long term equilibrium conditions.

The results of fatty acid modification (table 2) show that not only the membrane content of the specifically added fatty acid was increased, but also that of its direct elongation product. However, there was no indication that the cells converted linoleic acid into arachidonic acid. This observation was reported earlier for bovine aortic endothelial cells [22]. An explanation may be the relatively high serum content of the culture media; Rosenthal et al. [23] reported suppression of $\Delta 6$ desaturase activity when the serum content of the culture medium was increased from $2.5 \%$ to $20 \%(\mathrm{v} / \mathrm{v})$. The cultured endothelial cells do not appear to convert eicosapentaenoic acid into docosahexaenoic acid either, which indicates that endothelial cells express a very low $\Delta 6$ and $\Delta 4$ desaturase activity when grown in serum containing fatty acid rich media.

There is also a variation in the extent to which different fatty acids can be increased. For example, supplementation of culture media with palmitic acid or stearic acid increased the phospholipid 16:0 or 18:0 content respectively and total saturated fatty acid content by only a small amount. For the unsaturated fatty acids, however, a large increase was found. This is presumably due to a higher tumover rate of unsaturated fatty acids at the sn- 2 position, caused by endogenous phospholipase $\mathrm{A}_{2}$ activity and preferential incorporation of unsaturated fatty acids at the sn2 position of phospholipids [22,29].

Supplementation of culture media with the polyunsaturated fatty acids arachidonic, eicosapentaenoic or docosahexaenoic acid resulted in a large increase of these fatty acids in endothelial cell phospholipids at the expense of $22: 6$ and $18: 2,20: 4$ and $22: 6$, or $20: 4$ respectively. The unsaturation indexes were also increased compared to control cells. The total amount of polyunsaturated fatty acids, however, remained rather similar to that of control cells, which indicates that increases in polyunsaturated fatty acids are compensated primarily by decreases in other polyunsaturated fatty acids or by a decrease in the monounsaturated $18: 1$, as can be seen in table 2. However, an enrichment in oleic acid was accompanied by a decrease in polyunsaturated fatty acids as well as saturated fatty acids. This suggests that 18:1 may replace both unsaturated fatty acids at the sn- 2 position and saturated fatty acids at the sn- 1 position of phospholipids.

Enrichment of endothelial cell membranes with polyunsaturated fatty acids resulted in a decrease in arachidonic acid content, whereas enrichment with arachidonic acid itself produced an increase in the arachidonic acid content. Unexpectedly, enrichment with saturated fatty acids also 
produced an increase in the arachidonic acid content. A similar phenomenon has been observed for platelets of dietary manipulated rats [24]. In contrast, Spector and Yorek [9] reported no change in arachidonic acid content of palmitic acid treated bovine endothelial cells compared to control cells. This may be due to their relatively short incubation time with palmitic acid enriched medium [22] compared to our in vitro culture method.

Variations in polyunsaturated fatty acid content may influence the production of eicosanoids and thereby the exchange of local mediators between cells involved in haemostatic and inflammatory processes. In view of the importance of the interaction between endothelial cells and the humoral and cellular phases of blood, the first endothelial cell parameters studied were adherence of polymorphonuclear leukocytes and monocytes to endothelial cells, endothelial cell procoagulant activity and eicosanoid production. The results of polymorphonuclear leukocyte adherence to modified endothelial cells indicate that the fatty acid composition of endothelial cell membranes hardly influences polymorphonuclear leukocyte adherence to either nonstimulated or thrombin stimulated endothelial cells. Comparable results were found for monocyte adherence. In response to thrombin stimulation polymorphonuclear leukocyte adherence increased and endothelial cell contraction was observed, a phenomenon also reported by others [25,26]. Zimmerman et al. [30] showed that this effect of thrombin is exerted via the endothelial cells, possibly via enhancement of platelet activating factor production and induction or exposure of endothelial adherence receptors.

The results of determinations of endothelial cell procoagulant activity indicate that the fatty acid composition of endothelial cell membranes influences the clotting time of nonstimulated cells to a slight extent. Prestimulation of cells with thrombin abolished these differences. A similar phenomenon has been observed for the influence of dietary fatty acyl manipulation on the procoagulant activity of rat peritoneal macrophages [27]. Since the amount of tissue factor exposed on the membrane increases upon stimulation [28], subtle differences in procoagulant activity between the various nonstimulated endothelial cells are no longer obvious. Apparently, there is no change in thromboplastin exposure upon altering the fatty acid composition of the membrane. Another explanation would be that clotting times were decreased by thrombin that remained bound to the endothelial surface, thereby abolishing subtle pre-existing differences in procoagulant activity.

Measurements of the eicosanoid spectrum of thrombin stimulated endothelial cells showed a relatively low production of 6-keto-prostaglandin $F_{1 \alpha}$ (table 3 ). This may be due to the effect of subcultivation: subcultured endothelial cells show a decreased production of 6-ketoprostaglandin $F_{1 \alpha}$ compared to primary endothelial cultures [31]. The results of measurements of endothelial cell eicosanoid production (table 4) 
suggest an association between a lowering in arachidonic acid content of endothelial cell membranes and a decrease in eicosanoid production upon stimulation by thrombin, as could be expected [9]. The large variation in data from cells with increased amounts of endogenous arachidonic acid, however, do not permit a firm conclusion. There is no straightforward explanation for the observation of differently responding endothelial cell populations. Apparently several parameters affect the process of eicosanoid production; in addition to the availability of endogenous arachidonic acid, the susceptibility to stimulation of various endothelial cell populations seems to interfere. Differences in susceptibility to stimulation may have several causes, for instance interindividual differences between umbilical veins. It was also observed that, generally speaking, endothelial cells which had been previously frozen $\left(-70^{\circ} \mathrm{C}\right.$, after the first passage) showed a higher eicosanoid production upon thrombin stimulation than the unfrozen cells which were used for fatty acid modification immediately after the first passage.

In conclusion, these results indicate that considerable changes in membrane fatty acid composition of cultured endothelial cells affect arachidonic acid metabolism. It is surprising, however, that dramatic alterations in fatty acid composition - far beyond those which can be attained by dietary means - hardly influence endothelial cell functional properties like cellular procoagulant activity and adherence of polymorphonuclear leukocytes and monocytes: apparently 'homeostasis' is also important at the level of endothelial cell functional activity. These studies do not exclude that the availability of arachidonic acid for the formation of local mediators can have important consequences for the exchange of local mediators between cells during haemostasis and inflammatory processes.

\section{Acknowledgement}

The authors wish to thank for their excellent technical assistance: Jos Stegen and Marianne Simonis for gas-liquid chromatography, Puck Muller for procoagulant activity assay, Wil Mullers for polymorphonuclear leukocyte adhesion assay, Jorike Endert for eicosanoid analysis, and Hera Lichtenbeld for proliferation assay. Appreciation also goes to the department of Medical Microbiology (University of Limburg, Maastricht) for assistance with cell culture, the department of Obstetrics and Gynaecology (The Wever Hospital, Heerlen) for supply of umbilical cords and the Red Cross Bloodbank Limburg (Maastricht) for supply of human serum.

\section{References}

1 Gimbrone, M.A. 1986.Vascular endothelium: nature's blood container. in: Vascular endothelium in hemostasis and thrombosis (Gimbrone, M.A., ed.), Churchill Livingstone inc., New York, pp 1-13 
2 DiCorletto, P.E., and Chisolm, G.M. 1986. Participation of the endothelium in the development of the atherosclerotic plaque. Prog. Lipid Res. 25, 365-374

3 Nordoy, A. 1985. Dietary fatty acids, platelets, endothelial cells and coronary heart disease. Acta Med. Scand. 701, 15-22

4 Goodnight, S.H. 1988. Effects of dietary fish oil and omega-3 fatty acids on platelets and blood vessels. Seminars in Thrombosis and Hemostasis 14, 285-289

5 Rand, M.L., Hennissen, A.A.H.M., and Hornstra, G. 1986. Effects of dietary sunflowerseed oil and marine oil on platelet membrane fluidity, arterial thrombosis, and platelet responses in rats. Atherosclerosis 62, 267-276

6 Lagarde, M., Sicard, B., Guichardant, M., Felici, O., and Dechavanne, M. 1984. Fatty acid composition in native and cultured human endothelial cells in Vitro 20,33-37

7 Periago, J.L., De Lucchi, C., Gil, A., Suárez, M.D., and Pita, M.L. 1988. Lipid composition of liver microsomes in rats fed a high monounsaturated fatty acid diet. Biochim. Biophys. Acta $962,66-72$

8 Stubbs, C.D., and Smith, A.D. 1984. The modification of mammalian membrane polyunsaturated fatty acid composition in relation to membrane fluidity and function. Biochim. Biophys. Acta 779, 89-137

9 Spector, A.A., and Yorek, M.A. 1985. Membrane lipid composition and cellular function. J. Lipid Res. 26, 1015-1035

10 Hagve, T.A. 1988. Effects of unsaturated fatty acids on cell membrane functions. Scand. J. Clin. Lab. Invest. 48, 381-388

11 Maciag, T., Cenundole, I., Istey, S., Kelly, P.R., and Foriand, R. 1979. An endothelial cell growth factor from bovine hypothalamus: identification and partial characterization. Proc. Nat. Acad. Sci. USA 76, 5674-5678

12 Terpstra, A.H.M., Woodward, C.J.H., and Sanches-Muniz, F.J. 1981, Improved techniques for separation of serum lipoproteins by density gradient ultracentrifugation: visualization by prestaining and rapid separation of serum lipoproteins trom small values of serum. Biochem. $111,149-157$

13 Astaldi, G.C.B., Janssen, M.C., Lansdorp, P.M., Willems, Ch., Zeijlemaker, W.P., and Oosterhol, F. 1980. Human endothelial culture supernatant (HECS): a growth factor for hybridomas. J. Immunol. 125, 1411-1414

14 Bligh, E.G., and Dyer, W.J. 1959. A rapid method for total lipid extraction and purification. Can. J. Biochem. Physiol. 37, 911-917

15 Böttcher, C.J.F., Gent, C.M. van, and Pries, C. 1961. A rapid and sensitive sub-micro phosphorus determination. Anal. Chim. Acta 24, 203-204

16 Span, A.H.M., Schijns, N.L.F., Boven, C.P.A. van, and Bruggeman, C.A. (1989) Eur. J. Clin. Med.Invest. 19, 542-548

17 Muller, A.D., Dam-Mieras, M.C.E. van, and Hemker, H.C. 1985. Measurement of macrophage cellular procoagulant activity. Haemostasis 15, 108-113

18 Engels, W., Kamps, M.A.F., Lemmens, P.J.M.R., Vusse, G.J. van der, and Reneman, R.S. 1988. Determination of prostaglandins and thromboxane in whole blood by highperformance liquid chromatography with fluorimetric detection. J. Chromalogr. 427, 209218

19 Pagano, R.E., and Huang, L. 1975. Interaction of phospholipid vesicles with cultured mammalian cells: studies of mechanism. J. Cell. Biol. 67, 49-60

20 Damen, J., Dijkstra, J., Regts, J., and Scherphof, G. 1980. Effect of lipoprotein-free serum on the interaction of human plasma high density lipoprotein with egg yolk phosphatidylcholine liposomes. Biochim. Biophys. Acta 620, 90-99

21 Tauber, J.P., Goldminz, D., Vlodawsky, J., and Gospodarowicz, D. 1981. The interaction of the high-density lipoprotein with cultured cells of bovine vascular endothelium. Eur. J. Biochem. 119, 317-325

22 Spector, A.A., Kaduce, T.L., Hoak, J.C., and Fry, G.L. 1981. Utilization of arachidonic and linoleic acids by cultured human endothelial cells. J. Clin. Invest. 68: 1003-1011

23 Rosenthal, M.D., and Whitehurst, M.C. 1983. Fatty acid $\Delta^{6}$ desaturation activity of cultured human endothelial cells: modulation by fetal bovine serum. Biochim. Biophys. Acta 750 , 490-496

24 Heemskerk, J.W.M., Feijge, M.A.H., Kalafusz, R., and Hornstra, G. 1989. Influence of dietary fatty acids on membrane fluidity and activation of rat platelets. Biochim. Biophys. Acta $1004,252-260$

25 Pollock, W.K., Wreggett, K.A., and Irvine, R.F. 1988. Inositol phosphate production and $\mathrm{Ca}^{2+}$ mobilization in human umbilical vein endothelial cells stimulated by thrombin and histamine. Biochem. J. 256, 371-376 
26 Goligorsky, M.S. Menton, D.N., Laszlo, A., and Lum, H. 1989. Nature of thrombin-induced sustained increase in cytosolic calcium concentration in cultured endothelial cells. J. Biol. Chem. 264, 16771-16775

27 Dam-Mieras, M.C.E. van, Muller, A.D., and Hornstra, G. 1985. Dietary lipids, infection and macrophage procoagulant activity. 13th International Congres of Biochemistry Amsterdam, The Netheriands, Abstract

28 Bertina, R.M., Besselaar, A.M.H.P. van den, and Bom, V.J.J. 1989. Tissue thromboplastin and the initiation of coagulation. in: Coagulation and Lipids (Zwaal R.F.A., ed.) CRC, Elsevier, Amsterdam

29 Deenen, L.L.M. van, and Haas, G.H. de 1966. Phosphoglycerides and phospholipases. Ann. Rev. Biochem. 35, 157-194

30 Zimmerman, G.A., Mclntyre, T.M., and Prescott, S.M. 1986. Thrombin stimulates neutrophil adherence by an endothelial cell-dependent mechanism: characterization of the response and relationship to platelet-activating factor synthesis. Annals New York Academy of Sciences 485, 349-368

31 Ingerman-Wojenski, C.M., Silver, M.J., Mueller, S.N., and Levine, E.M. 1988. Prostacyclin synthesis by endothelial cells from human umbilical veins: effect of cumulative population doublings. Prostaglandins 36, 127-137

32 Lichtenbeld, H.C., and Blijham, G.H. 1992. Tumor cell spheroids induce a mitogenic response in endothelial cells. in: Angiogenesis: Key Principles-Science-TechnologyMedicine. (Steiner, R., Weisz, P.B., Langer, R. eds.) Birkhauser Verlag, Basel, pp 261-265 


\section{Chapter 3}

Long-term Fatty Acid Modification of Endothelial Cells:

Implications for Arachidonic Acid Distribution in Phospholipid Classes

Renée C.R.M. Vossen, Marion A.H. Feijge, Johan W.M. Heemskerk, Maria C.E. van Dam-Mieras, Gerard Hornstra, Robert F.A. Zwaal. 


\section{Abstract}

Human umbilical vein endothelial cells were cultured in various fatty acid modified media until equilibrium conditions were reached (7-8 days). The effects on the fatty acid composition of phospholipid classes and on the metabolism of arachidonic acid (20:4(n-6)) were studied. The results showed that in every phospholipid class large changes in fatty acid composition, including 20:4(n-6) content, were induced by long-term modification with unsaturated as well as saturated fatty acids. However, the mean levels of saturated and unsaturated fatty acids per phospholipid class remained relatively constant, except for cells modified with oleic acid, which showed an increase in monounsaturated fatty acids at the expense of both saturated and polyunsaturated fatty acids.

The rate of incorporation of radiolabeled 20:4(n-6) in endothelial lipids was not influenced by long-term fatty acid modification. Cells modified with 20:4(n-6) (having a high 20:4(n-6) content) tended to "store" excess $20: 4(n-6)$ as the elongated product $22: 4(n-6)$ mainly into phosphatidylserine and ethanolamine phospholipid. On the other hand, endothelial cells modified with 20:5(n-3) (having a low 20:4(n-6) content) differed typically from other fatty acid modified cells by a relatively high level and high incorporation rate of $20: 4(n-6)$ in phosphatidylinositol, with a low extent of elongation.

These results indicate extensive 'homeostatic' control of membrane unsaturation in each phospholipid class and economical control of 20:4(n6) content in all modified endothelial cells, irrespective of a considerable variation of $20: 4(n-6)$ levels in cellular lipids. Moreover, the observed maintenance of a critical level of 20:4(n-6) in phosphatidylinositol, when 20:4(n-6) supply was strongly decreased, may be important for maintaining proper signal transduction upon endothelial cell stimulation. 


\section{Introduction}

Endothelial cells are actively involved in the maintenance of vascular tone and in providing selective permeability and an antithrombotic surface [1]. The endothelial membrane phospholipids and their fatty acyl moieties play a role in these processes by controlling the physico-chemical properties of the membrane [2,3] and by providing precursors for bioactive mediators such as eicosanoids and platelet activating factor upon cell stimulation $[4,5]$. However, derailment of normal endothelial function may contribute to the pathogenesis of atherosclerosis [6]. In this respect, the type of dietary lipid, which influences cellular fatty acid composition, may play a role [2]. Insight into the relationship between endothelial fatty acid composition and the functional responses of these cells may contribute to understanding a relation between the type of dietary lipids and the incidence of cardiovascular disease.

Membrane phospholipids of endothelial cells contain relatively large amounts of arachidonic acid (20:4(n-6), which can be mobilized from the phospholipids by phospholipases and subsequently converted into bioactive eicosanoids upon cell stimulation [2,7]. Despite the established central role of 20:4(n-6) in cell activation, endothelial cells acquire it mainly from exogenous sources [4]. By dietary modification, changes in membrane 20:4(n-6) content of endothelial cells can be induced. This may influence cellular responsiveness. Previous studies have shown that considerable changes in fatty acid composition can be induced in endothelial cells in vitro $[3,4,8]$. Indeed a relation between the extent of modification of the 20:4(n-6) content of total phospholipids and eicosanoid release upon stimulation was found.

Several studies [5,10-18] have described the rapid incorporation of radiolabeled 20:4(n-6) in endothelial cell phospholipids after relatively short incubation periods (5 minutes to 24 hours). In addition, other studies have shown that the time scale to reach equilibrium conditions for the distribution of radiolabeled 20:4 (n-6) over the various phospholipid classes and for the elongation and desaturation processes was much longer $[19,20,21]$. However, the effect of long-term modification with different fatty acids in vitro on endothelial fatty acid composition and 20:4(n-6) metabolism was not investigated. Insight in the extent of fatty acid modification induced by various fatty acids and the influence of these modifications on the $20: 4(n-6)$ content of the individual phospholipid classes is of importance, considering the specific roles of different phospholipid classes upon cell stimulation [2,9].

In this study human endothelial cells were modified with saturated, monounsaturated and polyunsaturated fatty acids, by long-term culture in various fatty acid modified media until equilibrium conditions were reached (7-8 days). The fatty acid compositions of each phospholipid class 
were analyzed. Furthermore, the influence of long-term fatty acid modification on the incorporation, redistribution and modification of [1${ }^{14} \mathrm{C}$ ]arachidonic acid into endothelial cell phospholipid classes was studied after both short incubation ( 2 hours) and prolonged culture ( 3 days) with radiolabeled $20: 4(n-6)$. The results indicate considerable alterations of 20:4(n-6) levels in every phospholipid class of long-term fatty acid modified endothelial cells. This may account for the observed variation in eicosanoid production of these cells [8]. Nevertheless, in every phospholipid class extensive 'homeostatic' control of membrane unsaturation and economical control of the 20:4(n-6) content was found. As was shown in $20: 5(n-3)$ modified cells with a low 20:4(n-6) content, a critical 20:4(n-6) level appeared to be maintained in phosphatidylinositol. This may be important for maintaining proper signal transduction upon endothelial cell stimulation and it may explain why the observed functional cellular reactivity remains virtually unaltered [8] despite the gross changes in fatty acid patterns.

\section{Materials and Methods}

Culture media M199 and RPMI 1640 (with L-glutamine and 20 mM HEPES) and $2.5 \%(w / v)$ trypsin solution were obtained from Flow Lab (Bioggio, Switzerland). $60 \mathrm{~cm}^{2}$ (F3003) Tissue culture dishes were from Falcon (Etten Leur, The Netherlands). EDTA, HEPES and L-glutamine were obtained from Serva (Heidelberg, Germany). Free fatty acids and their sodium salts were obtained from Sigma (St. Louis, MO, USA). All organic solvents were purchased from Merck (Darmstadt, Germany) and contained butylated hydroxy toluene $\left(50 \mathrm{mg} / \mathrm{L}\right.$, Sigma) as antioxidant. $\left[1-{ }^{14} \mathrm{C}\right]$ arachidon acid $(54.4 \mathrm{mCi} / \mathrm{mmol})$ was obtained from Amersham (Houten, The Netherlands). All chemicals used were of the highest grade of purity available.

Several buffers were used: phosphate buffered saline contained $0.137 \mathrm{M}$ $\mathrm{NaCl}, 2.6 \mathrm{mM} \mathrm{KCl}, 8.1 \mathrm{mM} \mathrm{Na} \mathrm{HPO}_{4}, 1.15 \mathrm{mM} \mathrm{KH} \mathrm{PO}_{4}$ (pH 7.4). Trypsin solution contained $0.125 \%(\mathrm{w} / \mathrm{v})$ trypsin in phosphate buffered saline containing EDTA (0.33 mM). The standard culture medium consisted of $20 \%$ human serum in M199/RPMI1640 (1:1, v/v) supplemented with L-glutamine ( $2 \mathrm{mM}$ ), gentamicin $(50 \mathrm{mg} / \mathrm{ml}), \mathrm{NaHCO}_{3}(11.9 \mathrm{mM})$ and endothelial cell growth supplement $(100 \mu \mathrm{g}$ protein $/ \mathrm{ml})$. Endothelial cell growth supplement was prepared from bovine brain as described by Maciag et al. [22].

\section{Endothelial cell culture and modification of the fatty acid composition}

Human umbilical vein endothelial cells were isolated from umbilical cord veins and cultured in standard culture medium containing 20\% human serum (pool of at least 200 healthy donors) as described previously [8]. For modification of the endothelial cell fatty acid composition, the cells were cultured in various fatty acid supplemented media from passage 2 to 4 (7 or 8 days). The fatty acid supplemented media ( $200 \mu \mathrm{M}$ final concentration) were prepared by addition of a particular fatty acid sodium salt to warm human serum $\left(37^{\circ} \mathrm{C}\right)$ prior to addition 
of culture medium as described previously [8]. In each experiment, unmodified endothelial cells were always compared to a set of 4 differently fatty acid modified cells, obtained from the same umbilical cord.

\section{Lipid analysis}

Endothelial cell mopolayers were washed twice with cold phosphate buffered saline $\left(4^{\circ} \mathrm{C}\right)$. The cells were trypsinised and washed twice with cold phosphate buffered saline containing $1.35 \mathrm{mM}$ EDTA $\left(4^{\circ} \mathrm{C}\right)$, counted with a coulter counter and frozen $\left(-20^{\circ} \mathrm{C}\right)$ untill use (within two weeks). Preliminary experiments showed no appreciable differences between total fatty acid compositions of trypsinised and scraped endothelial cells.

For lipid analysis, the cells were thawed rapidly and the lipids were extracted according to Bligh and Dyer [23]. Aliquots were taken to quantify phospholipid content by measuring phosphorus content according to Böttcher et al. [24] and to quantify cholesterol content using reagents provided by a kit (free cholesterol 310328, Boehringer, Mannheim, Germany). The lipid extract was subjected to thin-layer chromatography (TLC) and gas-liquid chromatography (GLC) as described below.

Total phospholipids were separated from neutral lipids by TLC on silicagel 60 plates (Merck) as described by Rand et al. [25]. Phospholipid classes were separated by TLC as described by Touchstone et al. [26]. Lipid bands comigrating with known standards were visualized by spraying with $0.5 \%(\mathrm{w} / \mathrm{v})$ 8-anilino-1-naphtalene sulphonic acid in methanol and UV detection. Appropriate bands were scraped and phospholipids were extracted with methanol/chloroform/water $(90: 10: 2, \mathrm{v} / \mathrm{v})$. Phosphorus content was quantified and fatty acids were methylated, extracted and analysed by GLC as described by Rand et al. [25] with some modifications: a Perkin Elmer autosystem capillary gaschromatograph with a CP-sil 5 CB column (Chrompack, Middelburg, The Netherlands) was used with 19:0 as internal standard. Data were collected and analysed using a turbochrome II workstation (Perkin Elmer, Gouda, The Netherlands)

Plasmalogen EP was separated from diacyl EP by TLC. The TLC plate was subjected to $\mathrm{HCl}$ fume for $15 \mathrm{~min}$. to hydrolyse the aldehyde moiety of plasmalogen EP, prior to development in chloroform/methanol/water $65: 25: 4$, $\mathrm{v} / \mathrm{v}$ ). Thereby diacyl EP was separated from the lyso EP formed. Thus, only the fatty acids of the sn-2 position of plasmalogen EP were analysed. Appropriate bands were scraped and analysed as described above.

\section{Labeling of endothelial cells with $\left[1-{ }^{14} \mathrm{C}\right]$ arachidonate and lipid analysis of radiolabeled cells}

Endothelial cells were cultured from passage 2 to 4 in fatty acid modified media. Subconfluent modified endothelial cells (passage 4) were cultured for 3 days in the same media supplemented with $0.625 \mu \mathrm{Ci}$ sodium [1-14C]arachidonate $(2.3 \mu \mathrm{M})$. In a parallel experiment, confluent modified endothelial cells (passage 4) were incubated for 2 hours with $0.625 \mu \mathrm{Ci}$ sodium [1-14C]arachidonate $(2.3 \mu \mathrm{M})$ in RPMI 1640 containing human serum albumin $(5 \mathrm{~g} / \mathrm{L})$. Then, the cells were washed twice with phosphate buffered saline, incubated with saline for $5 \mathrm{~min}$. and trypsinised. Lipids were extracted as described above and aliquots were taken to quantify incorporated radioactivity. Phospholipid classes 
were separated by TLC as described above, radioactive spots were scraped and radioactivity was counted.

For analysis of elongation products, fatty acids of total phospholipids were methylated [25] and separated by high performance liquid chromatography (HPLC) using a $\mathrm{C}_{18}$ reversed phase column (100RP, $5 \mu \mathrm{m}$, Merck), eluted with methanol/acetonitril/water (85.5:9.5:5, v/v). Radioactive peaks were analysed by a radioisotope detector (Beckmann 171, Palo Alto, California, USA)).

All fatty acid data were expressed as nmol fatty acid or dpm radiolabel per amount of cells. We have previously shown that cell number and phospholipid content are highly correlated, which is not influenced by fatty acid modification of the cells [8]. Since cellular phospholipid content can be quantified more accurately than cell mumber in small amounts of cells (by measuring phosphorus content [24]), this was measured as the determinant of cell number. All data are expressed per $8.3 \times 10^{6}$ or $8.3 \times 10^{3}$ cells, which is equivalent to $1 \mu \mathrm{mol}$ or $1 \mathrm{nmol}$ cellular phospholipid, repectively.

\section{Results}

Fatty acid composition of phospholipid classes of unmodified human endothelial cells

The distribution of the different phospholipid classes in the endothelial cell membranes is shown in Table 1 and the fatty acid compositions of these classes are summarized in fig. 1. The results show that particular fatty acids are esterified into various phospholipid classes to different extents. For example, in SM $40.6 \%$ of total fatty acids is 16:0 (fig.1a), $9.1 \%$ is $24: 0$ and $21.1 \%$ is $24: 1(n-9)$ (see appendix $A$ ). $16: 0$ is also incorporated to a high extent into CP (33.8\% of total CP fatty acids). CP actually shows the highest 16:0 mass incorporation (fig.1b). Since CP comprises $53.4 \%$ of total phospholipids, its fatty acid composition determines to a considerable extent that of the total phospholipids (fig.1b). It is also evident from fig. 1a that the relative amount of 18:0 is high in PS (35.1\%) and PI (34.0\%), although fig. 1b shows that EP contains the highest 18:0 mass. Also, PI is very rich in 20:4(n-6) (30.7\%), while EP contains the highest 20:4(n-6) mass content (fig.1b). EP, which comprises $27.0 \%$ of total phospholipids, has a relatively high content of 18:0, 18:1(n-9) and 20:4(n-6) (fig.1 a) and a relatively large mass content of $18: 0,20: 4(n-6), 22: 4(n-6), 22: 5(n-3)$ and 22:6(n-3) (fig.1b). The polyunsaturated fatty acid composition of plasmalogen EP (sn-2 position) shows no gross deviation from that of diacyl EP, except for $18: 1(n-9)$ and $18: 2(n-6)$ which are present at both the sn-1 and sn-2 positions (see appendix B). Only, 18:1(n-9) is uniformly distributed over all phospholipid classes, except for SM and plasmalogen EP. 
Table 1. Distribution of phospholipid classes in endothelial cell membranes

\begin{tabular}{cr}
\hline PL CLASSES & \% OF TOTAL \\
\hline SM & $6.7(1.5)$ \\
CP & $53.4(1.6)$ \\
PS & $6.8(0.6)$ \\
PI & $6.1(0.5)$ \\
EP & $27.0(2.8)$ \\
$\quad$ plasmalogen EP & $10.4(1.8)$ \\
diacyl EPa & $16.6(2.1)$ \\
\hline
\end{tabular}

Human umbilical vein endothelial cells were cultured to passage 4 in standard medium containing 20\% human serum. Lipids were extracted, phospholipid classes were separated and phosphorus content was analysed as described in Experimental Procedures. The distribution of phospholipid classes is expressed as percentage of total phospholipids. Values represent means (SD), $\mathrm{n}=6$. Abbreviations: PL, Phospholipid; a diacyl EP including alkyl-acyl EP ( $<0.5 \%$ of total PL)

Changes in fatty acid composition of phospholipid classes in fatty acid modified endothelial cells

In order to study the effect of fatty acid modification on the distribution of fatty acids in the different phospholipid classes, endothelial cells were cultured from passage 2 to 4 in media supplemented with $200 \mu \mathrm{M}$ of a particular fatty acid. Preliminary studies showed that higher concentrations of supplemented fatty acids inhibit cell growth. Since the medium also contains $20 \%$ human serum (containing approx. $2 \mathrm{mM}$ total fatty acids), the concentration of the supplemented fatty acids is at most doubled, assuming that this fatty acid represents $10 \%$ or more of the total fatty acids in serum. However, serum fatty acids are in part esterified which may limit their availability for incorporation into cellular lipids.

The fatty acid compositions of the phospholipid classes of unmodified cells and fatty acid modified cells are given in appendix A. As plasmalogen EP constitutes about $39 \%$ of total EP, the fatty acid modifications in the subclasses plasmalogen EP and diacyl EP (including alkyl-acyl EP) were analysed as well (appendix B). No appreciable differences in lipid phosphorus, phospholipid class distributions, and cholesterol contents between fatty acid modified cells and control cells were found. Regarding the relevance of $20: 4(n-6)$ for cellular activity, the fatty acid contents of different phospholipid classes in 20:4 modified endothelial cells are also shown in fig. 2. Comparison of fig. 1 and 2 show that supplementation of $20: 4(n-6)$ to the culture medium results in considerable changes in fatty acid composition of every phospholipid class. Not only the content of 20:4(n-6) was increased in all phospholipid classes (except for SM, see appendix A), but also its elongation product $22: 4(n-6)$. 

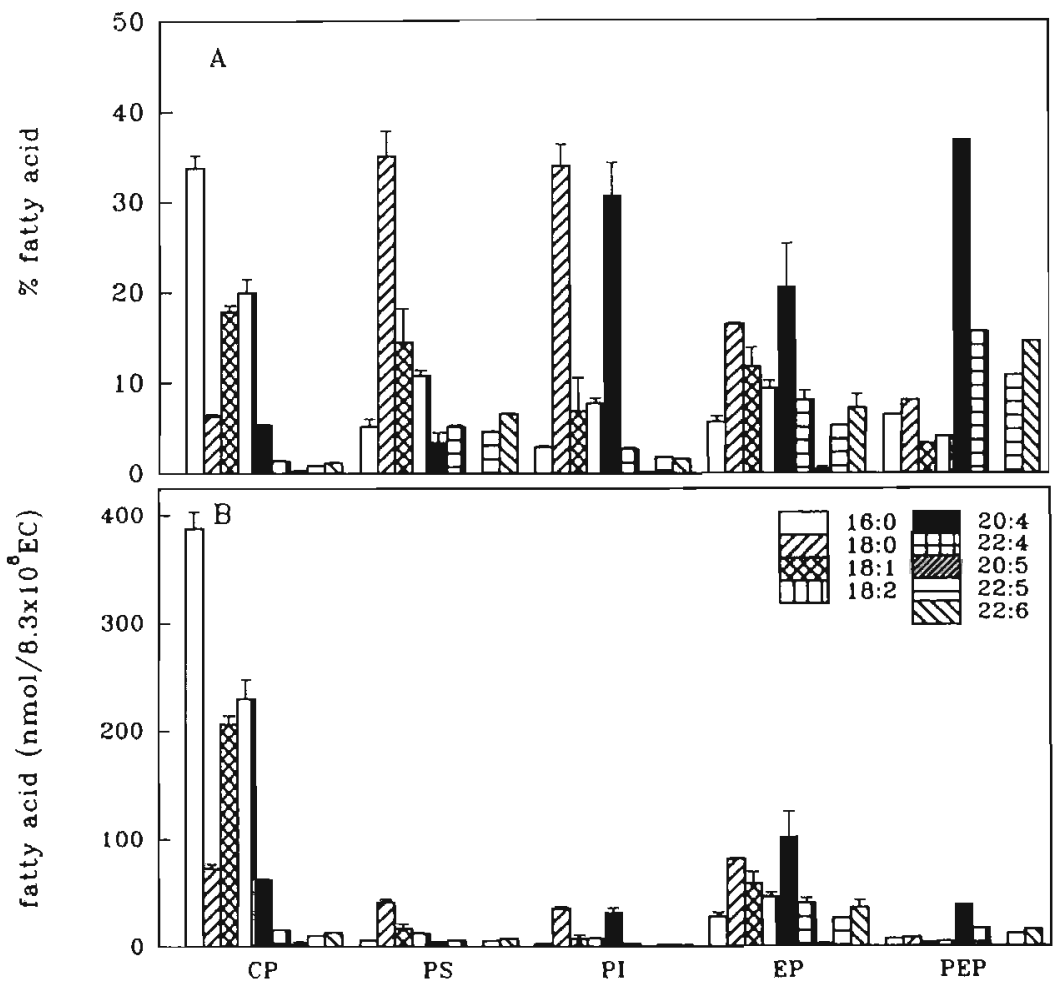

Fig. 1. Fatty acid composition of phospholipid classes in unmodified human endothelial cells. Endothelial cells were cultured to passage 4 in standard culture medium and fatty acid compositions of phospholipid classes were analysed. Only the major fatty acids are depicted here. In fig. 1 a the amounts of fatty acid in a phospholipid class are expressed as percentage of total fatty acids in that class. Fig. 1b shows the fatty acid mass content in various phospholipid classes, expressed as nmol fatty acid per $8.3 \times 10^{6}$ cells (equivalent to $1 \mu \mathrm{mol}$ cellular phospholipid). These values are calculated from the data given in table $I$ and fig. 1a. The mean values $\pm S D$ of three independent experiments are represented. Abbreviations: EC, endothelial cells; PEP, plasmalogen EP (values represent only the \% fatty acyl composition at the sn-2 position). 
20:4 modified EC

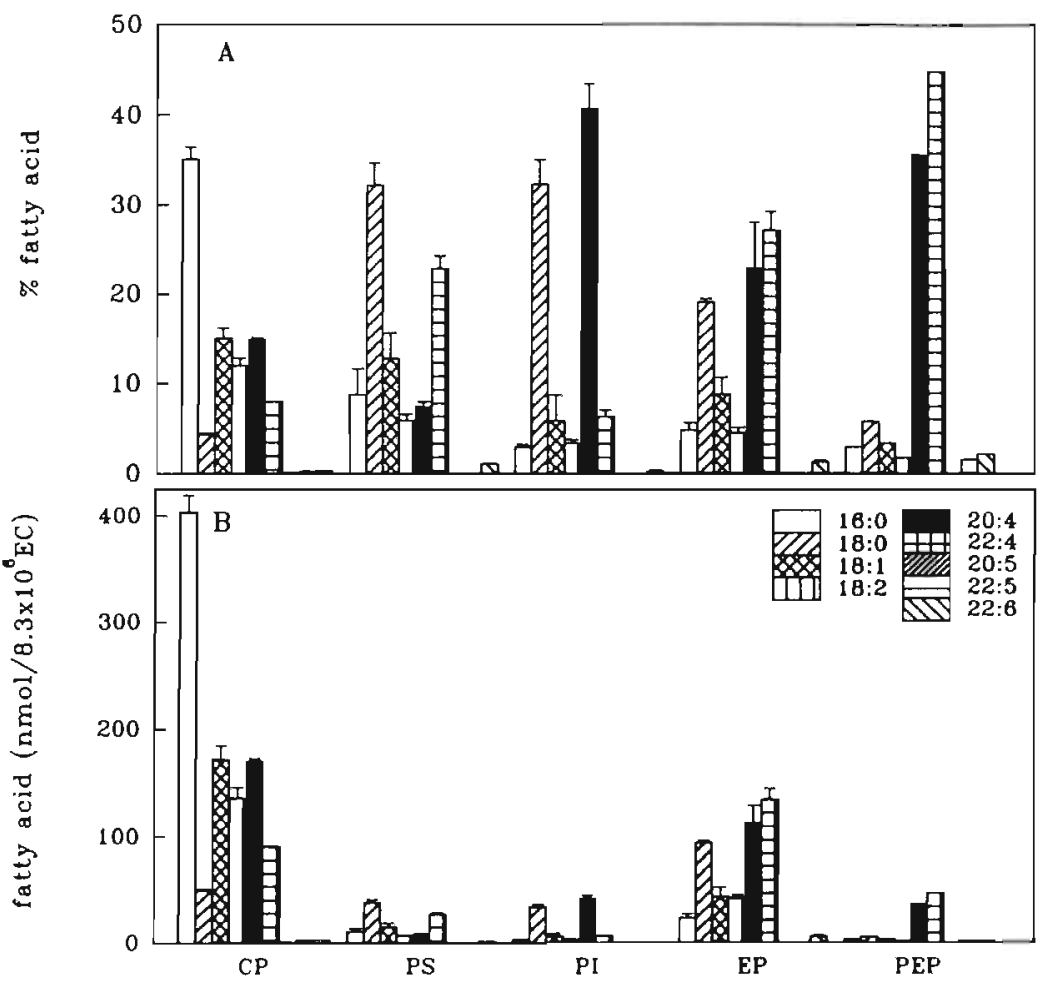

Fig. 2. Fatty acid composition of phospholipid classes in 20:4 modified endothelial cells. Endothelial cells were cultured from passage 2 to 4 in standard culture medium supplemented with 20:4(n-6) and fatty acid compositions of phospholipid classes were analysed. Only the major fatty acids are depicted here. In fig. 2a the amounts of fatty acids are expressed as a percentage of total fatty acids per phospholipid class. Fig. 2b shows the fatty acid mass contents, expressed as nmol fatty acid per $8.3 \times 106$ cells (equivalent to $1 \mu \mathrm{mol}$ cellular phospholipid). These values are calculated from data given in table I and fig. 2a. The mean \pm SD of three independent experiments are represented. Abbreviations as in fig. 1. 
Especially PS and EP were enriched with 22:4(n-6) (fig.2a)). In plasmalogen EP, 22:4(n-6) content was somewhat higher than that of $20: 4(n-6)$, while absolute mass of $20: 4(n-6)$ was highest in CP.

Some examples of preferential incorporation of supplemented fatty acids in phospholipid classes of modified cells are given below (see appendix A and B): 22 carbon polyunsaturated fatty acids (especially elongation products in 20:4 and 20:5 modified endothelial cells) were preferentially incorporated into PS and EP. Plasmalogen EP was enriched in $22: 4(n-6), 22: 5(n-3)$ and $22: 6(n-3)$ in all cells modified with polyunsaturated fatty acids. In plasmalogen EP of saturated fatty acid modified cells, an increased content of $20: 4(\mathrm{n}-6)$ was found compared to that of diacyl EP. The fatty acids $20: 4(\mathrm{n}-6)$ and 18:0 were highly incorporated into PI of 18:0 modified cells, and 20:4(n-6) and 16:0 were enriched in PI of 16:0 modified cells. SM was enriched in the elongation products 24:1(n-9) and 24:2(n-6) in 18:1 and 18:2 modified cells, respectively.

Comparison of fig. 1 and 2 also show that an increase of $20: 4(n-6)$ and $22: 4(n-6)$ is accompanied by a decrease of the fatty acids $18: 2(n-6)$, 22:5(n-3) and 22:6(n-3). This compensation mechanism was seen also in every phospholipid class. Only SM, which has an extremely low 20:4(n-6) content, was somewhat diverging and showed a remarkable increase of 16:0 (from $40.6 \%$ to $46.2 \%$ ) with smaller decreases of $18: 0$ and $18: 1(n-9)$ in 20:4 modified cells (fig.2a). It is evident from the data shown in the appendix that for cells modified with polyunsaturated fatty acids, in each phospholipid class increases in these fatty acids were balanced by decreases in other polyunsaturated fatty acids. For cells modified with saturated fatty acids, increases in saturated fatty acids were balanced by increases in 20:4(n-6) content in every phospholipid class and plasmalogen EP (except SM, see appendix A).

In general, the net effect of all fatty acid changes was a fairly constant distribution pattern of saturated, monounsaturated and polyunsaturated fatty acids in each phospholipid class, as is shown in fig. 3. PI and EP have a relatively high polyunsaturated fatty acid content, whereas SM has an fairly high saturated fatty acid content with somewhat diverging fatty acid group distributions. CP and PS have an intermediate fatty acid group distribution. While there are only small differences in fatty acid group distributions of cells modified with saturated and polyunsaturated fatty acids, 18:1 modified cells show a remarkable increase in monounsaturated fatty acids at the expense of both saturated and polyunsaturated fatty acids in every phospholipid class.

Incorporation of $[1-14 \mathrm{C}]$ arachidonic acid into total phospholipids and neutral lipids of fatty acid modified endothelial cells

Since not all phospholipid classes contribute to the same extent to the liberation of $20: 4(n-6)$ for production of eicosanoids, it is of interest to 


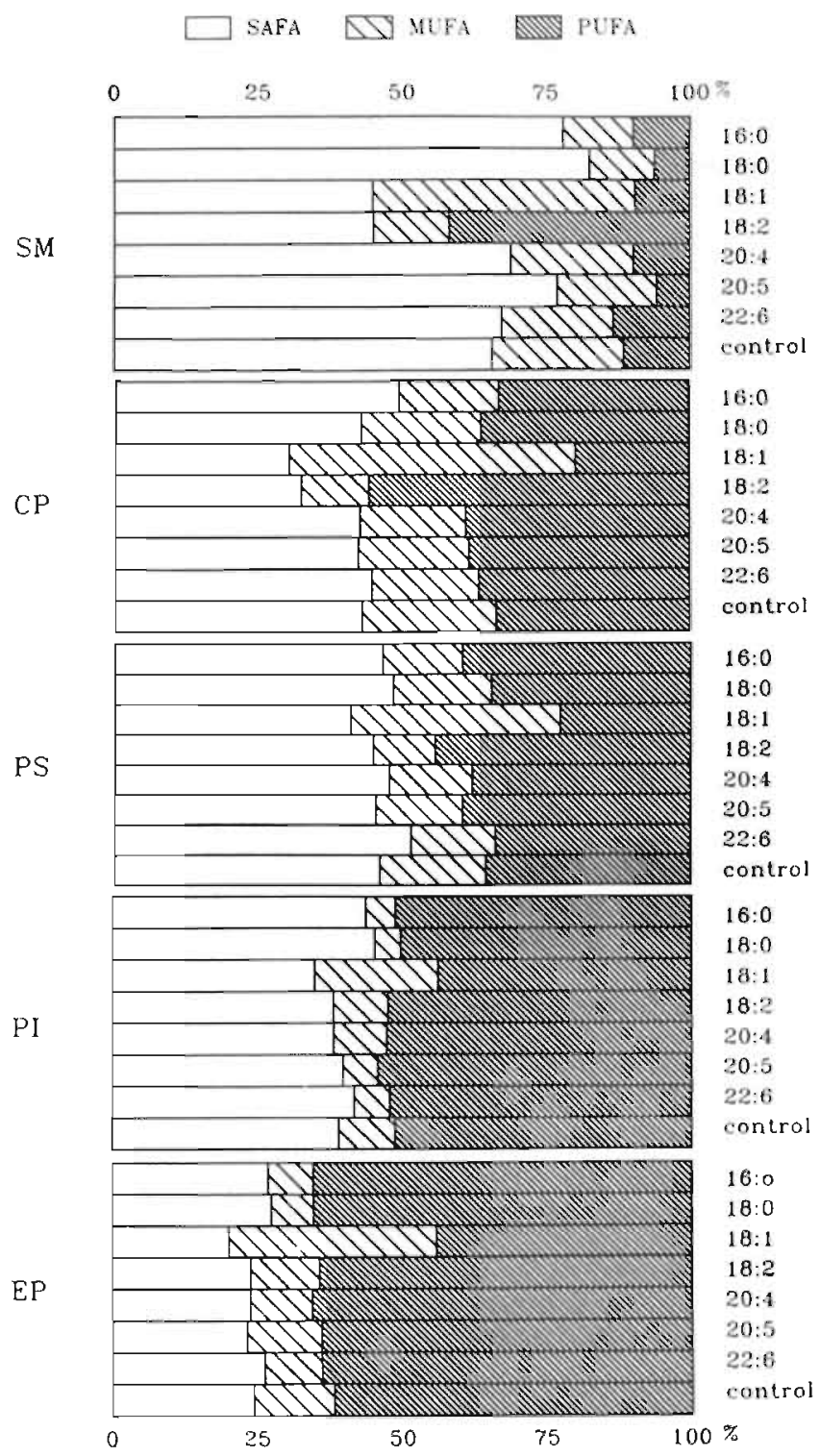

Fig. 3. Distribution patterns of fatty acid groups in phospholipid classes of differently modified endothelial cells. Endothelial cells were cultured from passage 2 to 4 in standard culture medium supplemented with different fatty acids and fatty acid compositions of phospholipid classes were analysed. The fatty acids were divided among three fatty acid groups: saturated (SAFA), monounsaturated (MUFA) and polyunsaturated (PUFA) fatty acids, expressed as percentage of total fatty acids in a phospholipid class. Values represent the mean of three independent experiments. Abbreviations: control indicates control cells cultured withour supplemented fatty acid; 16:0, 18:0, 18:1, 18:2, 20:4, 20:5, and 22:6 indicate endothelial cells cultured with palmitic, stearic, oleic, linoleic, arachidonic, eicosapentaenoic and docosahexaenoic acid, respectively. 
know whether the incorporation, distribution and modification of exogenously added 20:4(n-6) in different phospholipid classes was influenced by membrane fatty acid modification. Therefore, fatty acid modified endothelial cells at passage 4 were either incubated for 2 hours with [1${ }^{14} \mathrm{C}$ ]arachidonic acid in RPMI1640 containing human serum albumin (5 $\mathrm{g} / \mathrm{L}$ ) or were cultured for 3 days with $[1-14 \mathrm{C}]$ arachidonic acid in fatty acid supplemented media. The incorporation of radiolabel into phospholipids and neutral lipids is shown in fig. 4 . No differences in total $[1-14 \mathrm{C}]$ arachidonic acid incorporation were found between differently modified endothelial cells at 2 hours incubation or 3 days culture. However, after 3 days culture the incorporation of radiolabel into phospholipids was increased with increasing amount of unlabeled 20:4(n-6) already present in the phospholipids of the differently modified cells, as could be expected. The incorporation into neutral lipids (predominantly triglycerides) was much lower than in phospholipids, except for 20:4 modified endothelial cells, which showed a relatively high increase of radiolabel into neutral lipids.

It should be noted that during 3 days culture of endothelial cells in 20:4 modified media, dilution of radiolabel occurs already in the culture medium. Therefore, the actual mass incorporation of 20:4(n-6) is much higher than would be concluded from the dpm values of 20:4 modified cells shown in fig. 4B. This, however, does not influence the ratio of radiolabel incorporation into phospholipids to that into neutral lipids.

\section{Elongation of $[1-14 \mathrm{C}]$ arachidonic acid in differently modified endothelial cells}

By means of HPLC analyses, modification of incorporated [1${ }^{14} \mathrm{C}$ ]arachidonic acid was determined for the differently modified endothelial cells (table 2). After 2 hours incubation, a large amount of $20: 4(n-6)$ was already elongated to $22: 4(n-6)$. No desaturation products or further elongation of $22: 4(n-6)$ were found. The percentage elongation in total phospholipids after 2 hours incubation was between $17 \%$ and $22 \%$ for all fatty acid modified cells, except for 20:5 modified cells (7\%). After 3 days culture the percentage elongation was further increased in all cells, but still rather low in 20:5 modified endothelial cells (table 2). 20:4 and 18:1 modified cells showed the highest percentage elongation after 3 days culture. Table 3 shows the incorporation of the elongated product into various phospholipid classes of 20:4 modified endothelial cells. These data are consistent with the previous observations that $22: 4(n-6)$ is incorporated preferentially into PS and EP.

It cannot be excluded that part of the $[1-14 \mathrm{C}]$ arachidonate may release ${ }^{14} \mathrm{C}$ through beta-oxidation, followed by reincorporation of the label into de novo synthesized fatty acids including $22: 4(n-6)$ in a 3 day culture period. However, we examined radiolabel incorporation into all major 


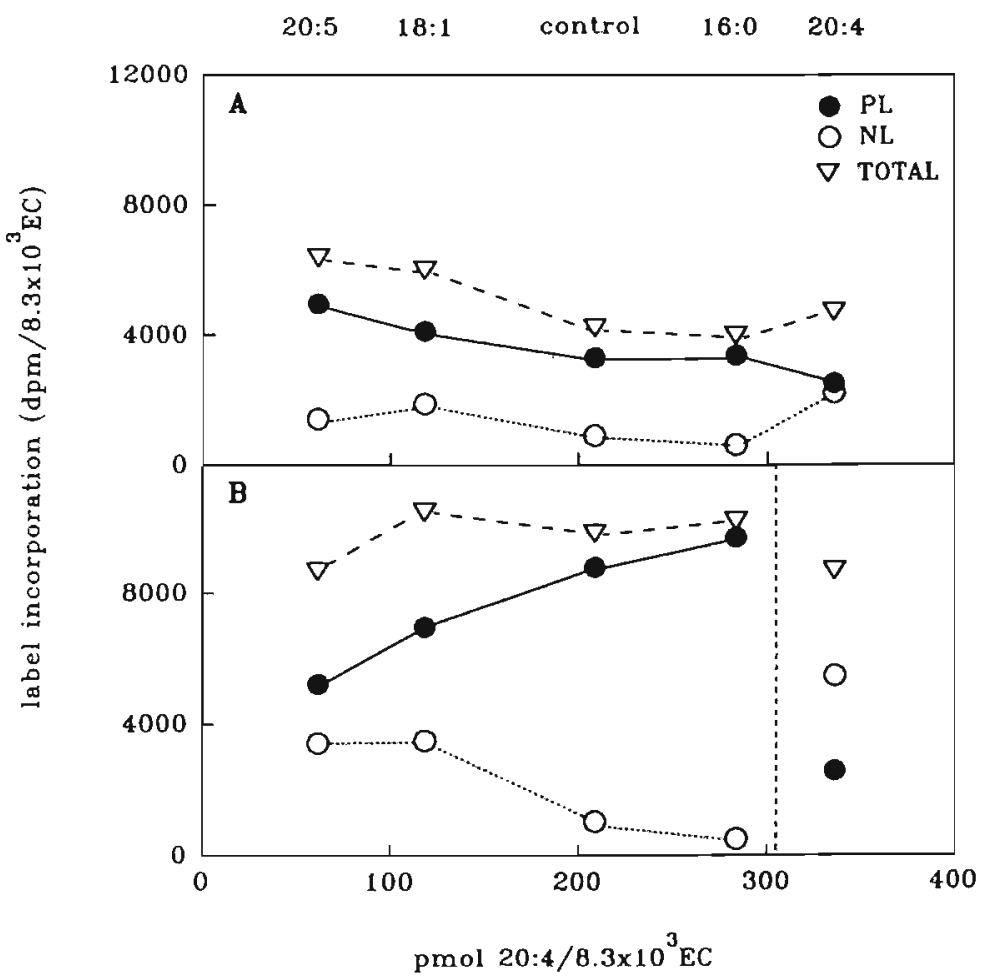

Fig. 4. Incorporation of radiolabel in phospholipids and neutral lipids of differently modified endothelial cells. At passage 4 endothelial cells, modified with different fatty acids, were either incubated for 2 hours or cultured for 3 days with [1-14C]arachidonic acid. Lipids were analysed by TLC. At the y-axis incorporation of radiolabel is depicted for the 2 hours incubation (fig.4A) or the 3 days culture (fig.4B), expressed as dpm per $8.3 \times 10^{3}$ cells. At the $x$-axis the content of unlabeled $20: 4(n-6)$ in the total phospholipids of fatty acid modified endothelial cells (after 7 or 8 days culture) is depicted (8). On top of the fig. it is indicated which fatty acid endothelial cells are modified with. Values are from one experiment, representative of two independently performed. Abbreviations as in fig. 3. For 20:4 modified endothelial cells after 3 days culture, the dpm values represent a much larger 20:4(n-6) mass incorporation because of dilution of radiolabel in the 20:4 modified culture medium.

fatty acids by HPLC and detected radiolabel incorporation almost exclusively into $20: 4(\mathrm{n}-6)$ and $22: 4(\mathrm{n}-6)$, which always accounted for more than $97 \%$ of total radiolabel measured (including minor unidentified peaks). Most probably, other fatty acids would be labelled as well, when ${ }^{14} \mathrm{C}$ would have been released from arachidonate and reused in measurable amounts in de novo lipid synthesis. 
Table 2. Percentage of elongated $\left[1-{ }^{14} \mathrm{C}\right]$ arachidonic acid in differently modified endothelial cells

\begin{tabular}{|c|c|c|}
\hline \multirow{2}{*}{$\begin{array}{l}\text { EC modified } \\
\text { with }\end{array}$} & \multicolumn{2}{|c|}{$\% 22: 4(n-6)$} \\
\hline & 2 HOURS & 3 DAYS \\
\hline control & 17.3 & 35.6 \\
\hline $16: 0$ & 20.7 & 34.1 \\
\hline $18: 1$ & 21.6 & 43.6 \\
\hline $20: 4$ & 17.5 & 41.1 \\
\hline $20: 5$ & 7.0 & 12.7 \\
\hline
\end{tabular}

Endothelial cells were cultured from passage 2 to 4 in various fatty acid modified media. Then, cells were either incubated for 2 hours or cultured for 3 days with $[1-14 \mathrm{C}$ ]arachidonic acid. Lipids were extracted and analysed by TLC and HPLC as described in Experimental Procedures. Percent elongation is calculated as dpm $22: 4 / \mathrm{dpm}(20: 4+22: 4) \times 100$. Values are from one experiment representative of two independently performed. Abbreviations: EC, endothelial cells

Table 3. Percentage of elongated $\left[1-{ }^{14} \mathrm{C}\right]$ arachidonic acid in phospholipid classes of 20:4 modified endothelial cells

\begin{tabular}{cc}
\hline PL in & $\begin{array}{c}\text { \%2:4(n-6) } \\
\text { 30:4 EC }\end{array}$ \\
\hline PS & 66.7 \\
EP & 50.7 \\
CP & 36.7 \\
PI & 30.3 \\
SM & ND \\
NL & 40.7 \\
\hline
\end{tabular}

Procedure and calculations as described in table 2. Values are from one experiment, representative for two independently performed. Abbreviations: NL, neutral lipids; ND, not detected; 20:4 EC, endothelial cells modified with arachidonic acid

Distribution of [1-14C]arachidonic acid among phospholipid classes of differently modified endothelial cells

The radiolabel distributions among phospholipid classes of differently modified endothelial cells after 2 hours incubation and 3 days culture are shown in fig. 5a and $5 b$, respectively. The distribution patterns of radiolabel among the various phospholipid classes were similar for differently 


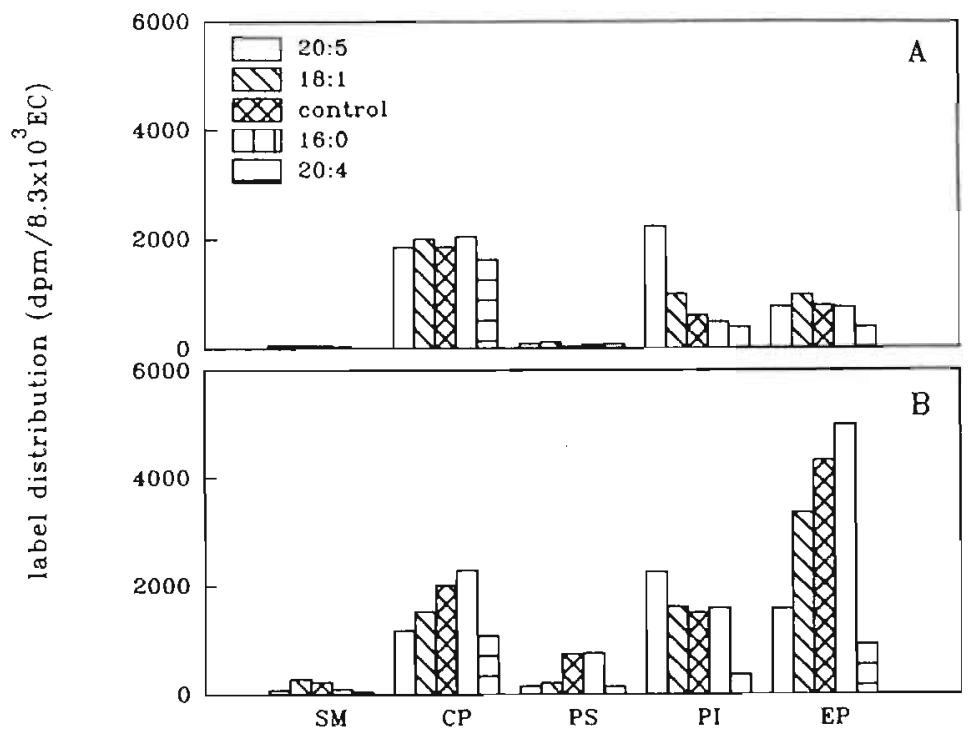

Fig. 5. Distribution of radiolabel among phospholipid classes in differently modified endothelial cells. Procedure as described in fig 4. Radiolabel distribution among phospholipid classes of differently modified endothelial cells are shown after 2 hours incubation in fig. 5A and after 3 days culture in fig. 5B, expressed as dpm per $8.3 \times 10^{3}$ cells. Values are from one experiment, representative of two independently performed. Abbreviations as in fig. 3. For 20:4 modified endothelial cells after 3 days culture, the dpm values represent a much larger 20:4(n-6) mass incorporation because of dilution of radiolabel in the 20:4 modified culture medium.

modified endothelial cells. However, 20:5 modified endothelial cells formed an exception. These cells showed a relatively high incorporation of radiolabel into PI compared to other cells. Also, the incorporation in total phospholipids after 2 hours incubation was higher in these cells than that in other modified cells.

After 3 days culture, incorporation of radiolabel into all classes was increased, especially into EP. In fact the overall pattern shows a shift in radiolabel incorporation from CP to EP when the 2 hours and 3 days data were compared. The distribution patterns after 3 days culture resembled those of unlabeled fatty acids. For 20:5 modified endothelial cells, again a relatively high incorporation of radiolabel into PI was found, which was not increased, however, compared to that of 2 hours.

The efficiency of radiolabel incorporation for each phospholipid class per sé is depicted in fig. $6 \mathrm{~A}$ and $6 \mathrm{~B}$ for 2 hours incubation and 3 days culture, respectively. The results after 2 hours incubation showed a high labeling efficiency of PI for all modified endothelial cells, whereas 20:5 modified cells showed a relatively higher labeling efficiency of PI, which was still found after 3 days culture. 


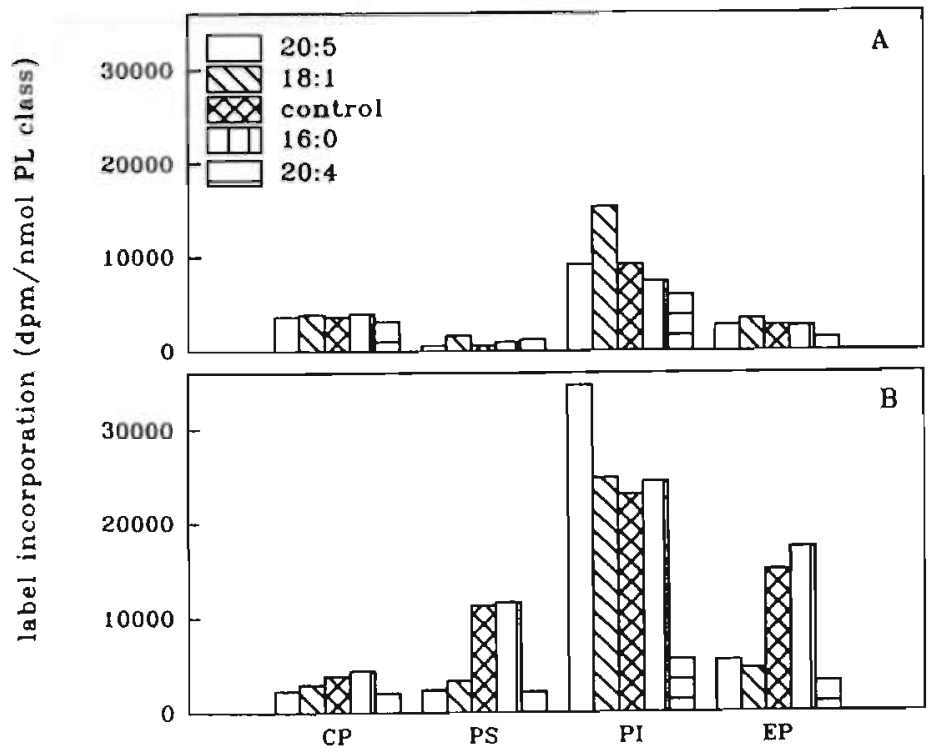

Fig. 6. Efficiency of radiolabel incorporation per phospholipid class in differently modified endothelial cells. Procedure as described in fig. 4. In order to show the efficiency of label incorporation for the different phospholipid classes per se, radiolabel incorporation for each phospholipid class was calculated as dpm incorporated radiolabel in a phospholipid class divided by pmol amount of that phospholipid class. Values are from one experiment, representative of two independently performed. Abbreviations as in fig. 3.

\section{Discussion}

Several studies $[3,4,8]$ have shown that, culturing of endothelial cells in media supplemented with a particular fatty acid results in increased levels of this fatty acid and its elongated product in total membrane phospholipids. We have reported previously that such an increase of a particular fatty acid is always balanced by a change in the level of other fatty acids, and this apparent 'homeostatic' control is also found at the level of cellular functional activity upon long-term fatty acid modification [8]. The present data are consistent with these observations and show, in addition, that such a phenomenon is not only present in the total phospholipids, but id also apparent within each individual phospholipid class. The present results show that, in general, long-term fatty acid modifications do not appreciably influence the mean levels of saturated and unsaturated fatty acids per phospholipid class. A notable exception was found in 18:1 modified cells, which show an increase in monounsaturated fatty acids at the expense of both saturated and unsaturated fatty acids. This indicates subtle control of membrane unsaturation in each phospholipid class. 
As essential fatty acids exert special functions, it could be hypothesized that $20: 4(n-6)$ has a dual role in the membrane. It is not only involved in the regulation of membrane physico-chemical parameters, but it also serves as a substrate pool for local eicosanoid mediators. Since fatty acid modification of endothelial cells considerably changes the $20: 4(n-6)$ content of individual phospholipid classes, the availability of $20: 4(n-6)$ for the formation of bioactive mediators upon cell stimulation may also be changed. Therefore, the incorporation, distribution and modification of [1-14C]arachidonic acid into phospholipids and neutral lipids of differently modified endothelial cells were studied after 2 hours incubation and after 3 days culture.

After a 2 hours incubation, $[1-14 \mathrm{C}]$ arachidonic acid is incorporated to about the same extent into the phospholipid fraction of differently modified endothelial cells. This indicates that the initial radiolabel incorporation is not influenced by fatty acyl modification. After 3 days culture, radiolabel incorporation into total phospholipids reflects its actual 20:4 (n-6) mass content. $[1-14 \mathrm{C}]$ arachidonic acid is incorporated to a large extent, however, into the neutral lipid fraction (mostly triglycerides) of 20:4 modified endothelial cells after 3 days, while incorporation into triglycerides is relatively low in other cells. It is possible that in 20:4 modified cells the membrane phospholipids as well as the culture medium are already "saturated" with 20:4(n-6), so that newly incorporated 20:4 (n-6) will be "stored" into triglycerides. Consistently, in 16:0 modified cells only a limited amount of 20:4(n-6) is available from the culture medium (in 20\% human serum) and is therefore incorporated directly into phospholipids for compensatory reasons. Indications for "storage" regulation of excess $20: 4(n-6)$ into triglycerides of cultured cells has been reported also by others $[11,19]$. In addition, Cunnane reported retention of 20:4(n-6) in triglycerides of plasma and liver of fasting rats [27].

Another mechanism for "storage" of sufficient $20: 4(n-6)$ into endothelial cells might be the elongation of $20: 4(n-6)$ to $22: 4(n-6)$ which is subsequently "stored" into PS and EP (including plasmalogen EP), phospholipid classes with a relatively low tumover rate [2]. If necessary, 20:4(n-6) can be replenished by retroconversion of the "stored" 22:4(n6). Rosenthal et al. [21] recently have reported that efficient retroconversion can occur in both fibroblasts and endothelial cells. Elongation products of other fatty acids are also selectively incorporated into specific phospholipid classes, for example 24:1(n-9) and 24:2(n-6) into SM of 18:1 and 18:2 modified cells, respectively. In the present study as well as in that of Rosenthal et al. [21], prolonged elongation of 20:4(n-6) is found in endothelial cells after 3 days modification with 20:4(n-6). For 20:5 modified cells, less elongation of $20: 4(n-6)$ but more elongation of 20:5(n-3) to $22: 5(n-3)$ is found, which is incorporated preferentially into PS and EP (including plasmalogen EP). This points to the importance of 
long time culture for achieving equilibrium conditions when studying the fate of exogenously added fatty acids.

Analysis of the fatty acid modifications in plasmalogen EP show a slightly increased content of 22 carbon elongation products in cells modified with different polyunsaturated fatty acids, and an increased content of $20: 4(n-6)$ in saturated fatty acid modified cells compared to that of diacyl EP (including alkyl-acyl EP). However, no gross deviations from the general pattem are found, taking into account that the fatty acid composition of plasmalogen EP is derived only from the sn-2 position, in contrast to that of diacyl EP.

For all modified endothelial cells, a rapid incorporation of [1${ }^{14} \mathrm{C}$ ]arachidonic acid is found into $\mathrm{CP}$ and $\mathrm{PI}$ after 2 hours, followed by a redistribution from $\mathrm{CP}$ to $\mathrm{EP}$ in 3 days without stimulation of the cells. This time dependent transesterification of 20:4(n-6), also reported by others $[5,16,19,20]$, appears not to be influenced by fatty acid modification and membrane 20:4(n-6) content. Takayama [16] showed that this remodeling is highly selective for $20: 4(n-6)$ and $20: 5(n-3)$.

Typically, a relatively high efficiency of radiolabel incorporation is found in PI of 20:5 modified endothelial cells. With regard to the high turnover rate of PI $[14,28,29]$, this indicates a very efficient and specific incorporation mechanism for 20:4(n-6) into PI. This effect is most evident in 20:5 modified cells, which are relatively poor in 20:4(n-6) because of competition by $20: 5(n-3)$. The fast incorporation, relatively high level, and low extent of elongation of 20:4(n-6) in PI of 20:5 modified cells could be interpreted as control of a critical 20:4(n-6) level in the PI class of endothelial membranes, possibly important for effective signal transduction upon cellular stimulation.

Finally, the results of the present study can be put into a physiological context. One functional role of fatty acids, as part of phospholipids in biomembranes, is providing a suitable physico-chemical environment for "membrane-associated processes". This may allow extensive variations in fatty acid content of all phospholipid classes, within 'homeostatic' control of physico-chemical properties, as determined by all phospholipid classes together. A second function of the essential fatty acid $20: 4(n-6)$ is to provide as a precursor pool for local mediator formation during cell stimulation. For this cellular response, however, not all phospholipid classes participate to the same extent $[2,9]$. For the rapid initial response, the PI-class (including 20:4(n-6) release mediated by PI-specific phospholipase $\mathrm{C}$ and diacyl glycerol lipase) is important, while for the further amplification of the activation response, liberation of arachidonic acid by phospholipase $\mathrm{A}_{2}$ from other classes ( $\mathrm{CP}$ and $\mathrm{EP}$ ) also plays a role. The present results indicate that the cells carefully maintain a critical 20:4 (n-6) level in PI irrespective of adaptation to different fatty acid containing media. This presumably explains why the functional cellular reactivity remains virtually unaltered in the endothelial cells modified 
with different fatty acids [8]. However, the observation that the 20:4(n-6) content of other phospholipid classes can vary considerably may imply that alterations in membrane fatty acid content, which influence eicosanoid formation [8], have consequences for the amplification of the cellular response, for example in inflammatory reactions and hemostatic processes.

\section{Acknowledgement}

The authors wish to thank Marianne Simonis for technical assistance with gas-liquid chromatography, Mariet Molenaar for typing the manuscript, the Department of Obstetrics and Gynaecology (De Wever Hospital, Heerlen) for supply of umbilical cords and the Red Cross Bloodbank Limburg (Maastricht) for supply of human serum.

\section{References}

1 Gimbrone, M.A. 1986. Vascular endothelium; nature's blood container. in: Vascular Endothelium in Hemostasis and Thrombosis. (M. A. Gimbrone, ed.) Churchill Livingstone, New York. pp 1-13

2 Stubbs, C.D., and Smith, A.D. 1984. The modification of mammalian membrane polyunsaturated fatty acid composition in relation to membrane fluidity and function. Biochim. Biophys. Acta. 779, 89-137

3 Spector, A.A., and Yorek, M.A. 1985. Membrane lipid composition and cellular function. J. Lipid Res. 26, 1015-1035

4 Spector, A.A., Kaduce, T.L., Hoak, F.C., and Fry, G.L. 1981. Utilization of arachidonic and linoleic acids by cultured human endothelial cells. J. Clin. Invest. 68, 1003-1011

5 Wey, H.E., Jakubowski, J.A., and Deykin, D. 1986. Incorporation and redistribution of arachidonic acid in diacyl and ether phospholipids of bovine aortic endothelial cells. Biochim. Biophys. Acta. 878, 380-386

6 Dicorletto, P.E., and Chisolm, G.M. 1986. Participation of the endothelium in the development of the atherosclerotic plaque. Prog. Lipid Res. 25, 365-374

7 Irvine, R.F. 1982. How is the level of free arachidonic acid controlled in mammalian cells Biochem. J. 204, 3-16

8 Vossen, R.C.R.M., Dam-Mieras, M.C.E. van, Lemmens, P.J.M.R., Hornstra, G., and Zwaal, R.F.A. 1991. Membrane fatty acid composition and endothelial cell functional properties. Biochim. Biophys. Acta. 1083, 243-251

9 Nozawa, Y., Nakashima, S., and Nagata, K. 1991. Phospholipid-medialed signaling in receptor activation of human platelets. Biochim. Biophys. Acta. 1082, 219-238

10 Hong, S.L., and Deykin, D. 1982. Activation of phospholipases $A_{2}$ and $C$ in pig aortic endothelial cells synthesizing prostacyclin. J. Biol. Chem. 257, 7151-7154

11 Denning, G.M., Figard, P.H., Kaduce, T.L., and Spector, A.A. 1983. Role of triglycerides in endothelial cell arachidonic acid metabolism. J. Lipid. Res. 24, 993-1001

12 Hong, S.L., McLaughlin, N.J., Tzeng, C., and Patton, G. 1985. Prostacyclin synthesis and deacylation of phospholipids in human endothelial cells: companson of thrombin, histamin and ionophore $A_{23187}$. Thrombosis Res. 38, 1-10

13 Brown, M.L., Jakubowski, J.A., Leventis, L.L., and Deykin, D. 1987. Ionophore-induced metabolism of phospholipids and eicosanoid production in porcine aortic endothelial cells: selective release of arachidonic acid trom diacyl and ether phospholipids. Biochim. Biophys. Acta. 921, 159-166

14 Takayama, H., Jr. Gimbrone, M.A., and Schafer, A.I. 1987. Preferential incorporation of eicosanoid precursor fatty acids into human umbilical vein endothelial cell phospholipids. Biochim. Biophys. Acta. 922, 314-322 
15 Ragab-Thomas, J.M.F., Hullin, F., Chap, H., and Douste-Blazy, L. 1987. Pathways of arachidonic acid liberation in thrombin and cakium ionophore $A_{23187}$-stimulated endothelial cells: respective roles of phospholipids and triacylglycerol and evidence for diacylglycerol generation from phosphatidylcholine. Biochim. Biophys. Acta. 917, 388-397

16 Takayama, H., Kroll, M.H., Gimbrone, M.A., and Schafer, A. I. 1989. Tumover of eicosanoid precursor fatty acids among phospholipid classes and subclasses of cultured human umbilical vein endothelial cells. Biochem. J. 258, 427-434

17 Martin, T.W., and Michaelis, K.C. 1990. Ca2t-dependent synthesis of prostaglandin I2 and mobilization of arachidonic acid from phospholipids in cultured endothelial cells permeabilized with saponin. Biochim. Biophys. Acta. 1054, 154-168

18 Thomas, J.M.F., Hullin, F., Chap, H., and Douste-Blazy, L. 1984. Phosphatidylcholine is the major phospholipid providing arachidonic acid for proslacylcin synthesis in thrombinstimulated human endothelial cells. Thrombosis Res. 34, 117-123

19 Sivarajan, M., Hall, E.R., Wu, K.K., Rafelson, M.E., and Manner, C.E. 1984. Regulation of intracellular arachidonate in normal and stressed endothelial cells. Biochim. Biophys. Acta. 795, 271-276

20 Hall, E.R., Manner, C.E., Carinkas J., Snopko, R., and Rafelson, M 1987. Selective intemalization of arachidonic acid by endothelial cells. Biochem. J. 245, 151-157

21 Rosenthal, M.D., Garcia, M.C., Jones, M.R., and Sprecher, H. 1991. Retroconversion and $\Delta^{4}$ desaluration of docosatetraenoale $(22: 4(n-6))$ and docosapentaenoate $(22 \cdot 5(n-3))$ by human cells in culture. Biochim. Biophys. Acta. 1083, 29-36

22 Maciag, T., Cerundole, I., Istey, S., Kelly, P.R., and Foriand, R. 1979. An endothelial cell growth factor from bovine hypothalamus: identification and partial characterization. Proc. Nat. Acad. Sci. USA.76, 5674-5678

23 Bligh, E.R., and Dyer, W.J. 1959. A rapid method for total lipid extraction and purification. Can. J. Biochem. Physiol. 37, 911-918

24 Bottcher, C.J.F., Gent, C.M. van, and Pries, C. 1961. A rapid and sensitive sub-micro phosphorus determination. Anal. Chim. Acta. 24, 203-204

25 Rand, M.L., Hennissen, A.A.H.M., and Hornstra, G. 1986. Effects of dietary sunflowerseed oil and marine oil on platelet membrane fluidity, arterial thrombosis, and platelet responses in rats. Atherosclerosis. $62,267-276$

26 Touchsione, J.C., Chen, J.C., and Beaver, K.M. 1980. Improved separation of phospholipids in thin layer chromatography. Lipids .15, 61-62

27 Cunnane, S.C. 1990 Differential utilization of long chain fatty acids during fasting-induced triacylglycerol depletion. III. Comparison of n-3 and n-6 fatty acids in rat plasma and liver. Biochim. Biophys. Acta. 1036, 64-70

28 Holub, B.J. 1987. The cellular forms and functions of the inositol phospholipids and their metabollc derivatives. Nutrition Rev. 45, 65-71

29 Blank, M.L., Spector, A.A., Kaduce, T.L., and Snyder, F. 1986. Composition and incorporation of $\left[{ }^{3} \mathrm{H}\right]$ arachidonic acid into molecular species of phospholipid classes by cultured human endothelial cells. Biochim. Biophys. Acta. 87, 211-215 


\begin{tabular}{|c|c|c|c|c|c|c|c|c|c|}
\hline \multirow[b]{2}{*}{ PL class } & \multirow[b]{2}{*}{ Farty acid } & \multicolumn{6}{|c|}{ Fatty acid supplemented to culture medium } & \multirow[b]{2}{*}{$20: 5$} & \multirow[b]{2}{*}{ 22:6 } \\
\hline & & None & $16: 0$ & $18: 0$ & $18: 1$ & $18: 2$ & $20: 4$ & & \\
\hline SM & $\begin{array}{l}16: 0 \\
18: 0 \\
18: 1(n-9) \\
18: 2(n-6) \\
20: 4(n-6) \\
22: 6(n-3) \\
22: 0 \\
24: 0 \\
24: 1(n-9) \\
24: 2(n-6)\end{array}$ & $\begin{array}{r}40.6 \\
4.8 \\
0.3 \\
1.1 \\
0.7 \\
0.0 \\
4.1 \\
9.1 \\
21.1 \\
9.3\end{array}$ & $\begin{array}{r}47.0 \\
7.5 \\
0.1 \\
1.6 \\
1.0 \\
0.0 \\
6.0 \\
10.3 \\
9.7 \\
4.2\end{array}$ & $\begin{array}{r}36.9 \\
16.4 \\
0.7 \\
1.4 \\
2.6 \\
0.0 \\
12.0 \\
9.5 \\
8.6 \\
2.9\end{array}$ & $\begin{array}{r}31.6 \\
3.6 \\
1.2 \\
0.6 \\
1.1 \\
0.2 \\
3.2 \\
4.2 \\
40.5 \\
5.7\end{array}$ & $\begin{array}{r}36.1 \\
2.7 \\
0.7 \\
3.1 \\
0.7 \\
0.1 \\
2.9 \\
4.0 \\
10.1 \\
33.2\end{array}$ & $\begin{array}{r}46.2 \\
4.6 \\
2.0 \\
1.1 \\
1.4 \\
0.3 \\
4.7 \\
7.2 \\
15.4 \\
3.7\end{array}$ & $\begin{array}{r}50.2 \\
5.9 \\
0.6 \\
1.1 \\
1.6 \\
0.0 \\
5.7 \\
8.7 \\
15.3 \\
3.5\end{array}$ & $\begin{array}{r}4.5 .5 \\
5.3 \\
0.3 \\
2.0 \\
1.3 \\
0.7 \\
4.3 \\
8.9 \\
17.1 \\
8.7\end{array}$ \\
\hline 更 & $\begin{array}{l}16: 0 \\
18: 0 \\
18: 1(n-9) \\
18: 2(n-6) \\
20: 2(n-6) \\
20: 3(n-6) \\
20: 4(n-6) \\
20: 5(n-3) \\
22: 4(n-6) \\
22: 5(n-3) \\
22: 6(n-3)\end{array}$ & $\begin{array}{r}33.8 \\
6.3 \\
17.9 \\
20.0 \\
1.4 \\
1.6 \\
5.4 \\
0.2 \\
1.4 \\
0.9 \\
1.2\end{array}$ & $\begin{array}{r}41.1 \\
6.0 \\
13.4 \\
14.8 \\
0.8 \\
2.3 \\
9.5 \\
0.5 \\
1.2 \\
1.2 \\
1.6\end{array}$ & $\begin{array}{r}23.7 \\
17.1 \\
17.4 \\
17.1 \\
0.7 \\
2.3 \\
10.1 \\
0.5 \\
1.1 \\
1.0 \\
1.7\end{array}$ & $\begin{array}{r}24.1 \\
3.9 \\
44.9 \\
10.8 \\
0.7 \\
1.0 \\
3.0 \\
0.1 \\
1.2 \\
0.7 \\
0.9\end{array}$ & $\begin{array}{r}26.4 \\
4.0 \\
8.9 \\
43.1 \\
5.3 \\
1.5 \\
2.5 \\
0.3 \\
1.2 \\
0.3 \\
0.6\end{array}$ & $\begin{array}{r}35.1 \\
4.3 \\
15.0 \\
11.9 \\
0.6 \\
1.7 \\
14.9 \\
0.1 \\
7.9 \\
0.2 \\
0.3\end{array}$ & $\begin{array}{r}34.7 \\
5.6 \\
16.1 \\
14.9 \\
0.5 \\
0.7 \\
2.0 \\
8.3 \\
2.9 \\
5.9 \\
0.2\end{array}$ & $\begin{array}{r}34.2 \\
6.4 \\
14.9 \\
18.8 \\
0.8 \\
1.4 \\
4.7 \\
0.9 \\
0.4 \\
0.7 \\
8.8\end{array}$ \\
\hline 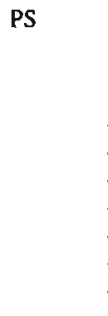 & $\begin{array}{l}16: 0 \\
18: 0 \\
18: 1(n-9) \\
18: 2(n-6) \\
20: 2(n-6) \\
20: 3(n-6) \\
20: 4(n-6) \\
20: 5(n-3) \\
22: 4(n-6) \\
22: 5(n-3) \\
22: 6(n-3)\end{array}$ & $\begin{array}{r}5.2 \\
35.1 \\
14.5 \\
10.8 \\
0.9 \\
3.8 \\
3.5 \\
0.0 \\
5.2 \\
4.6 \\
6.6\end{array}$ & $\begin{array}{r}7.4 \\
34.5 \\
11.2 \\
8.5 \\
4.1 \\
5.1 \\
6.0 \\
0.3 \\
6.7 \\
5.2 \\
8.1\end{array}$ & $\begin{array}{r}2.3 \\
40.5 \\
15.3 \\
10.5 \\
0.6 \\
4.2 \\
4.9 \\
0.0 \\
4.5 \\
4.5 \\
6.8\end{array}$ & $\begin{array}{r}6.1 \\
29.1 \\
31.3 \\
5.5 \\
0.8 \\
2.1 \\
1.6 \\
0.0 \\
4.3 \\
3.1 \\
4.1\end{array}$ & $\begin{array}{r}7.8 \\
32.2 \\
8.9 \\
23.9 \\
4.2 \\
2.8 \\
1.8 \\
0.3 \\
5.3 \\
2.9 \\
3.1\end{array}$ & $\begin{array}{r}8.7 \\
32.1 \\
12.7 \\
5.8 \\
0.5 \\
1.7 \\
7.4 \\
0.0 \\
22.7 \\
0.0 \\
1.0\end{array}$ & $\begin{array}{r}5.0 \\
35.6 \\
13.0 \\
8.3 \\
0.4 \\
1.7 \\
1.0 \\
3.0 \\
1.5 \\
22.0 \\
1.2\end{array}$ & $\begin{array}{r}7.8 \\
37.1 \\
13.1 \\
11.5 \\
0.8 \\
3.1 \\
1.9 \\
0.2 \\
0.8 \\
0.0 \\
16.7\end{array}$ \\
\hline . & $\begin{array}{l}16: 0 \\
18: 0 \\
18: 1(n-9) \\
18: 2(n-6) \\
20: 2(n-6) \\
20: 3(n-6) \\
20: 4(n-6) \\
20: 5(n-3) \\
22: 4(n-6) \\
22: 5(n-3) \\
22: 6(n-3)\end{array}$ & $\begin{array}{r}2.9 \\
34.0 \\
6.9 \\
7.8 \\
0.5 \\
2.9 \\
30.7 \\
0.1 \\
2.7 \\
1.8 \\
1.6\end{array}$ & $\begin{array}{r}7.3 \\
32.7 \\
4.0 \\
4.1 \\
0.4 \\
2.7 \\
36.0 \\
0.1 \\
2.5 \\
1.9 \\
1.9\end{array}$ & $\begin{array}{r}1.7 \\
39.6 \\
3.3 \\
4.6 \\
0.4 \\
1.7 \\
35.5 \\
0.2 \\
2.5 \\
1.1 \\
1.9\end{array}$ & $\begin{array}{r}1.8 \\
29.7 \\
19.5 \\
4.9 \\
0.4 \\
2.2 \\
26.4 \\
0.1 \\
2.7 \\
1.2 \\
1.2\end{array}$ & $\begin{array}{r}2.2 \\
33.0 \\
4.8 \\
21.7 \\
2.1 \\
2.6 \\
21.6 \\
0.1 \\
3.0 \\
0.4 \\
1.0\end{array}$ & $\begin{array}{r}2.9 \\
32.2 \\
5.8 \\
3.3 \\
0.2 \\
0.9 \\
40.7 \\
0.0 \\
6.2 \\
0.0 \\
0.2\end{array}$ & $\begin{array}{r}1.9 \\
35.4 \\
5.5 \\
5.0 \\
0.3 \\
2.0 \\
22.9 \\
13.9 \\
0.3 \\
8.5 \\
0.1\end{array}$ & $\begin{array}{r}2.3 \\
35.0 \\
5.2 \\
7.5 \\
0.5 \\
2.4 \\
32.2 \\
0.4 \\
1.1 \\
0.0 \\
5.9\end{array}$ \\
\hline . & $\begin{array}{l}16: 0 \\
18: 0 \\
18: 1(n-9) \\
18: 2(n-6) \\
20: 2(n-6) \\
20: 3(n-6) \\
20: 4(n-6) \\
20: 5(n-3) \\
22: 4(n-6) \\
22: 5(n-3) \\
22: 6(n-3)\end{array}$ & $\begin{array}{r}5.7 \\
16.5 \\
11.8 \\
9.4 \\
1.0 \\
2.0 \\
20.6 \\
0.4 \\
8.1 \\
5.3 \\
7.2\end{array}$ & $\begin{array}{r}8.3 \\
13.3 \\
6.7 \\
5.7 \\
0.1 \\
2.1 \\
26.0 \\
0.5 \\
9.5 \\
6.8 \\
7.6\end{array}$ & $\begin{array}{r}2.7 \\
21.3 \\
6.5 \\
5.9 \\
0.3 \\
1.9 \\
27.0 \\
0.8 \\
8.2 \\
4.0 \\
8.2\end{array}$ & $\begin{array}{r}5.5 \\
14.2 \\
33.4 \\
5.5 \\
0.7 \\
1.3 \\
11.2 \\
0.2 \\
7.7 \\
4.4 \\
6.3\end{array}$ & $\begin{array}{r}6.3 \\
16.2 \\
9.2 \\
22.4 \\
6.0 \\
1.8 \\
10.6 \\
0.4 \\
9.3 \\
1.5 \\
5.8\end{array}$ & $\begin{array}{r}4.7 \\
19.0 \\
8.7 \\
4.4 \\
0.5 \\
1.2 \\
22.8 \\
0.0 \\
27.1 \\
0.0 \\
1.2\end{array}$ & $\begin{array}{r}4.0 \\
19.0 \\
10.0 \\
7.1 \\
0.4 \\
1.1 \\
4.9 \\
16.5 \\
3.1 \\
24.0 \\
1.2\end{array}$ & $\begin{array}{r}4.7 \\
18.7 \\
8.2 \\
6.4 \\
0.5 \\
1.3 \\
12.3 \\
0.9 \\
1.5 \\
0.0 \\
33.9\end{array}$ \\
\hline $\begin{array}{l}\text { Tolal } \\
\text { PL }\end{array}$ & $\begin{array}{l}16: 0 \\
18: 0 \\
18: 1(n-9) \\
18: 2(n-6) \\
20: 2(n-6) \\
20: 3(n-6) \\
20: 4(n-6) \\
20: 5(n-3) \\
22: 4(n-6) \\
22: 5(n-3) \\
22: 6(n-3)\end{array}$ & $\begin{array}{c}21.1 \\
13.3 \\
17.5 \\
14.9 \\
1.3 \\
1.8 \\
11.4 \\
0.3 \\
3.8 \\
2.9 \\
3.5\end{array}$ & $\begin{array}{r}25.3 \\
12.7 \\
10.7 \\
11.3 \\
0.7 \\
2.4 \\
16.0 \\
0.4 \\
4.1 \\
3.1 \\
4.4\end{array}$ & $\begin{array}{r}9.4 \\
23.4 \\
16.9 \\
13.9 \\
0.4 \\
0.1 \\
16.8 \\
0.4 \\
3.2 \\
3.0 \\
3.8\end{array}$ & $\begin{array}{r}16.5 \\
10.2 \\
37.0 \\
8.6 \\
0.8 \\
1.1 \\
6.7 \\
0.1 \\
3.4 \\
2.2 \\
2.7\end{array}$ & $\begin{array}{r}18.7 \\
11.3 \\
7.0 \\
33.3 \\
5.2 \\
1.7 \\
5.8 \\
0.3 \\
3.8 \\
1.6 \\
2.1\end{array}$ & $\begin{array}{r}22.3 \\
12.7 \\
11.5 \\
8.8 \\
0.6 \\
1.3 \\
18.8 \\
0.1 \\
13.8 \\
0.5 \\
0.5\end{array}$ & $\begin{array}{r}23.5 \\
14.9 \\
12.2 \\
11.4 \\
0.4 \\
0.9 \\
3.9 \\
10.4 \\
0.7 \\
11.3 \\
0.5\end{array}$ & $\begin{array}{r}22.0 \\
14.1 \\
12.5 \\
12.5 \\
0.6 \\
1.4 \\
8.3 \\
1.0 \\
1.0 \\
1.1 \\
15.3\end{array}$ \\
\hline
\end{tabular}




\section{Previous page:}

APPENDIX A: Fatty acid compositions of the phospholipid classes of differently modified endothelial cells.

Endothelial cells were cultured from passage 2 to 4 in media supplemented with various fatty acid sodium salts $(200 \mu \mathrm{M})$ as indicated. Fatty acid compositions of phospholipid classes were determined as described in Experimental Procedures. Only the major fatty acids are shown. Data are expressed as molar percentage of total fatty acids in a phospholipid class. Standard deviations did not exceed $12 \%$ of mean value, $n=3$.

APPENDIX B: Fatty acid compositions of the ethanolamine phospholipid subclass of differently modified endothelial cells

Fatty acid supplemented to culture medium

\begin{tabular}{|c|c|c|c|c|c|c|c|c|}
\hline & & & & & & & & \\
\hline $\begin{array}{l}\text { EP } \\
\text { subclass }\end{array}$ & Fatty acid & None & $18: 0$ & $18: 1$ & $18: 2$ & $20: 4$ & $20: 5$ & $22: 6$ \\
\hline Diacyl & $16: 0$ & 6.7 & 2.5 & 5.5 & 7.7 & 7.8 & 7.0 & 6.4 \\
\hline $\mathrm{EP}$ & 18:0 & 22.0 & 37.9 & 18.3 & 24.1 & 28.3 & 32.0 & 29.1 \\
\hline & $18: 1(n-9)$ & 14.0 & 10.0 & 43.7 & 8.4 & 11.1 & 15.5 & 11.2 \\
\hline & $18: 2(n-6)$ & 11.0 & 8.2 & 7.4 & 26.6 & 5.8 & 11.1 & 9.0 \\
\hline & $20: 2(n-6)$ & 0.8 & 0.4 & 0.6 & 7.6 & 0.6 & 0.0 & 0.6 \\
\hline & $20: 3(n-6)$ & 2.0 & 2.1 & 0.6 & 2.2 & 1.3 & 0.0 & 1.5 \\
\hline & $20: 4(n-6)$ & 18.8 & 19.7 & 7.1 & 6.7 & 20.6 & 4.7 & 9.6 \\
\hline & $20: 5(n-3)$ & 0.3 & 0.6 & 0.1 & 0.0 & 0.0 & 13.5 & 1.3 \\
\hline & $22: 4(n-6)$ & 6.8 & 5.1 & 4.7 & 6.6 & 20.2 & 0.0 & 1.2 \\
\hline & $22: 5(n-3)$ & 4.7 & 3.5 & 1.4 & 2.4 & 0.0 & 13.0 & 1.0 \\
\hline & $22: 6(n-3)$ & 6.5 & 6.2 & 3.8 & 3.4 & 0.0 & 0.0 & 24.6 \\
\hline Plasmalogen & $16: 0$ & 6.5 & 1.3 & 5.0 & 2.5 & 2.9 & 2.9 & 1.9 \\
\hline EP & $18: 0$ & 8.1 & 2.6 & 3.3 & 2.5 & 5.7 & 3.9 & 3.6 \\
\hline & $18: 1(n-9)$ & 3.3 & 1.5 & 9.2 & 1.6 & 3.3 & 3.2 & 2.7 \\
\hline & $18: 2(n-6)$ & 4.1 & 1.8 & 2.7 & 11.7 & 1.7 & 2.7 & 2.1 \\
\hline & $20: 2(n-6)$ & 0.0 & 0.0 & 0.1 & 1.7 & 0.0 & 0.1 & 0.0 \\
\hline & $20: 3(n-6)$ & 0.1 & 0.8 & 1.4 & 0.5 & 0.4 & 0.5 & 0.3 \\
\hline & $20: 4(n-6)$ & 36.9 & 46.2 & 27.2 & 27.8 & 35.7 & 3.2 & 18.8 \\
\hline & $20: 5(n-3)$ & 0.0 & 0.0 & 0.0 & 0.0 & 0.0 & 29.8 & 2.8 \\
\hline & $22: 4(n-6)$ & 15.6 & 17.0 & 20.5 & 25.2 & 44.8 & 3.6 & 4.3 \\
\hline & $22: 5(n-3)$ & 10.8 & 11.0 & 11.4 & 10.1 & 1.5 & 43.5 & 2.4 \\
\hline & $22: 6(n-3)$ & 14.6 & 15.4 & 17.1 & 15.5 & 2.1 & 1.9 & 57.6 \\
\hline
\end{tabular}

Procedure as in appendix A. In one experiment also the EP subclass compositions of plasmalogen EP and diacyl EP were analysed. Diacyl EP contains also alkyl-acyl EP $(<0.5 \%$ of total PL). Only the major fatty acids are shown. Data are expressed as molar percentage of total fatty acids in a EP subclass. It should be noted that the values of plasmalogen EP represent only the fatty acid composition at the $\mathrm{sn}-2$ position, in contrast to the values of diacyl EP which are derived from the sn-1 plus sn-2 position. 
Chapter 4

Influence of Fatty Acid Modification on Complement Induced Prothrombinase Activity and PMA Induced von Willebrand Factor Release of Endothelial Cells

Renée C.R.M. Vossen, Maria C.E. van Dam-Mieras,

Gerard Hornstra, Jan A. van Mourik, and Robert F.A. Zwaal. 


\begin{abstract}
The membrane fatty acid composition of endothelial cells can be modified extensively by long-term culturing in fatty acid modified media. In order to study if fatty acid modifications may influence cellular membrane related processes, we investigated complement induced endothelial prothrombinase activity and PMA induced von Willebrand Factor (vWF) release in various fatty acid modified endothelial cells. The results indicated no influence of fatty acid modification on complement induced prothrombinase activity. However, PMA induced vWF release was found to be increased in cells modified with arachidonic acid compared to unmodified or other fatty acid modified cells. It is suggested that extensive fatty acid modification may not interfere with the physicochemical properties involved in membrane processes required to form procoagulant microvesicles, although considerable changes in arachidonic acid content may affect protein kinase $\mathrm{C}$ and/or eicosanoid mediated cellular reactions required for vWF release.
\end{abstract}




\section{Introduction}

Complement induced cytolysis of microorganisms forms part of the inflammatory processes. In addition, deposition of the terminal complement proteins C5b-9 on homologous blood and vascular cell membranes has been shown to induce the nonlytic activation of a variety of cell responses. For example, human C5b-9 proteins are known to activate intracellular protein kinases and to stimulate the secretory degranulation of human platelets and endothelial cells, leading to factor $\mathrm{V}$ and von Willebrand Factor (vWF) release, respectively $[1,2]$. In addition, C5b-9 stimulation induces transbilayer migration of membrane phospholipids and exposure of a catalytic surface for assembly of the prothrombinase enzyme complex. This is accompanied by plasma membrane vesiculation and microparticle formation in both cell types $[3,4]$. These processes seem to be mediated by extracellular $\mathrm{Ca}^{2+}$ influxes, which increase intracellular $\mathrm{Ca}^{2+}$ levels, by activation of intracellular protein kinase $\mathrm{C}$, but not initially by mobilizing internal $\mathrm{Ca}^{2+}$ pools [1]. Several $\mathrm{Ca}^{2+}$ mobilizing agonists such as thrombin and A23187 but also PMA, a protein kinase C activator, are able to mimick some of these processes and can induce vWF release and membrane vesiculation to a lower extent [4]. On the other hand, C5b-9 inhibitory proteins (CD59) are found to be expressed at the plasma membrane surface and are able to protect endothelial cells and platelets from stimulatory effects arising from complement activation [5].

Complement mediated cytolysis was reported to be influenced partially by the physical state of the lipid bilayer (membrane fluidity) and also by agents known to affect membrane lipid synthesis and turnover $[6,7,8]$. It was found that changes in membrane lipid composition, such as increased unsaturated fatty acid and cholesterol contents, decreased the sensitivity of Acholeplasma laidlawii and sheep erythrocytes to complement-mediated cytolysis [6,7]. It would be of interest to know if considerable changes in the fatty acid composition of endothelial cell membranes influence the cell responses induced by nonlytic complement activation. For example, variations in the expression of prothrombinase activity by differently fatty acid modified cells may be important in hemostatic processes.

Endothelial cells are able to synthesize and store vWF. The cells are found to release vWF continuously into the medium and extracellular matrix (constitutive release) without stimulation. However, stimulated release of vWF from their storage pools (Weibel Palade bodies) into the medium is induced by thrombin, A23187 and PMA and is mediated by influx of extracellular $\mathrm{Ca}^{2}+[9,10]$. This process requires membrane fusion and is accompanied by the appearance of P-selectin (or GMP-140, a storage granule membrane protein and adherence receptor for leukocytes) at the endothelial surface, which stimulates leukocyte adherence [2]. The stimulated release of $v W F$ by endothelial cells may play an important role in hemostatic and inflammatory processes and 
therefore it is of interest to study if this vWF release is influenced by the changes in membrane fatty acid composition.

We have previously developed an in vitro method for extensive fatty acid modification of endothelial cells during long-term culture in fatty acid supplemented media. This allowed us to study the influence of fatty acid modification on various cellular functional properties, that may be important in hemostatic and inflammatory processes. In order to study if considerable alterations in membrane fatty acid composition may influence cellular membrane related processes, we investigated the complement induced endothelial prothrombinase activity and the PMA induced vWF release in our long-term fatty acid modified cells. The results show no influence of fatty acid modification on prothrombinase activity, whereas stimulated $\mathrm{VWF}$ release was increased in arachidonic acid modified cells.

\section{Materials and Methods}

Culture media M199 and RPMI 1640 (with L-glutamine and 20 mM HEPES) and $2.5 \%(\mathrm{w} / \mathrm{v})$ trypsin solution were obtained from Flow Lab (Bioggio, Switzerland). Tissue culture dishes $\left(60 \mathrm{~cm}^{2}\right.$ (F3003)) were from Falcon (Etten Leur, The Netherlands). 6-well and 48-well culture plates were from Costar (Cambridge, England). EDTA, HEPES and L-glutamine were obtained from Serva (Heidelberg, Germany). Free fatty acids and their sodium salts, phorbol myristate acetate (PMA), and fatty acid free human serum albumin were obtained from Sigma (St. Louis, MO, USA). A23187 was from Calbiochem. All chemicals used were of the highest grade of purity available.

Buffers used were: phosphate buffered saline containing $\mathrm{NaCl}(0.137 \mathrm{M})$, $\mathrm{KCl}(2.6 \mathrm{mM}), \mathrm{Na}_{2} \mathrm{HPO}_{4}(8.1 \mathrm{mM}), \mathrm{KH}_{2} \mathrm{PO}_{4}(1.15 \mathrm{mM}) \mathrm{pH}$ 7.4; Hank's buffer containing $\mathrm{NaCl}(0.137 \mathrm{M}), \mathrm{KCl}(6.8 \mathrm{mM}), \mathrm{CaCl}_{2} .2 \mathrm{H}_{2} \mathrm{O}(1.3 \mathrm{mM}), \mathrm{MgSO}_{4} .7 \mathrm{H}_{2} \mathrm{O}$ $(0.8 \mathrm{mM}), \mathrm{Na}_{2} \mathrm{HPO}_{4} .2 \mathrm{H}_{2} \mathrm{O}(0.45 \mathrm{mM}), \mathrm{KH}_{2} \mathrm{PO}_{4}(0.45 \mathrm{mM})$, HEPES $(10 \mathrm{mM}) \mathrm{pH}$ 7.2; Trypsin solution contained $0.125 \%(\mathrm{w} / \mathrm{v})$ trypsin in phosphate buffered saline containing EDTA $(0.33 \mathrm{mM})$. The standard culture medium consisted of $20 \%$ human serum in M199/RPMI1640 (1:1, v/v) supplemented with Lglutamine $(2 \mathrm{mM})$, gentamicin $(50 \mathrm{mg} / \mathrm{ml}), \mathrm{NaHCO}_{3}(11.9 \mathrm{mM})$ and endothelial cell growth supplement $(100 \mu \mathrm{g}$ protein/ml) as described before [11]. Thrombin, prothrombin, Xa and Va were purified as described elsewere [12]. Rabbit antihuman endothelial cell IgG, C8 deficient human serum and the complement proteins were a kind gift from Dr. P.J. Sims (The Blood Research Institute, Milwaukee, USA).

\section{Endothelial cell culture and modification of the fatty acid composition}

Human umbilical vein endothelial cells were isolated from umbilical cord veins and cultured in standard culture medium containing 20\% human serum (pool of at least 200 healthy donors) as described previously [11]. For modification of the endothelial cell fatty acid composition, the cells were cultured in various fatty acid supplemented media from passage 2 to 4 ( 7 or 8 days). The fatty acid 
supplemented media ( $200 \mu \mathrm{M}$ final concentration) were prepared by addition of a particular fatty acid sodium salt to warm human serum $\left(37^{\circ} \mathrm{C}\right)$ prior to addition of culture medium as described previously [11].

\section{Complement activation of endothelial cells}

Unmodified or fatty acid modified endothelial cells at passage 4 were grown to confluency in 48 -well culture plates $\left(1 \mathrm{~cm}^{2}\right.$ well). Endothelial cells were incubated with complement as described by Hamilton et al. [4]. Briefly, the cell monolayers were washed 4 times with Hank's buffer containing $0.5 \%$ human serum albumin (buffer A) and incubated with rabbit anti-endothelial cell IgG (5 $\mathrm{mg} / \mathrm{ml}$ ) at room temperature for $15 \mathrm{~min}$. The cells were washed once and incubated with $25 \% \mathrm{C} 8$-deficient serum (dilluted in buffer A) at $37^{\circ} \mathrm{C}$ for 10 $\mathrm{min}$. The monolayers were then washed twice at $4^{\circ} \mathrm{C}$ and incubated with $125 \mu \mathrm{l}$ C8 and C9 (fresly prepared in buffer A) at $37^{\circ} \mathrm{C}$ for $15 \mathrm{~min}$., followed by addition of $200 \mu \mathrm{l}$ buffer $\mathrm{A}$ and assay of prothrombinase activity.

Confluent endothelial cells in 48-well culture plates after 4 times washing with buffer A were also activated with $125 \mu$ thrombin $(10 \mathrm{nM})$ or A23187 (10 $\mu \mathrm{M})$ for $5 \mathrm{~min}$., or with PMA $(50 \mathrm{ng} / \mathrm{ml})$ for $15 \mathrm{~min}$. followed by addition of 200 $\mu \mathrm{l}$ buffer $\mathrm{A}$ and assay of prothrominase activity.

\section{Assay of prothrombinase activity}

Prothrombinase activity was measured as described previously [13] with minor modifications. Briefly, after incubation of confluent endothelial mono layers with agonist and adaption of volume to $325 \mu \mathrm{l}$ in 48-well plates, $50 \mu \mathrm{l}$ of $\mathrm{Va}$ and $\mathrm{Xa}(6 \mathrm{nM}$ and $3 \mathrm{nM}$ final concentration in buffer $\mathrm{A}$ ) were added and incubated at $37^{\circ} \mathrm{C}$ for $3 \mathrm{~min}$. Then the reaction was initiated by addition of 125 $\mu \mathrm{l}$ of prothrombin (16 $\mu \mathrm{M}$ final concentration). After exactly $4 \mathrm{~min}$. incubation at $37^{\circ} \mathrm{C}, 50 \mu \mathrm{l}$ aliquots were taken and transferred to a cuvette containing $1 \mathrm{ml}$ of $0.1 \mathrm{M} \mathrm{NaCL}, 50 \mathrm{mM}$ Tris-HCl, $2 \mathrm{mM}$ EDTA (pH 7.9) to terminate the reaction. Thrombin activity was measured at $405 \mathrm{~nm}$ using the chromogenic substrate S2238 (Kabi Vitrum, Stockholm, Sweden). The concentrations of Va, Xa and prothrombin were chosen such that the rate of thrombin generation was limited by the amount of catalytical membrane surface ( PS exposure) exposed.

\section{Endothelial cell $\nu W F$ release}

Unmodified or fatty acid modified endothelial cells at passage 4 were grown to confluency in 6-well culture plates. The cell monolayers were washed 3 times with RPMI1640 containing $0.5 \%$ human serum albumin (buffer B) or with buffer A. After $30 \mathrm{~min}$. cells were incubated with $1.5 \mathrm{ml} \mathrm{PMA}(50 \mathrm{ng} / \mathrm{ml})$ o: buffer. $500 \mu \mathrm{l}$ aliquots were taken after a 15, 30 and $60 \mathrm{~min}$. incubation (from separate wells) and were centrifuged to remove floting cells and frozen. vWF was determined by an immunoradiometric assay according to Ruggeri et al. [14] with some modifications, including the use of monoclonal antibodies against $\mathrm{vWF}$ [15]. Normal human plasma from a pool of 40 donors, containing $10 \mu \mathrm{g}$ of vWF per ml, was used as a standard. The Mann-Whitney test was used for statistical analysis. 


\section{Results}

Effect of fatty acid modification on complement induced prothrombinase activity

We first examined the expression of endothelial cell prothrombinase activity induced by exposure of the cells to various calcium mobilizing agonists in unmodified endothelial cells. After preliminary experiments, the incubation times of the agonists were chosen at $5 \mathrm{~min}$. for thrombin and A23187 and $15 \mathrm{~min}$. for PMA and complement proteins. As shown in table 1, endothelial cell prothrombinase activity differed with the agonist used. Incubation of endothelial cells with thrombin, PMA and calcium ionophore A23187 resulted in a relatively small increase in prothrombinase activity ( $51-138 \%$ ) relative to that of unstimulated control cells. However, deposition of the complement complex C5b-9 on the endothelial surface resulted in a 5 fold increase in endothelial prothrombinase activity (table 1). This response was found only after addition of $\mathrm{C} 8$ and $\mathrm{C} 9$, since cells exposed to IgG alone or C5b67 hardly showed an increase in prothrombinase activity (fig. 1). The time course of prothrombinase activity for different amounts of C8 in the presence of excess $\mathrm{C} 9$ is shown in fig. 2 , indicating the dependence of prothrombinase activity on the amount of C5b-9 complexes formed at the endothelial cell surface and the influence of incubation time.

In order to investigate if fatty acid modification of endothelial cell membranes would influence the complement induced prothrombinase activity, cells were cultured with various supplemented fatty acids for 7-8 days. As was shown previously, this induced gross changes in fatty acid composition $[11,16]$, without serious alterations of membrane unsaturation, phospholipid distribution and cholesterol content. After C5b-9 deposition on the endothelial surface, prothrombinase activity of all cells was increased, but was hardly altered by the fatty acid modification (fig. 3 ). In addition, $25-30 \%$ release of LDH was measured in the complement stimulated cells. A23187 induced prothrombinase activity was also not influenced by the fatty acid composition of the endothelial cells (data not shown).

Effect of fatty acid modification on PMA induced endothelial cell $v W F$ release

In order to study if endothelial $\mathrm{VWF}$ release was influenced by membrane fatty acid modification, constitutive and PMA induced vWF release of long-term fatty acid modified cells was measured in time (15, 30 , and $60 \mathrm{~min}$.) as shown in fig. 4 . While the constitutive release of vWF into the culture medium remained low, the stimulated vWF release was increased in time starting after more than $15 \mathrm{~min}$. of incubation with PMA and continued to increase after $60 \mathrm{~min}$. of PMA stimulation. 
Table 1. Induction of endothelial cell prothrombinase activity by various agonists

\begin{tabular}{lcc}
\hline Agonist & $\begin{array}{c}\text { thrombin formation } \\
(\mathrm{nM} / \mathrm{min})\end{array}$ & $\begin{array}{c}\text { increase above } \\
\text { control(\%) }\end{array}$ \\
\hline none & $16.0 \pm 5.0$ & \\
thrombin $(10 \mathrm{nM})$ & $24.2 \pm 3.6$ & $51 \pm 6.5$ \\
PMA $(50 \mathrm{ng} / \mathrm{ml})$ & $28.9 \pm 6.2$ & $81 \pm 8.3$ \\
A23187 $(10 \mu \mathrm{M})$ & $38.0 \pm 2.8$ & $138 \pm 7.6$ \\
C5b-9 & $96.3 \pm 17.4$ & $502 \pm 24.8$ \\
\hline
\end{tabular}

Human umbilical vein endothelial cells were incubated with thrombin or A23187 for 5 min. and with PMA or C5b-9 (2 and $16 \mu \mathrm{g} / \mathrm{ml}$ of C8 and $\mathrm{C}$, respectively) for $15 \mathrm{~min}$. prior to measurement of prothrombinase activity as described under materials and methods. Data are mean value $\pm S D, n=3$, from one experiment representative of 2 so performed.

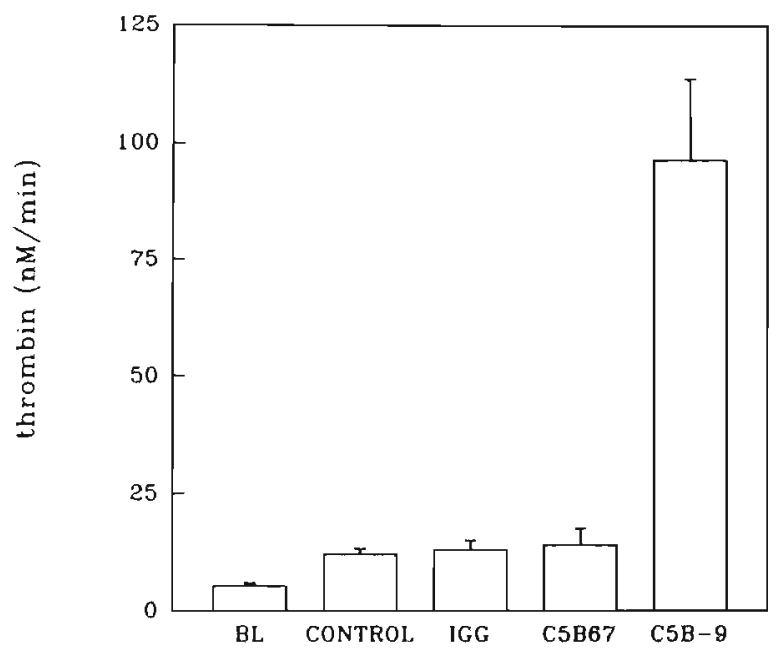

Fig. 1. Endothelial cell prothrombinase activity induced by complement treatment. Unmodified endothelial cells were exposed to complement stimulation for $15 \mathrm{~min}$. followed by measurement of prothrombinase activity as described under materials and methods. Abbreviations: bl, thrombin generation in the absence of cells; control, thrombin generation of untreated cells; $\mathrm{IgG}$, cells incubated with anti-endothelial cel] IgG alone; C5b67, cells incubated with IgG and C8-deficient serum; C5b-9, C5b67 cells incubated with $\mathrm{C} 8$ and $\mathrm{C} 9(1$ and $16 \mu \mathrm{g} / \mathrm{ml}$ final concentration). Data are mean value \pm $\mathrm{SD}, \mathrm{n}=3$, from one experiment representative of 2 so performed. 


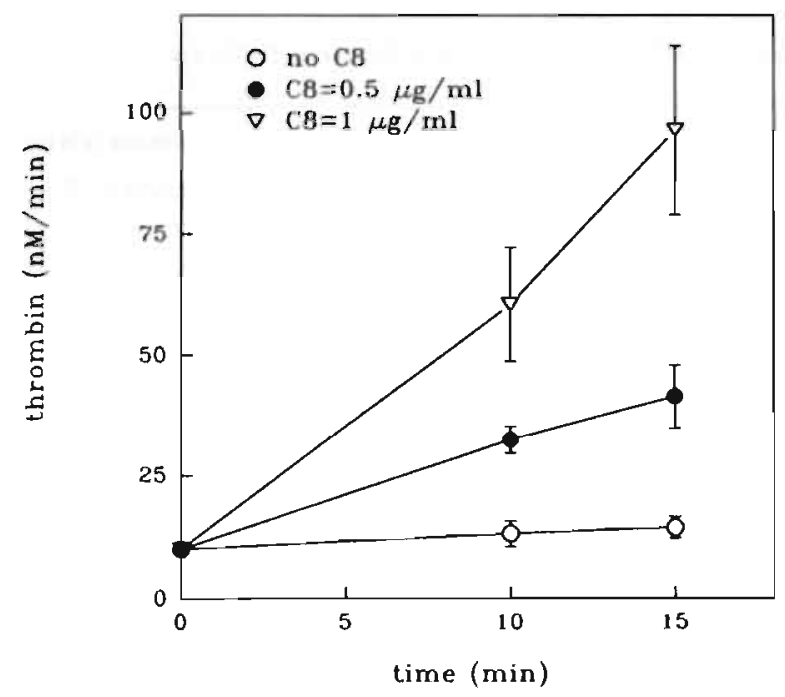

Fig. 2. Time course of prothrombinase activity induced by various amounts of $C 8$. Prothrombinase activity was measured in time after complement treatment of unmodified endothelial cells in the presence of excess $C 9(16 \mu \mathrm{g} / \mathrm{ml})$ and $0,0.5$ or $1 \mu \mathrm{g} / \mathrm{ml} \mathrm{C} 8$ as described under materials and methods. Data are mean values $\pm S D, n=3$, from a single experiment.

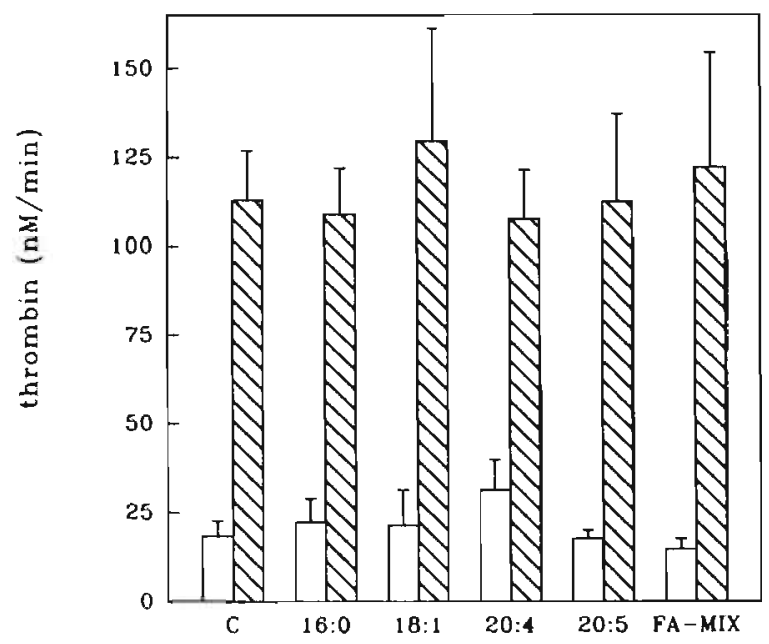

Fig. 3. Complement induced prothrombinase activity of endothelial cells modified with different fatty acids. Endothelial cells, long-term modified with various fatty acids, were treated with complement proteins ( 1 and $16 \mu \mathrm{g} / \mathrm{ml}$ of $\mathrm{C} 8$ and $\mathrm{C} 9$, respectively) and prothrombinase activity was measured as described under materials and methods. Thrombin generation of untreated or complement treated cells is depicted. Abbreviations: C, unmodified control cells; $16: 0,18: 1,20: 4,20: 5$, cells modified with $200 \mu \mathrm{M}$ palmitic, oleic, arachidonic, or eicosapentaenoic acid, respectively; FA-mix, cells modified with $200 \mu \mathrm{M}$ fatty acid mixture with a fatty acid composition comparable to that in human serum [10]. Data are mean value $\pm S D$, from 4 experiments each performed in triplicate. 
No influence of fatty acid modification on constitutive release was found, whereas the PMA induced vWF release was significantly increased only in cells modified with arachidonic acid (20:4(n-6)) after 60 min incubation, compared to unmodified cells. After $30 \mathrm{~min}$. incubation already a small but not significant increase was found. Stimulated vWF release of cells modified with other fatty acids was comparable to that of unmodified cells. To a lesser extent the same phenomenon was found with thrombin stimulation (data not shown).

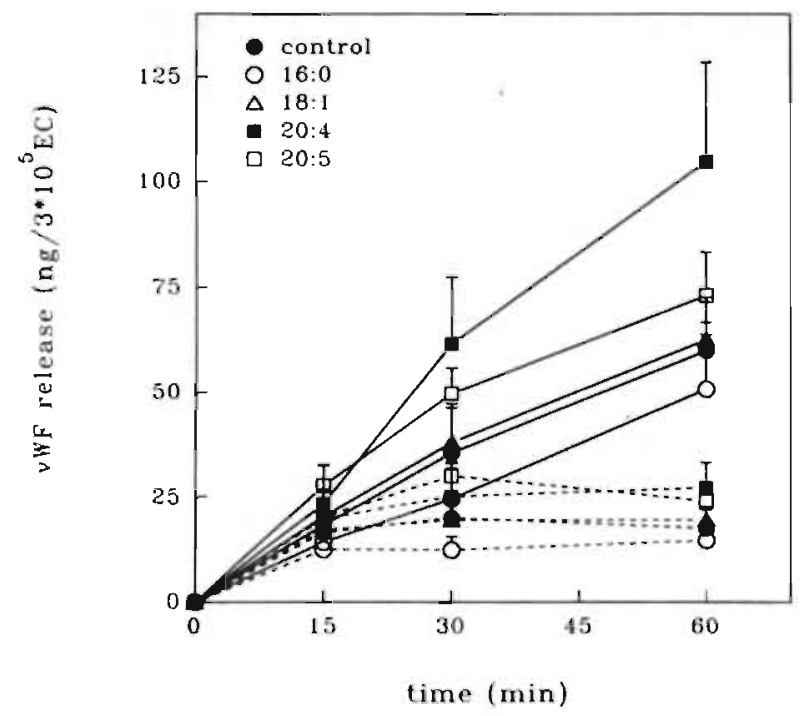

Fig. 4. PMA induced $\nu W F$ release of endothelial cells modified with different fatty acids. Endothelial cells, long-term modified with various fatty acids, were either not stimulated (dotted line) or stimulated with PMA (straight line), and VWF release was measured at the indicated time points as described under materials and methods. Abbreviations as in fig. 3. Data are mean value \pm SEM of 3 to 5 experiments.

\section{Discussion}

We studied the influence of considerable alterations in membrane fatty acid composition on cellular membrane related processes. Endothelial prothrombinase activity induced by complement, thrombin, A23187 and PMA stimulation and PMA induced vWF release were measured in our long-term fatty acid modified cells. Both processes are attended by membrane "fusion" events, either to form procoagulant microvesicles or to allow secretion of vWF to occur. These fusion phenomena may be influenced by the lipid composition of the membrane (fatty acid composition and unsaturation, cholesterol content). It has been demonstrated before [17] that increased prothrombinase activity on cells treated with 
the $\mathrm{Ca}^{2+}$ ionophore $\mathrm{A} 23187$ can be correlated with an increase in the number of negatively charged phospholipids available for factor $\mathrm{Va}$ binding to the cell surface, due to transbilayer migration of phosphatidylserine to the outer leaflet of the plasma membrane, presumably triggered by increased cytosolic $\mathrm{Ca}^{2+}$. Also, the increased prothrombinase activity on C5b-9 treated cells may be attributed to the increased exposure of acidic phospholipids on endothelial cells and the cell derived microvesicles to form a catalytic surface for assembly of the prothrombinase enzyme complex $[1,4]$. The present results show that induction of prothrombinase activity by different stimuli is not influenced by long-term fatty acid modification of endothelial cell membranes, suggesting that the phospholipid fatty acid composition does not influence the extent of transbilayer migration of phosphatidylserine and the formation of endothelial cell derived microvesicles. The effects of membrane lipid composition on complement mediated cytolysis of Acholeplasma Laidlawii reported by others $[7,8]$ were due to changes in cholesterol content and membrane unsaturation, which influenced membrane fluidity. Taking into account that our long-term fatty acid modification considerably changes the fatty acid compositions but hardly alters membrane cholesterol content, phospholipid composition and average saturated and unsaturated fatty acid content of the endothelial cells $[11,16]$, this may explain why no influence of fatty acid modification was found in our long-term fatty acid modified cells. These results support and extent previous observations [11] indicating careful 'homeostatic' control of membrane related functional processes in our fatty acid modified endothelial cells, notwithstanding considerable changes in fatty acid composition.

Stimulation of endothelial cells with PMA, complement proteins and other $\mathrm{Ca}^{2+}$ mobilizing agonists initiates intracellular signal transduction processes, such as increasing intracellular $\mathrm{Ca}^{2+}$, activation of protein kinase $\mathrm{C}$, activation of phospholipases $\mathrm{A}_{2}$ and $\mathrm{C}$, with mobilization of arachidonic acid, diacylglycerol and inositol phosphates [18]. The terminal complement proteins $\mathrm{C} 5 \mathrm{~b}-9$ are known to activate protein kinase $\mathrm{C}$ and increase intracellular $\mathrm{Ca}^{2+}$ by selectively increasing the permeability of the plasma membrane for $\mathrm{Ca}^{2+}$ without directly affecting the structural or functional integrity of internal membranes [1]. PMA is a potent protein kinase $\mathrm{C}$ activator and stimulates arachidonic acid mobilization by phospholipase $A_{2}$ [20]. These processes among others result in release of $\mathrm{VWF}$ from the endothelial cell internal Weibel-Pallade bodies. The present results show that in cells modified with arachidonic acid the PMA induced $\mathrm{VWF}$ release is increased compared to that of unmodified or other fatty acid modified cells, while constitutive release remains unaltered. This indicates a selective influence of the cellular fatty acid composition on stimulated $\mathrm{vWF}$ release for cells with a considerably increased arachidonic acid content. At present, we have no straightforward explanation for this phenomenon. After stimulation, the release 
of VWF may be increased due to either secretion of more storage granules or to the presence of more VWF in the secreted storage granules. During the long-time culture of the endothelial cells in the presence of supplemented arachidonic acid the synthesis and storage of vWF might be increased. On the other hand, as protein kinase C, phospholipase A2 and arachidonic acid are involved in membrane fusion processes [18], and protein kinase $C$ activity is influenced by arachidonic acid $[19,21]$, these results suggest that protein kinase $C$ mediated processes may be influenced by extensive arachidonic acid modification of endothelial cells. However, more data including protein kinase $\mathrm{C}$ activation and inhibition are needed to get more insight into the actual mechanism.

In conclusion, when studying cellular membrane related processes, no influence of fatty acid modification on prothrombinase activity was found, whereas stimulated vWF release was selectively increased in arachidonic acid modified cells. While the data suggest that extensive fatty acid modification does not interfere with the physicochemical properties involved in membrane processes required to form procoagulant microvesicles, it cannot be excluded that considerable changes in arachidonic acid content may affect protein kinase $\mathrm{C}$ and/or eicosanoid mediated cellular reactions required for $\mathrm{vWF}$ release. The actual mechanism and significance of this phenomenon, however, remain to be explored.

\section{Acknowledgement}

The authors want to thank Peter Sims and Therese Wiedmer (The Blood Research Institute, Milwaukee, USA) for helpful discussions and the generous gift of rabbit anti-human endothelial cell IgG, C8 deficient human serum and the complement proteins C8 and C9, Herman-Jan Brinkman (CLB, amsterdam) for the measurements of von Willebrand factor, the department of Obstetrics and Gynaecology (The Wever Hospital, Heerlen) for supply of umbilical cords and the Red Cross Bloodbank Limburg (Maastricht) for supply of human serum.

\section{References}

1 Wiedmer, T., Ando, B., and Sims, P.J. 1987. Complement C5b-9-stimulated platelel secretion is associated with a $\mathrm{Ca}^{2+-i n i t i a t e d ~ a c t i v a t i o n ~ o f ~ c e l l u l a r ~ p r o t e i n ~ k i n a s e s . ~ J . ~ B i o l . ~ C h e m . ~}$ 262, 13674-13681

2 Hattori, R., Hamition, K.K., McEver, R.P., and Sims, P.J. 1989. Comptement proleins C5b-9 induce secretion of high molecular weight multimers of endothelial von Willebrand Factor and translocation of granule membrane protein GMP-140 to the cell surface. J. Biol. Chem. 264, $9053-9060$

3 Van der Meer, W.B., Fugate, R.D., and Sims, P.J. 1989. Complement proteins C5b-9 induce transbilayer migration of membrane phospholipids. Biophys. J. 56, 935-946

4 Hamitton, K.K, Hattori, R., Esmon, C.T., Sims, P.J. 1990. Complement proteins C5b-9 induce vesiculation of the endothelial plasma membrane and expose catalytic surface for assembly of the prothrombinase enzyme complex. J. Biol. Chem. 265, 3809-3814

5 Rolins, S.A., and Sims, P.J. 1990. The complement-inhibilory activity of CD59 resides in its capacity to block incorporation of C9 into membrane C5b-9. J. Immun. 144, 3478-3483 
6 Shin, M.L., Paznekas, W.A., and Mayer, M.M. 1978. On the mechanism of membrane damage of complement: The effect of length and unsaturation of the acyl chains in tiposomal bilayers and the effect of cholesterol concentration in sheep erythrocyte and liposomal membranes. J. Immun. 120, 1996-2002

7 Dahl, J.S., Dahl, C.E., and Levine, R.P. 1979. Role of lipid fatty acid composition and membrane fluidity in the resistance of Acholeplasma laidlawii to complement-mediated killing. J. Immun. 123, 104-108

8 Papadimitriou, J.C., Carney, D.F., and Shin, M.L. 1991. Inhibitors of membrane lipid metabolism enhance complement-mediated nucleated cell killing through distinct mechanisms. Mol. Immun. 28, 803-809

9 Loesberg, C., Gonsalves, M.D., Zandbergen, J., Willems, C., van Aken, W.G., Stel, H.V., van Mourik, J.A., and de Groot, P.G. 1983. The effect of calcium on the secretion of factor VIII-related antigen by cuhured human endothelial cells. Biochim. Biophys. Acta 763, 160168

10 Haudin, R.I., Wagner, D.S. 1989. Molecular and cellular biology of von Willebrand factor. in: Progress in Hemostasis and Thrombosis (Coller, B.S. and Saunders, C., eds.) V9, pp. 233259

11 Vossen, R.C.R.M., Dam-Mieras, M.C.E. van, Lemmens, P.J.M.R., Hornstra, G., and Zwaal, R.F.A. 1991. Membrane fatty acid composilion and endothelial cell functional properties. Biochim. Biophys. Acta 1083, $243-251$

12 Rosing, J., van Rijn, J.L.M.L., Bevers, E.M., van Dieijen, G., Comfunus, P. and Zwaal, R.F.A. 1985. The role of activated human platelets in prothrombin and factor $X$ activation. Blood 65, 319-322

13 Comfurius, P., Senden, J.M.G., Tilly, R.H.J., Schroit, A.J., Bevers, E.M., and Zwaal, R.F.A. 1990. Loss of membrane phospholipid asymmetry in platelets and red cells may be associated with calcium-induced shedding of plasma membrane and inhibition of amino phospholipid translocase. Biochim. Biophys. Acta 1026, 153-160

14 Ruggeri, Z.M., Mannucci, P.M., Jeffcoate, S.L., and Ingram, G.I.C. 1976. Immunoradiometric assay of factor VIII-related antigen, with obsevations in 32 patients with von Willebrand disease. Brit. J. Haematol. 33, 221-232

15 Stel, H.V., Sakariassen, K.S., Scholte, B.J., Veerman, E.C.I., van der Kwast, T.H., de Groot, P., Sixma, J.J., and van Mourik, J.A. 1984. Characterisation of 25 monoclonal antibodies to factor VIII-von Willebrand factor: relationship between ristocetin-induced platelet aggregation and platelet adherence to subendothelium. Blood 63, 1408-1415

16 Vossen, R.C.R.M., Feijge, M.A.H., Heemskerk, J.W.M., Dam-Mieras, M.C.E. van, Hornstra, G., and Zwaal, R.F.A. 1993. Long-term fatty acid modification of endothelial cells: implications for arachidonic acid distribution in phospholipid classes. J. Lipid Res., in press

17 Comfurius, P. Bevers, E.M., and Zwaal, R.F.A. 1985. The involvement of cytoskeleton in the regulation of transbilayer movement of phospholipids in human blood platelets. Biochim. Biophys. Acta 815, 143-148

18 Lelkes, P.I., and Pollard H.B. 1991. Cytoplasmic determinants of exocytotic membrane fusion. in: Membrane fusion (Wilschut, J. and Hoekstra, D., eds.) Marcel Dekker Inc. New York, pp. 511-551

19 Whatley, R.E., Zimmerman, G.A., Mclntyre, T.M., and Prescott, S.M. 1990. Lipid metabolism and signal transduction in endothelial cells. Prog. Lipid Res. 29, 45-63

20 Zavoico, G.B., Hrolich, J.K., Gimbrone, M.A.Jr., and Schafer, A.I. 1990. Enhancement of thrombin- and lonomycin-stimulated prostacyclin and platelet-activating factor production in cultured endothelial cells by a lumor-promoting phorbol ester. J. Cell. Physiol. 143, 596605

21 Shinomura, T., Asaoka, Y., Oka, M. Yoshida, K., and Nishizuka, Y. 1991. Synergistic action of diacylglycerol and unsaturated fatty acid for protein kinase $C$ activation: its possible implications. Proc. Natl. Acad. Sci. USA. 88, 5149-5153

22 Morgan, B.P. 1989. Complement membrane attack on nucleated cells: resistance, recovery and non-lethal effects. Biochem. J. 264, 1-14

23 Schâfer, H., Mathey, D., Hugo, F., and Bhakdi, S. 1986. Deposition of the terminal C5b-9 complement complex in infarcted areas of human myocardium. J. Immunol. 137, 19451949

24 Wiedmer, T., and Sims, P.J. 1991. Participation of protein kinases in complement C5b-9induced shedding of platelet plasma membrane vesicles. Blood 78, 2880-2886

25 Wiedmer, T., Ando, 8., and Sims, P.J. 1987. Complement C5b-9-stimulated platelet secretion is associated with a $\mathrm{Ca}^{2+-i n i t i a t e d ~ a c t i v a t i o n ~ o f ~ c e l l u l a r ~ p r o t e i n ~ k i n a s e s . ~ J . ~ B i o l . ~}$ Chem. 262, 13674-13681 
Chapter 5

Continuous Monitoring of Lipid Peroxidation by measuring Conjugated Diene Formation in an Aqueous Liposome Suspension

Renée C.R.M. Vossen, Maria C.E. van Dam-Mieras, Gerard Hornstra, Robert F.A. Zwaal. 


\begin{abstract}
A method is described for direct and continuous monitoring of lipid peroxidation in an aqueous suspensions of sonicated liposomes. By means of UV difference spectroscopy using tandem cuvettes, the formation of conjugated dienes during liposome peroxidation is followed. Using this technique the effect of the fatty acid composition of liposomes on lipid peroxidation is studied. The results show that both the extent and the time scale of lipid peroxidation are influenced by the fatty acid composition of the phospholipid liposomes. This is confirmed also by other methods, such as measurement of the formation of lipid hydroperoxides and measurement of the decrease of polyunsaturated fatty acids. The advantage of this method is the direct and continuous monitoring of phospholipid peroxidation in an aqueous environment, without subsampling and extraction of peroxidation products into organic solvents.
\end{abstract}




\section{Introduction}

Lipid peroxidation has been defined as the oxidative deterioration of polyunsaturated lipids by free radical reactions [1]. In biological membranes the polyunsaturated fatty acids are very susceptible to lipid peroxidation, which therefore has been suggested to be involved in various physiological and pathological phenomena such as the formation of local messengers (prostaglandins) during tissue activation, cellular ageing, radiation damage, mutagenesis, carcinogenesis, and atherogenesis [1-4] Radical chain reactions involving polyunsaturated fatty acids cause an initial rearrangement of double bonds leading to conjugated diene formation. Upon subsequent reaction with oxygen, lipid hydroperoxide is formed, which readily decomposes into numerous products including malondialdehyde.

Many methods for measuring lipid peroxidation have been developed $[1,3]$. Lipid peroxidation is usually investigated by measurement of the major initial peroxidation products (conjugated dienes, lipid hydroperoxides) and of minor breakdown products (malondialdehyde, hexanal, volatile hydrocarbons) [3]. As proteins and DNA may interfere with accurate determination of the lipid peroxidation capacity, lipids are usually extracted from tissues or cells prior to measurement of peroxidation.

The methods commonly used for determining conjugated dienes are based on measurement of their absorption at 233-236 $\mathrm{nm}[3,5,6]$. It is important to realize that in these determinations the accuracy is limited by the fact that the diene absorption appears as a rather imprecise shoulder on the strong absorption peak of the unperoxidized fatty acid itself. This is especially relevant when small amounts of conjugated dienes have to be determined. By using second derivative spectra the sensitivity can be increased [7]. These methods, however, usually involve discontinuous end point analyses in organic solvents. Therefore, we developed a method to monitor liposome peroxidation continuously in an aqueous environment, based on the method for monitoring low density lipoprotein peroxidation described by Esterbauer et al. [8]. We introduced the use of tandem cuvettes to measure the formation of conjugated dienes in an aqueous environment by UV difference spectroscopy. Lipid liposomes were used as a model membrane system to study lipid peroxidation in an aqueous environment [2]. Using this technique we also studied the influence of the liposome fatty acid composition on lipid peroxidation profiles. The results were compared with other methods for monitoring lipid peroxidation, such as the formation of lipid hydroperoxides and the decrease of polyunsaturated fatty acids. 


\section{Materials and Methods}

1-palmitoyl-2-palmitoleoyl-sn-glycerophosphocholine (C16:0/C16:1 PC), 1stearoyl-2-oleoyl-sn-glycerophosphocholine (C18:0/C18:1 PC), 1-palmitoyl-2linoleoyl-sn-glycero-phosphocholine (C16:0/C18:2 PC), 1-stearyl-2-arachidonoyl-sn-glycerophosphocholine (C18:1/C20:4 PC) and butylated hydroxytoluene were purchased from Sigma (St Louis, MO, USA). dilinoleoyl-snglycerophosphocholine (diC18:2 PC), dilinolenoyl-sn-glycero-phosphocholine (diC18:3 PC) and diarachidonoyl-sn-glycerophosphocholine (diC20:4 PC) were from Applied Science Laboratories Inc. (Penna, USA). Hydrogenperoxide (30\% solution) was from Baker B.V. (Deventer, The Netherlands). $\mathrm{CuSO}_{4}$ was from Merck (Darmstadt, Germany). All other reagents were of the highest grade of purity available.

The susceptibility for peroxidation of different lipid samples was determined by measuring conjugated diene formation in an aqueous environment according to an adaptation of the method described by Esterbauer [8] for low density lipoprotein. In our setup we introduced sonicated liposomes and tandem cuvettes with UV difference spectroscopy. Lipid liposomes were peroxidized by $200 \mu \mathrm{M} \mathrm{CuSO}_{4}$ and $2 \mathrm{mM} \mathrm{H}_{2} \mathrm{O}_{2}$ (peroxidation conditions characterised earlier by Kuypers et al. [9]) and the UV spectrum was monitored continuously by difference spectroscopy using tandem cuvettes $(2 \mathrm{~cm}, 232 \mathrm{QS}$, Hellma B.V., The Hague, The Netherlands). Absorption spectra were recorded on a Uvikon 860 spectrophotometer applied with data handling equipment (Kontron Instruments, Zürich, Switserland). UV difference spectra (205-300 nm) were recorded every 5 minutes for the time indicated. By using the curve overlay option, curves were plotted in one figure.

For the preparation of the sonicated liposomes, phospholipids (300-500 nmol) were dried in a glass tube by a stream of nitrogen. In case of diC18:2 PC, diC18:3 PC or diC20:4 PC, these lipids were mixed $1: 1(\mathrm{~mol} / \mathrm{mol})$ with $\mathrm{C} 16: 0 / \mathrm{C} 16: 1 \mathrm{PC}$ in order to obtain $500 \mathrm{nmol}$ phosphatidylcholine giving 500 nmol oxidizable polyunsaturated fatty acid. $1 \mathrm{ml}$ of $50 \mu \mathrm{M}$ trisbuffer $\mathrm{pH} 7.5$ presaturated with nitrogen was added to the dried lipid and a dispersion was made by vortexing under nitrogen. Phospholipid liposomes were prepared by sonication for 10 minutes under nitrogen and cooling with ice.

Prior to the peroxidation experiments, lipid liposomes were diluted 1:5 (vol/vol) in $50 \mu \mathrm{M}$ trisbuffer and $2 \mathrm{ml}$ was added to the first compartment of the tandem cuvettes in both the reference and the sample beam as shown in fig. 1. The second compartments of both tandem cuvettes were filled with $2 \mathrm{ml}$ of 50 $\mu \mathrm{M}$ trisbuffer. The temperature of the cuvettes was kept at $37^{\circ} \mathrm{C}$. The UV difference spectra $(205-300 \mathrm{~nm})$ recorded at this moment showed a straight line. Lipid peroxidation was initiated by addition of $20 \mu \mathrm{l} 200 \mathrm{mM} \mathrm{H}_{2} \mathrm{O}_{2}$ and $20 \mu \mathrm{l}$ $20 \mathrm{mM} \mathrm{CuSO}_{4}$ to the lipid liposomes in the first compartment of the sample cuvette. To correct for the effects of lipid dilution and of adding $\mathrm{H}_{2} \mathrm{O}_{2}$ and $\mathrm{CuSO}_{4}$, the same amounts of $\mathrm{H}_{2} \mathrm{O}_{2}$ and $\mathrm{CuSO}_{4}$ were added to the buffer containing compartment of the reference cuvette, while $40 \mu \mathrm{l}$ of distilled water was added to both the lipid containing compartment of the reference cuvette and the buffer containing compartment of the sample cuvette. UV difference spectra from $205-300 \mathrm{~nm}$ were recorded continuously. The final conditions were $60-100 \mu \mathrm{M}$ phospholipid liposomes, $2 \mathrm{mM} \mathrm{H}_{2} \mathrm{O}_{2}$ and $200 \mu \mathrm{M} \mathrm{CuSO}$. In this setup the formation of conjugated dienes (233-235 nm) in the sample cuvette was measured against the nonperoxidized lipids in the reference 
cuvette. By this experimental design the contributions of changes in the liposome, $\mathrm{CuSO}_{4}$ and $\mathrm{H}_{2} \mathrm{O}_{2}$ concentrations to the difference spectra were ruled out. The method allows for a sensitive and continuous registration of conjugated dienes in an aqueous environment, without the necessity of subsampling and extraction of the peroxidation products formed.
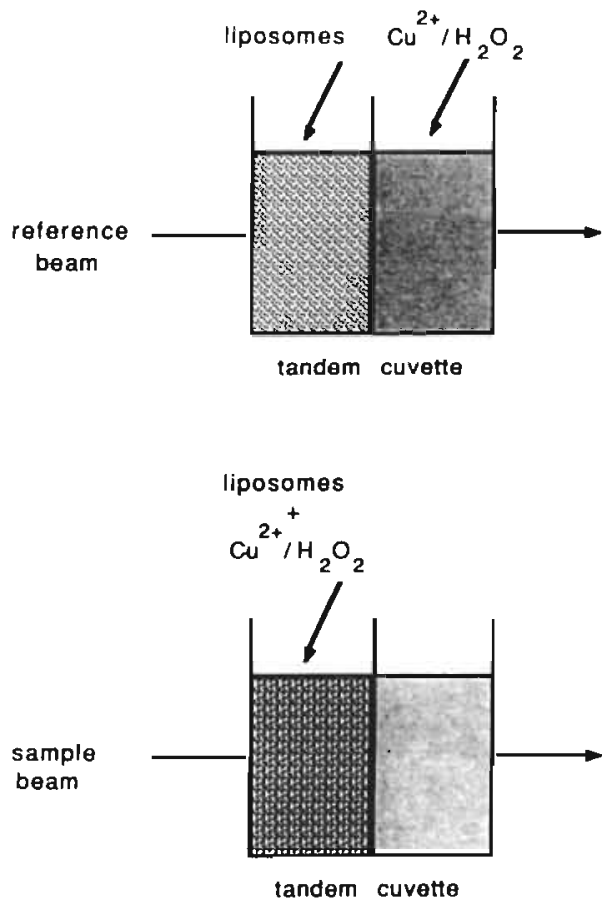

Fig. 1. UV difference spectroscopy using tandem cuvettes for monitoring peroxidation of phospholipid liposomes. Peroxidation was started in the sample cuvette by addition of $\mathrm{CuSO}_{4}$ and $\mathrm{H}_{2} \mathrm{O}_{2}$ to the liposomes. In the reference cuvette no liposome peroxidation was initiated as $\mathrm{CuSO}_{4}$ and $\mathrm{H}_{2} \mathrm{O}_{2}$ were added to a separate compartment. The difference spectra were recorded continuously.

Lipid hydroperoxides were determined by the iodometric assay described by Hicks et al. [10], and the decrease in polyunsaturated fatty acids due to lipid peroxidation was determined by gas-liquid chromatography as described earlier [11]. Lipids were extracted from endothelial cell membranes by the method of Bligh et al. using butylated hydroxy toluene (BHT) as an antioxidant [12] and phospholipids were separated from neutral lipids by thin-layer chromatography as described before, but BHT in the organic solvents was omitted [11]. Phosphorus content of phospholipids was quantified according to Böttcher at al. [13]. 

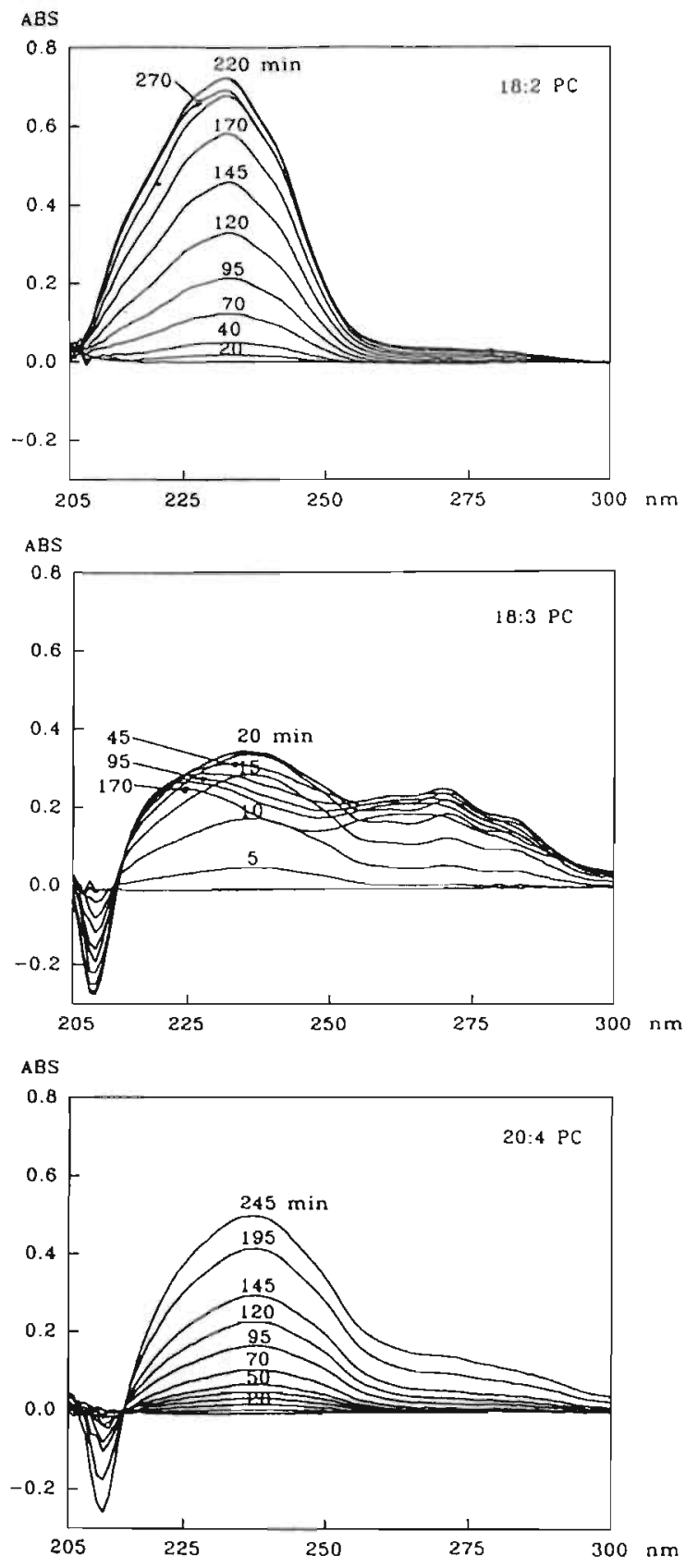

Fig. 2. Change of the UV difference spectrum of phosphatidylcholine liposomes with different fatty acid compositions during peroxidation. Liposomes $(100 \mu \mathrm{M})$ prepared from A) C18:2 PC, B) C18:3 PC, and C) C20:4 PC were peroxidized by $\mathrm{CuSO}_{4}(200$ $\mu \mathrm{M})$ and $\mathrm{H}_{2} \mathrm{O}_{2}(2 \mathrm{mM})$. Conjugated diene formation was monitored continuously by UV difference spectroscopy (205-300 nm) using tandem cuvettes. Peroxidation profiles were shown as UV absorption units (ABS) against wavelength (nm) for the time points indicated. 


\section{Results and Discussion}

Peroxidation profiles of phosphatidylcholine liposomes with different fatty acid compositions

We studied the influence of fatty acid composition on the peroxidation profiles of phosphatidylcholine liposomes by UV difference spectroscopy. The peroxidation profiles of C18:2 PC, C18:3 PC and C20:4 PC are shown in fig. 2. Peroxidation of C18:2 PC resulted in an absorption maximum at $234 \mathrm{~nm}$, which first increased in time and then gradually decreased representing the formation and decomposition of conjugated dienes. The absorption maximum at $234 \mathrm{~nm}$ of C18:3 PC shifted in time towards $225 \mathrm{~nm}$ with the concomitant appearance of a dip at $210 \mathrm{~nm}$. This shift may be explained by formation of alkenals and hydroxyalkenals, typical products of lipid peroxidation with absorption maxima at 220-225 nm [4]. Two other absorption maxima at 270 and $280 \mathrm{~nm}$ were observed, which probably represent formation of conjugated trienes [4]. The conjugated triene formation started later than the conjugated diene formation and was lower. C20:4 PC showed a comparable peroxidation profile, but with a slower time scale and without distinct maxima at 270 and $280 \mathrm{~nm}$, probably because a mixture of conjugated trienes is formed to a lesser extent. Surprisingly, after $250 \mathrm{~min}$. of peroxidation still no decrease of conjugated diene formation was seen for $\mathrm{C} 20: 4 \mathrm{PC}$.

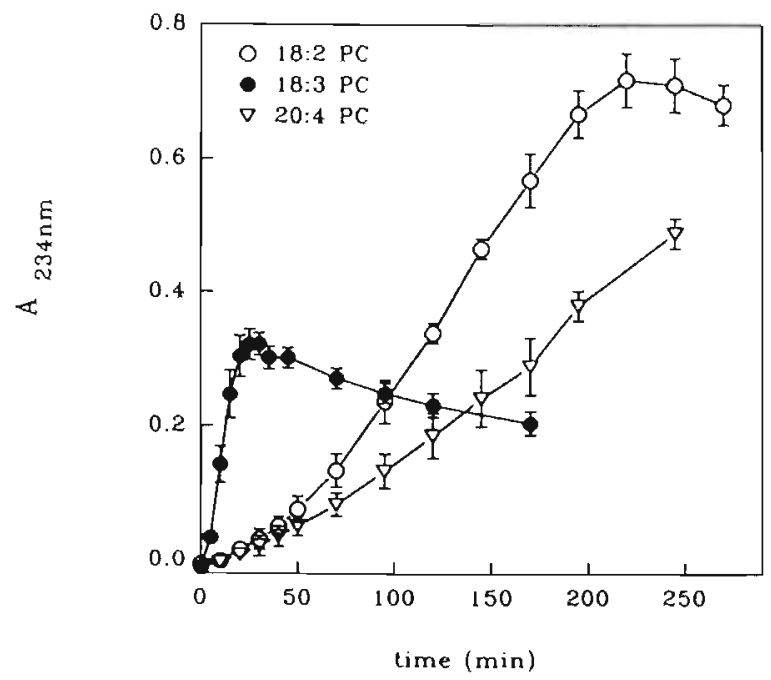

Fig. 3. Time scale of conjugated diene formation of phosphatidylcholine liposomes with different fatty acid compositions during peroxidation. Procedure as in fig. 2 . UV absorption at $234 \mathrm{~nm}$ (conjugated diene formation) was plotted against peroxidation time. The mean values $\pm S D$ of 5 separate liposome preparations measured on 3 different days are shown. 
The fatty acid composition of the liposomes thus considerably influenced the peroxidation profile (fig. 2) as well as the time scale of the peroxidation process and the maximal extent of conjugated diene formation (fig. 3). C18:3 PC showed a rapid but relatively low conjugated diene formation, while that of $\mathrm{C} 18: 2 \mathrm{PC}$ was slower but relatively high. C20:4 PC showed a slow but progressive formation of conjugated dienes. The peroxidation profiles and maximal extent of conjugated diene formation in our system give reproducible results with standard deviations below 6\%. The initial conjugated diene formation after relatively short peroxidation times is more variable, possibly dependent on the presence of pre-existing lipid peroxides in the samples used. Taking into account the molar absorption coefficient for conjugated dienes $\left(\varepsilon=29,500 \mathrm{M}^{-1} \mathrm{~cm}^{-1}[1]\right)$, the maximal conjugated diene formation was $0.243 \pm 0.011 \mathrm{nmol} / \mathrm{nmol}$ fatty acid and $0.125 \pm 0.006 \mathrm{nmol} / \mathrm{nmol}$ fatty acid for C18:2 PC and C18:3 PC respectively.

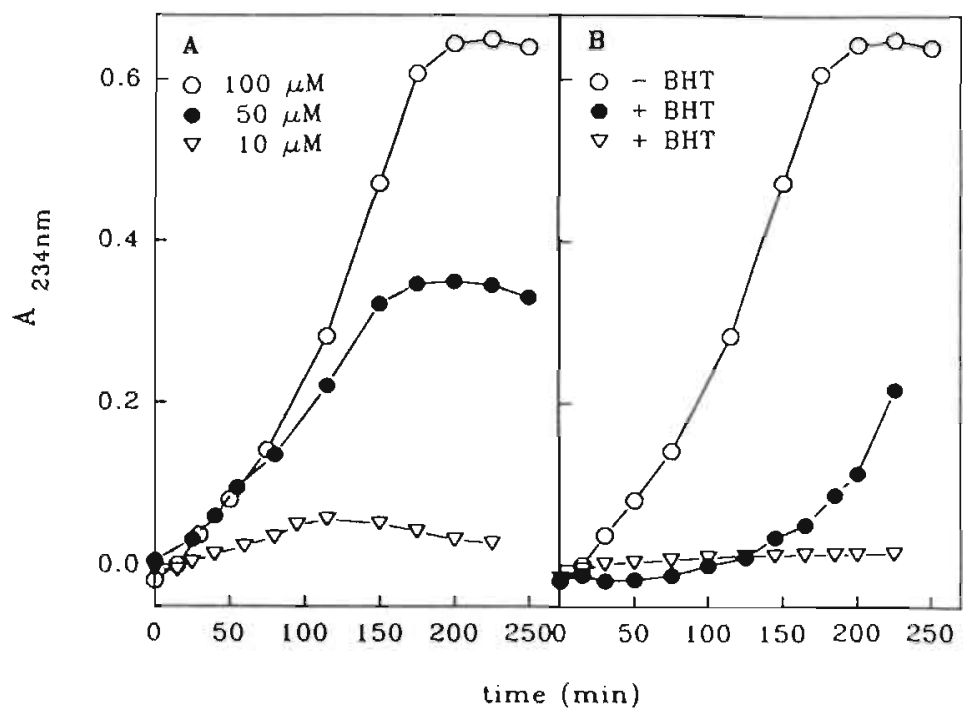

Fig. 4. Influence of liposome concentration and butylated hydroxytoluene on conjugated diene formation. Procedure as in fig. 2. Fig. 4A shows the conjugated diene formation during peroxidation of C18:2 PC liposomes of a final concentration of respectively 10 $\mu \mathrm{M}, 50 \mu \mathrm{M}$ or $100 \mu \mathrm{M}$. In fig. $4 \mathrm{~B}$ the influence of butylated hydroxytoluene $(0.05 \mathrm{nmol}$ BHT/nmol 18:2 PC for closed circles and 0.5 nmol BHT/nmol C18:2 PC for open triangles) on the peroxidation of $100 \mu \mathrm{M} \mathrm{C18:2} \mathrm{PC} \mathrm{was} \mathrm{shown.}$

We also studied the influence of liposome concentration on the lipid peroxidation process (fig. 4). It can be seen in fig. 4A that there is a linear relationship between the maximal amount of conjugated dienes formed and the amount of $\mathrm{C} 18: 2 \mathrm{PC}$ liposomes present during peroxidation. Addition of lower amounts of $\mathrm{CuSO}_{4} / \mathrm{H}_{2} \mathrm{O}_{2}$ also resulted in a lower extent of lipid peroxidation, while addition of $\mathrm{CuSO}_{4}$ or $\mathrm{H}_{2} \mathrm{O}_{2}$ alone 
resulted in a much slower time scale of peroxidation (data not shown). Addition of the antioxidant BHT to the liposomes during preparation resulted in a lag phase at low BHT concentrations, while total inhibition of lipid peroxidation occurred with higher amounts of BHT (fig. 4B). Similar effects of liposome, $\mathrm{CuSO}_{4} / \mathrm{H}_{2} \mathrm{O}_{2}$ and $\mathrm{BHT}$ concentrations were also found with C18:3 PC and C20:4 PC. We also measured the UV absorption spectra of known amounts of a standard fatty acid derived conjugated diene. When 13-hydroxy-9,11-octadecaenoic acid was used as a standard reference of conjugated dienes, the absorption at $234 \mathrm{~nm}$ showed a linear increase with increasing amounts of 13-hydroxy-9,11octadecaenoic acid (data not shown), with a molar absorption coefficient of $\varepsilon=28,550 \mathrm{M}^{-1} \mathrm{~cm}^{-1}$. This value was comparable to those reported by others $[1,8]$. The data summarized above show that indeed the formation of conjugated dienes by lipid peroxidation is measured in our system using UV spectroscopy, liposomes and tandem cuvettes.

As expected, no formation of conjugated dienes was observed with liposomes consisting of $\mathrm{C} 16: 0 / \mathrm{C} 16: 1 \mathrm{PC}$ or $\mathrm{C} 18: 0 / \mathrm{C} 18: 1 \mathrm{PC}$. When we recorded peroxidation profiles of diC18:2 PC 1:1 mixed with C16:0/C16:1 PC, no differences were found with that of C16:0/C18:2 PC. In both liposome preparations the amount of oxidizable linoleic acid is equal. These observations suggest that only the polyunsaturated fatty acids are peroxidized, within the timescale measured, and that the amount but not the position of the polyunsaturated fatty acid within the phospholipid molecule influences lipid peroxidation in liposomes.

Comparison of the continuous conjugated diene measurement with other discontinuous methods for estimating lipid peroxidation in vitro

We compared our conjugated diene measurement with other lipid peroxidation assays, such as measurement of the decrease of polyunsaturated fatty acids by gas-liquid chromatography and measurement of the lipid hydroperoxide amounts by the iodometric assay. As a more physiological lipid source, we used phospholipids which were extracted from endothelial cell membranes with different fatty acid compositions. These fatty acid modified endothelial cells were cultured as described before [11]. Liposomes $(60 \mu \mathrm{M}$ phospholipid) were prepared from endothelial phospholipids with A) a normal fatty acid composition, B) an increased oleic acid content, C) an increased linoleic acid and arachidonic acid content, or D) an increased eicosapentaenoic acid and docosahexaenoic acid content. The liposomes were peroxidized for 80 minutes with $2 \mathrm{mM}$ $\mathrm{H}_{2} \mathrm{O}_{2}$ and $200 \mu \mathrm{M} \mathrm{CuSO}_{4}$ (final concentrations) and conjugated diene formation was measured continuously. As an example fig. 5a shows the peroxidation profile of liposomes prepared from endothelial cells with a normal fatty acid composition and fig. 5b shows that of liposomes with increased oleic acid content. Both difference spectra obtained during peroxidation showed characteristics of the C20:4 PC and C18:2 PC 

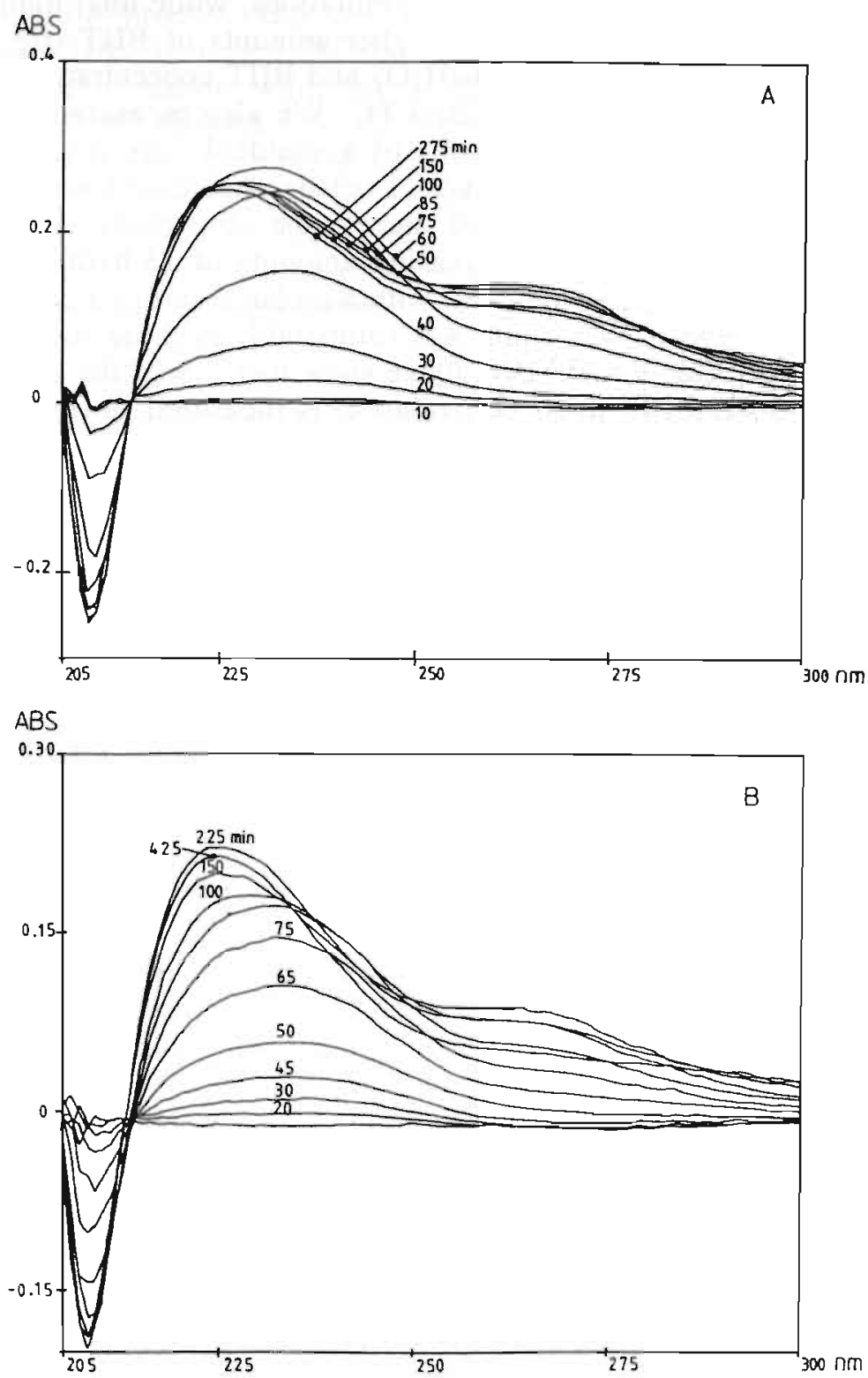

Fig. 5. Change of the UV difference spectrum during peroxidation of liposomes prepared from endothelial cell phospholipids. Phospholipids were extracted from endothelial cells with normal fatty acid composition (fig. 5A) or with increased oleic acid content (fig. 5B) and liposomes were prepared. Peroxidation with $\mathrm{CuSO}_{4}$ and $\mathrm{H}_{2} \mathrm{O}_{2}$ was monitored by UV difference spectroscopy as in fig. 2 . 
spectra (fig. 2). This was to be expected for cellular phospholipids having a mixture of various fatty acids, because phosphatidylcholine comprises $53.4 \%$ of total phospholipids and linoleic acid and arachidonic acid are the most abundant polyunsaturated fatty acids in these endothelial cells [11]. Fig 5 shows that the extent of conjugated diene formation in liposomes with increased oleic acid content was decreased compared to liposomes with normal fatty acid composition. As was shown earlier [11], the polyunsaturated fatty acid content of the membrane phospholipids was decreased when the oleic acid content increased: endothelial cell phospholipids with normal fatty acid composition contained $16.4 \%$ oleic acid, $14.5 \%$ linoleic acid and $10.7 \%$ arachidonic acid, while cells modified with oleic acid contained $33.7 \%$ oleic acid, $7.6 \%$ linoleic acid and $6.3 \%$ arachidonic acid in the membrane phospholipids. This means that smaller amounts of linoleic acid and arachidonic acid were available for the formation of conjugated dienes in these liposomes, as oleic acid itself cannot form conjugated dienes.

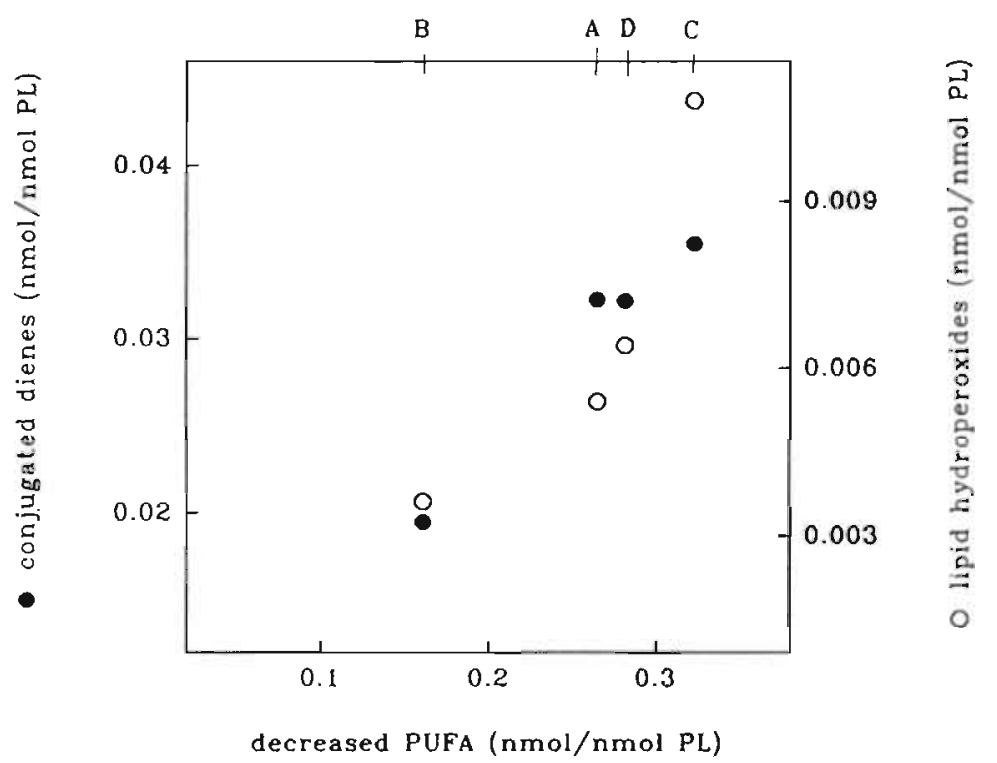

Fig. 6. Comparison of conjugated diene formation and lipid hydroperoxide formation with the decrease of polyunsaturated fatry acids during lipid peroxidation. Phospholipids were extracted from endothelial cells with different fatty acid compositions: A) cells with normal fatty acid composition, B) cells with increased oleic acid ( $n-9)$ content, C) cells with increased linoleic and arachidonic acid (n-6) content and D) cells with increased eicosapentaenoic and docosahexaenoic acid $(\mathrm{n}-3)$ content. Liposomes $(60 \mu \mathrm{M})$ were prepared and peroxidized for 80 minutes. Conjugated dienes (closed symbols), lipid hydroperoxides (open symbols) and decrease of polyunsaturated fatty acids were measured. For calculation of nanomol conjugated diene formation a molar absorption coefficient $e=29,500 \mathrm{M}^{-1} \mathrm{~cm}^{-1}$ [1] was used. 
In the same batch of endothelial cell derived liposomes, the amount of lipid hydroperoxides formed after 80 minutes of peroxidation was measured. Also the fatty acid compositions of both peroxidized $(80 \mathrm{~min}$.) and nonperoxidized liposomes were determined and the decrease of polyunsaturated fatty acids during peroxidation was calculated. It is shown in fig. 6 that the fatty acid composition of the liposomes influenced the extent of lipid peroxidation as measured by 3 different methods. For example, the extent of lipid peroxidation was decreased when the amount of oleic acid was increased (B) compared to cells with normal fatty acid composition (A). Fig. 6 also shows that there was a rather good correlation between the measurement of conjugated diene formation, the decrease of polyunsaturated fatty acids and the formation of lipid hydroperoxides during 80 minutes peroxidation.

In conclusion, we describe a method for continuously monitoring lipid peroxidation by measuring conjugated diene formation by UV difference spectroscopy using tandem cuvettes and sonicated liposomes. Our method allows a direct and continuous monitoring of phospholipid peroxidation in an aqueous environment, without the disadvantages of subsampling and extraction of peroxidation products into organic solvents. We have shown that the time course and extent of lipid peroxidation are considerably influenced by the fatty acid composition of the phospholipid liposomes. This is confirmed by other methods for measuring lipid peroxidation, such as the decrease of polyunsaturated fatty acids and the formation of lipid hydroperoxides.

\section{Acknowledgements}

The authors wish to acknowledge Carina Pernot for her technical assistance with the lipid hydroperoxide measurements, Mariet Molenaar for typing the manuscript, and Hans van Pelt for helpful discussions.

\section{References}

1 Halliwell, B., and Gutteridge, J.M.C. 1989. Lipid peroxidation: a radical chain reaction. in: Free radicals in biology and medicine, 2nd edn, Oxford University Press, New York, pp. 188-276

2 Chatterjee, N.S., and Aganwal, S. 1988. Liposomes as membrane models for study of lipid peroxidation. Free Rad. Biol. Med. 4, 51-72

3 Slater, T.F. 1984. Overvieuw of methods used for detecting lipid peroxidation. in: Methods Enzymol. (Packer, L., ed.), Vol. 105, pp. 283-293, Academic Press, San Diego

4 Sevanian, A., and Hochstein, P. 1985. Mechanisms and consequences of lipid peroxidation in biological systems. Ann. Rev. Nutr. 5, 365-390

5 Montfoort, A., Bezstarosti, K., Groh, M.M.J., and Metsă-Ketelă, T.J.A. 1987. The influence of the lipid composition on the degree of lipid peroxidation of liposomes. Biochem. Int. 15, 525-543

6 Kim, R.S., and LaBella, F.S. 1987. Comparison of analytical methods for monitoring autoxidation profiles of authentic lipids. J. Lipid Res. 28, 1110-1117 
7 Corongiu, F.P., and Milia, A. 1983. An improved and simple method for determining diene conjugation in autoxidized polyunsaturated fatty acids. Chem. Biol. Interactions 44, 289297

8 Esterbauer, H., Striegl, G., Puhl, H., and Rotheneder, M. 1989. Continuous monitoring of in vitro oxidation of human low density lipoprotein. Free Rad. Res. Comms. 6, 67-75

9 Kuypers, F.A., van den Berg, J. J. M., Schalkwijk, C., Roelołsen, B., and Op den Kamp. J. A. F. 1987. Parinaric acid as a sensitive fluorescent probe for the determination of lipid peroxidation. Biochim. Biophys. Acta 921, 266-274

10 Hicks, M., and Gebicki, J.M. 1979. A spectrophotometric method for the determination of lipid hydroperoxides. Anal. Biochem. 99, 249-253

11 Vossen, R.C.R.M., Dam-Mieras, M.C.E. van, Lemmens, P.J.M.R., Hornstra, G., and Zwaal, R.F.A. 1991. Membrane fatty acid composition and endothelial cell functional activity. Biochim. Biophys. Acta 1083, 243-251

12 Bligh, E.R., and Dyer, W.J. 1959. A rapid method for total lipid extraction and purification. Can. J. Biochem. Physiol. 37, 911-918

13 Bottlcher, C.J.F.,Gent, C.M. van, and Pries, C. 1961. A rapid and sensitive sub-micro phosphorus determination. Anal. Chim. Acta 24, 203-204

14 Mowri, H., Nojima, S., and Inoue, K. 1984. Effect of lipid composition of liposomes on their sensitivity to peroxidation. J. Biochem. 95, 551-558 


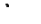


Chapter 6

Differential Effects of Endothelial Cell Fatty Acid Modification on the Sensitivity of their Membrane Phospholipids to Peroxidation

Renée C.R.M. Vossen, Maria C.E. van Dam-Mieras, Gerard Hornstra, Robert F.A. Zwaal.

based on: Am. J. Clin. Nutr. 1993., in press 


\section{Abstract}

In order to study the relationship between the fatty acid composition of human umbilical vein endothelial cells and their susceptibility to oxidative stress, we modified their fatty acid composition by long-term culturing in media supplemented with a saturated, monounsaturated, or polyunsaturated fatty acid. Sensitivity of the cellular phospholipids to peroxidation was monitored by measuring conjugated diene formation induced by $\mathrm{CuSO}_{4}$ and $\mathrm{H}_{2} \mathrm{O}_{2}$ in liposomes prepared from the respective phospholipid extracts. The extent of phospholipid peroxidation was found to increase with increasing content of polyunsaturated fatty acids. In addition, the sensitivity of individual polyunsaturated fatty acids to peroxidation was directly proportional to the number of double bonds present. However, no unequivocal relationship was observed between conjugated diene formation and the unsaturation index (an indicator for the combined effect of number of double bonds and polyunsaturated fatty acid contents of the membrane phospholipids). In fact, the results suggest that longterm fatty acid modification of endothelial cells differentially alters the sensitivity of their membrane phospholipids to peroxidation: modification with oleic acid may protect against lipid peroxidation, whereas linoleic acid may act as a promoter of peroxidation. In contrast to what might be expected, modification with eicosapentaenoic or docosahexaenoic acid does not increase the sensitivity of phospholipids to peroxidation. 


\section{Introduction}

The role of oxidative stress in the development of pathological processes is increasingly emphasized in literature. Injury of cells mediated by reactive oxygen species may contribute to the processes of aging, carcinogenesis, ischemia-reperfusion damage, inflammation and atherosclerosis $[1,2,3]$. During atherogenesis, injury of endothelial cells may be a consequence of local activation of the vascular wall by, for example, inflammatory stimuli [4]. Activated neutrophils can induce endothelial cell damage through the secretion of reactive oxygen species, such as superoxide anion $\left(\mathrm{O}^{2-} \cdot\right)$ and hydrogen peroxide $\left(\mathrm{H}_{2} \mathrm{O}_{2}\right)[5,6]$. Several studies have reported a profound effect of $\mathrm{H}_{2} \mathrm{O}_{2}$ on endothelial cell function: altered prostacyclin release and signal transduction [7,8], ATP depletion [9], elevated $\mathrm{Ca}^{2+}$ levels [10] and DNA strand break formation [11].

The mechanisms by which reactive oxygen species induce injury of endothelial cells are not well understood. Readily oxidizable target molecules for reactive oxygen species are DNA, membrane proteins and the polyunsaturated fatty acids. As endothelial cell membranes contain relatively large amounts of polyunsaturated fatty acids, membrane damage may be induced by lipid peroxidation leading ultimately to cellular injury and death $[1,2]$. The fatty acid composition of endothelial cells can be modified in vitro. In contrast to others [12,13], we modified the fatty acid compositions of endothelial cell membranes by culturing with fatty acid supplemented media for a long period (7-8 days) in order to reach equilibrium distribution of the fatty acids among all lipid classes and subclasses $[14,15]$. This allows us to study to what extent fatty acid modification of endothelial cell phospholipids may influence their sensitivity to peroxidation and, thus, to oxidative injury.

Previous studies have shown that the incubation of pig pulmonary endothelial cells with supplemented fatty acids influenced lipid peroxidation and cellular injury. Supplementation of the cells with polyunsaturated fatty acids increased sensitivity to lipid peroxidation and release of lactate dehydrogenase [12]. In addition, supplementation with saturated or monounsaturated fatty acids made the cells more resistant to lipid peroxidation and cellular injury [12,13]. Other studies using liposome suspensions have reported on the effects of the fatty acid, phospholipid and cholesterol compositions on the extent of lipid peroxidation [16-19]. However, the effects of $n-3$ polyunsaturated fatty acids on lipid peroxidation of endothelial cell membranes have not been very well documented. Endothelial cells, n-3 fatty acids and reactive oxygen species are all supposed to be involved in the pathogenesis of atherosclerosis in either a stimulatory or an inhibitory way. In this study we modified human umbilical vein endothelial cells with saturated, monounsaturated and $n-6$ 
or n-3 polyunsaturated fatty acids. We investigated the sensitivity to lipid peroxidation of phospholipids, extracted from the fatty acid modified endothelial cells, by following conjugated diene formation with UV difference spectroscopy [16].

In general, the results of this study suggest that long-term fatty acid modification of endothelial cells alters the sensitivity of their membrane phospholipids to peroxidation: modification with oleic acid may protect against lipid peroxidation, whereas linoleic acid may act as a promoter. Contrary to what might be expected, modification with eicosapentaenoic or docosahexaenoic acid does not increase the sensitivity to lipid peroxidation compared to unmodified cells.

\section{Materials and methods}

Culture media M199 and RPMI1640 (with L-glutamine and $20 \mathrm{mM}$ HEPES) and $2.5 \%(\mathrm{w} / \mathrm{v})$ trypsin solution were obtained from Flow Lab (Bioggio, Switzerland). Tissue culture dishes $\left(60 \mathrm{~cm}^{2}\right.$ (F3003)) were from Falcon (Etten Leur, The Netherlands). EDTA, HEPES and L-glutamine were obtained from Serva (Heidelberg, Germany). Free fatty acids and their sodium salts were obtained from Sigma (St. Louis, MO, USA). All organic solvents were from Merck (Darmstadt, Germany) and contained butylated hydroxy toluene (50 $\mathrm{mg} / \mathrm{L}$, Sigma) as an antioxidant. All chemicals used were of the highest grade of purity available.

The following buffers were used: Phosphate buffered saline containing $\mathrm{NaCl}$ $(0.137 \mathrm{M}), \mathrm{KCl}(2.6 \mathrm{mM}), \mathrm{Na}_{2} \mathrm{HPO}_{4}(8.1 \mathrm{mM}), \mathrm{KH}_{2} \mathrm{PO}_{4}(1.15 \mathrm{mM}), \mathrm{pH} 7.4$; Tris buffer containing tris-hydroxymethyl-aminomethane $(50 \mathrm{mM}), \mathrm{pH} 7.5$ (adjusted with $\mathrm{HCl}$ ); Trypsin solution containing $0.125 \%(w / v)$ trypsin in phosphate buffered saline supplemented with EDTA $(0.33 \mathrm{mM})$. The standard culture medium consisted of 20\% human serum in M199/RPM11640 (1:1, v/v) supplemented with L-glutamine $(2 \mathrm{mM})$, gentamicin $(50 \mathrm{mg} / \mathrm{ml}), \mathrm{NaHCO}_{3}(11.9 \mathrm{mM})$ and endothelial cell growth supplement $(100 \mu \mathrm{g}$ protein $/ \mathrm{ml})$, as described before [14].

\section{Endothelial cell culture and modification of the fatty acid composition}

Human umbilical vein endothelial cells were isolated from umbilical cord veins and cultured in standard culture medium containing 20\% human serum (pool of at least 200 healthy donors) as described previously [14]. For modification of the endothelial cell fatty acid composition, the cells were cultured in various fatty acid supplemented media from passage 2 to 4 ( 7 or 8 days). The fatty acid supplemented media were prepared by addition of a particular fatty acid sodium salt $\left(200 \mu \mathrm{M}\right.$, final concentration) to warm $\left(37^{\circ} \mathrm{C}\right)$ human serum prior to the addition to culture medium, as described previously [14]. 


\section{Fatty acid analysis}

Monolayers of fatty acid modified endothelial cells were washed twice with cold phosphate buffered saline $\left(4^{\circ} \mathrm{C}\right)$ containing EDTA $(1.35 \mathrm{mM})$. The cells were trypsinized, washed twice with phosphate buffered saline containing EDTA $(1.35 \mathrm{mM})$ and frozen in the same buffer until use $\left(-20^{\circ} \mathrm{C}\right)$. For fatty acid analysis, the cells were thawed and lipids were extracted. Phospholipids were separated from the neutral lipids by thin-layer chromatography, aliquots were taken to quantify phosphorus content and the fatty acids of the phospholipid fraction were methylated and analyzed by gas-liquid chromatography as described previously [15]. A known amount of 19:0 was used as internal standard. The unsaturation index of the endothelial phospholipids was calculated by summation of the percentage of each fatty acid in the phospholipid fraction multiplied by the number of double bonds in that fatty acid.

\section{Lipid peroxidation assay}

The sensitivity to lipid peroxidation was estimated in liposomes prepared from endothelial cell phospholipids by measuring conjugated diene formation with UV difference spectroscopy as described before [16]. Briefly, after purification of endothelial cell phospholipids as described above, silica spots containing the phospholipid fractions were scraped and transfered to glass pipettes. Butylated hydroxytoluene was removed first by elution of the silica with petroleum ether/diethyl ether/water $(120: 25: 1.5, \mathrm{v} / \mathrm{v} / \mathrm{v})$ and the phospholipids by elution with chloroform/methanol/water $(50: 50: 10, \mathrm{v} / \mathrm{v} / \mathrm{v})$. To prevent peroxidation further treatments were carried out under nitrogen. Liposomes of these phospholipids ( $70 \mu \mathrm{M}$ final concentration in $50 \mathrm{mM}$ Tris buffer) were prepared by sonication (10 min. under nitrogen while cooling on ice) and peroxidation of the liposomes was initiated by addition of $\mathrm{CuSO}_{4}$ and $\mathrm{H}_{2} \mathrm{O}_{2}(200 \mu \mathrm{M}$ and $2 \mathrm{mM}$ final concentration, respectively) as described before [16]. The formation of conjugated dienes was monitored continuously by UV difference spectroscopy at $205-300 \mathrm{~nm}$. This method was previously shown to correlate well with other methods for measuring lipid peroxidation, such as measurement of the disappearance of polyunsaturated fatty acids by gas-liquid chromatography and the spectroscopic measurement of the formation of lipid hydroperoxides [16].

For measuring the sensitivity to peroxidation of individual fatty acids, the fatty acid compositions of phospholipid liposomes were determined before and after peroxidation for $80 \mathrm{~min}$. as described above. Using these data the disappearance of various polyunsaturated fatty acids was calculated.

\section{Results}

Influence of long-term fatty acid modification on fatty acid distribution and unsaturation indexes of the endothelial cell phospholipids

Previously, we have shown that long-term culture of endothelial cells in various fatty acid modified media resulted in considerable changes in the fatty acid composition of the phospholipids. Large increases of a polyunsaturated fatty acid and its elongation product were balanced by decreases of other polyunsaturated fatty acids. Increases of saturated fatty 
acids were accompanied by increases of the polyunsaturated arachidonic acid $(20: 4(n-6))[14,15]$. As shown in fig. 1, this resulted in a fairly constant distribution pattern of saturated and unsaturated fatty acids in the phospholipids of all but oleic and linoleic acid modified cells. The endothelial cells modified with oleic acid (18:1(n-9)) showed a remarkable increase in monounsaturated fatty acids at the expense of both saturated and polyunsaturated fatty acids in total phospholipids. Cells modified with linoleic acid (18:2(n-6)) showed an increase in polyunsaturated fatty acids. The phospholipid unsaturation indexes (representing the average number of double bonds present in the membrane phospholipids) were altered to some extent by the fatty acid modification of endothelial cells. For example, the unsaturation index was relatively low for phospholipids of oleic acid modified cells and relatively high for that of cells modified with eicosapentaenoic $(20: 5(n-3))$ or docosahexaenoic (22:6 (n-3)) acid (fig. 1).

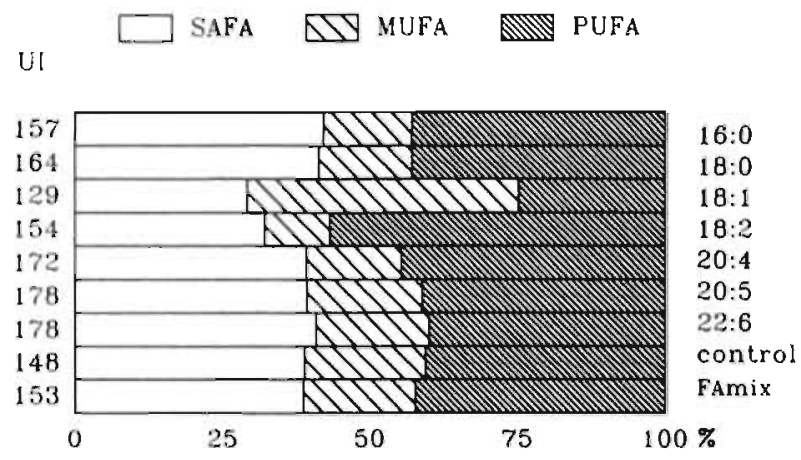

Fig. 1. Unsaturation index and distribution of fatty acid classes in the phospholipids of various fatty acid modified endothelial cells. After long-term culture (7-8 days) of human umbilical vein endothelial cells in standard culture medium supplemented with different fatty acids, phospholipids were extracted and their fatty acid composition determined as described in materials and methods. The unsaturation index (UI) and the total amounts of saturated (SAFA), monounsaturated (MUFA) and polyunsaturated (PUFA) fatty acids, expressed as percentage of total fatty acids, were calculated. Abbreviations: 16:0, 18:0, $18: 1,18: 2,20: 4,20: 5$, and 22:6, indicate phospholipids prepared from endothelial cells modified with palmitic, stearic, oleic, linoleic, arachidonic, eicosapentaenoic, and docosahexaenoic acid, respectively; FAmix, indicates that of additional control cells modified with $200 \mu \mathrm{M}$ of a fatty acid mixture with a highly similar fatty acid composition to that of control cells [19]. Data are mean values of 8-10 independent experiments. SD did not exceed $6 \%$ of mean value.

Sensitivity of individual fatty acids of endothelial cell phospholipids to peroxidation

The extent of peroxidation of individual polyunsaturated fatty acids in phospholipid liposomes prepared from unmodified endothelial cells was 
determined by monitoring the fatty acid decrease with gas-liquid chromatography. The major fatty acid compositions before and after 80 min. peroxidation and the percentage disappearance of various fatty acids are shown in table I. Only polyunsaturated fatty acids were peroxidized. When comparing the loss of fatty acids with the number of double bonds present in each polyunsaturated fatty acid, a direct relationship was found between the sensitivity to lipid peroxidation and the unsaturation degree of individual fatty acids as shown in fig. 2. Also in phospholipids of various fatty acid modified cells the same relationship was found (data not shown). Docosahexaenoic acid was predominantly peroxidized in all fatty acid modified cells.

Table 1. Fatty acid composition of phospholipid liposomes before and after peroxidation.

\begin{tabular}{lccccc}
\hline & & \multicolumn{4}{c}{ FA composition (nmol/nmol PL) } \\
\cline { 3 - 6 } Major FAa & \%FAb & unperoxidized & 80 min peroxidized & FA loss & \% FA lossc \\
\hline $16: 0$ & 20.8 & 0.466 & 0.470 & $\cdots--$ & $\cdots$ \\
$18: 0$ & 13.8 & 0.270 & 0.274 & $\cdots$ & $\cdots$ \\
$18: 1(n-9)$ & 17.4 & 0.322 & 0.325 & --- & -- \\
$18: 2(n-6)$ & 14.5 & 0.282 & 0.202 & 0.080 & 28.4 \\
$20: 3(n-6)$ & 2.0 & 0.038 & 0.020 & 0.018 & 47.4 \\
$20: 4(n-6)$ & 10.7 & 0.193 & 0.064 & 0.129 & 66.8 \\
$22: 4(n-6)$ & 3.0 & 0.050 & 0.019 & 0.031 & 62.0 \\
$20: 5(n-3)$ & 0.6 & 0.010 & 0.003 & 0.007 & 70.0 \\
$20: 5(n-3)$ & 2.5 & 0.033 & 0.008 & 0.025 & 75.8 \\
$22: 6(n-3)$ & 3.3 & 0.051 & 0.008 & 0.043 & 84.3 \\
\hline
\end{tabular}

Phospholipid liposomes were prepared from unmodified endothelial cells and peroxidized with $\mathrm{CuSO}_{4}$ and $\mathrm{H}_{2} \mathrm{O}_{2}$ for $80 \mathrm{~min}$. as described in materials and methods. Phospholipids were extracted and their fatty acid composition was determined before and after peroxidation. Data are mean values of two experiments. Abbreviations: FA, fatty acid; PL, phospholipid. aOnly the major fatty acids are depicted. bFatty acid composition of unperoxidized phospholipids expressed as percentage of total fatty acids. CLoss of fatty acids expressed as percentage of unperoxidized fatty acid.

Influence of membrane fatty acid composition on the sensitivity to lipid peroxidation of endothelial cell phospholipids

In phospholipid liposomes prepared from various fatty acid modified endothelial cells, lipid peroxidation was determined by measuring the formation of conjugated dienes induced by $\mathrm{CuSO}_{4}$ and $\mathrm{H}_{2} \mathrm{O}_{2}$. Fig. 3 shows the influence of the total amount of oxidizable fatty acids present in the phospholipids of various fatty acid modified cells on lipid peroxidation. The phospholipids of cells modified with oleic acid, having the lowest content of polyunsaturated fatty acids (fig. 1), showed a low extent of 


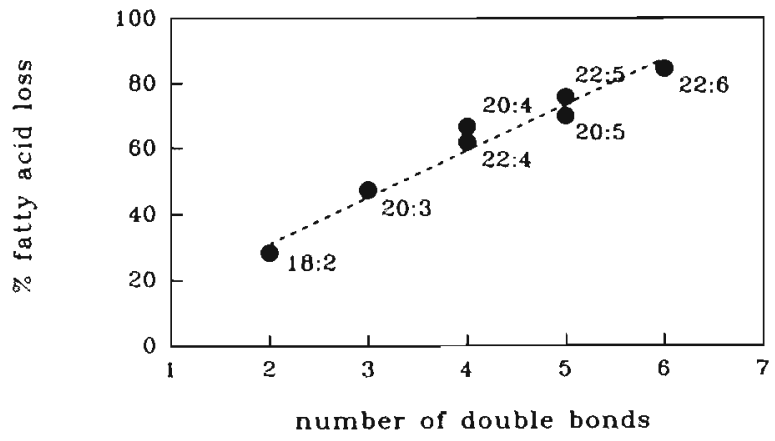

Fig. 2. Disappearance of individual fatty acids from peroxidized phospholipids versus number of double bonds in each fatty acid. Procedure as in table I. Abbreviations: 18:2, $20: 3,20: 4,22: 4,20: 5,22: 5,22: 6$, indicate the polyunsaturated fatty acids expressed as number of carbon atoms : number of double bonds. The values plotted are obtained from table I.

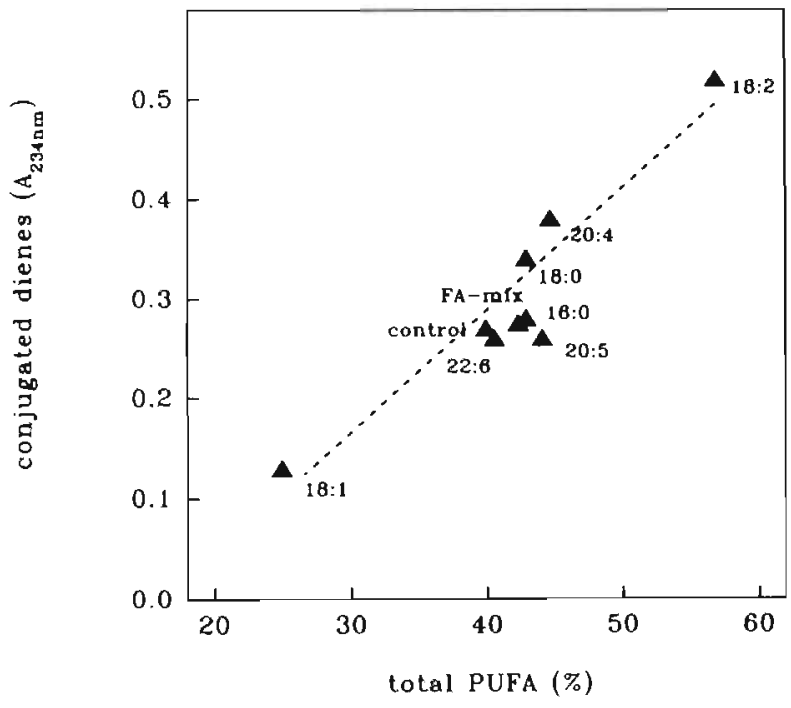

Fig. 3. Conjugated diene formation versus total polyunsaturated fatty acid content of phospholipids for various fatty acid modified endothelial cells. Phospholipids were extracted from different fatty acid modified endothelial cells, liposomes were prepared and peroxidized with $\mathrm{CuSO}_{4}$ and $\mathrm{H}_{2} \mathrm{O}_{2}$ as described in materials and methods. Conjugated diene formation was monitored by UV difference spectroscopy [15], and expressed as the maximal absorption at $234 \mathrm{~nm}$ of peroxidized liposomes against unperoxidized liposomes. Abbreviations and PUFA values from fig. 1. Data are mean values of one experiment in duplicate, representative of 3 so performed. 
lipid peroxidation, while phospholipids of cells modified with linoleic acid (having a high content of polyunsaturated fatty acids) showed a high extent of lipid peroxidation, indicating that an increase of lipid peroxidation was correlated with an increase in polyunsaturated fatty acid content.

Comparison of the maximal amount of conjugated diene formation with the phospholipid unsaturation index of various fatty acid modified endothelial cells, may give an indication of the combined influence of the content of oxidizable fatty acids and their degree of unsaturation on peroxidation of phospholipid liposomes. However, no unequivocal relationship was observed between conjugated diene formation and the unsaturation index. Surprisingly, conjugated diene formation in liposomes of eicosapentaenoic and docosahexaenoic acid modified cells was lower than expected from their unsaturation indexes and their high levels of the best oxidizable fatty acids.

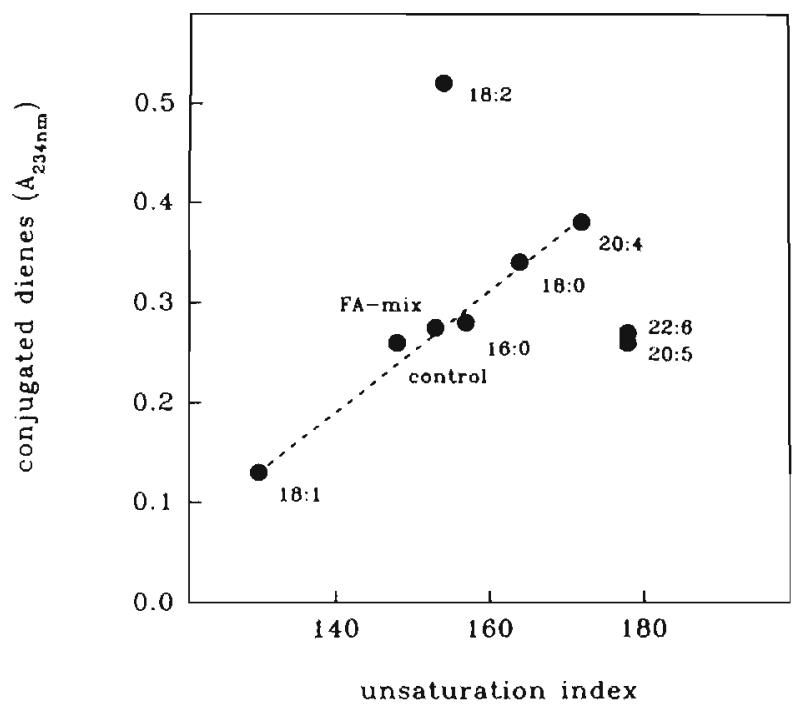

Fig. 4. Conjugated diene formation versus unsaturation index of phospholipids for various fatty acid modified endothelial cells. Procedure as in fig. 3 . Abbreviations as in fig. 1. The values plotted are obtained from fig. 1 and 3.

\section{Discussion}

We have previously demonstrated that in sonicated phosphatidylcholine liposomes the type of oxidizable fatty acid influences the extent of lipid peroxidation initiated by $\mathrm{CuSO}_{4}$ and $\mathrm{H}_{2} \mathrm{O}_{2}$ [16]. In the present study we 
show a differential influence of long-term modification of human endothelial cells with saturated, monounsaturated and n-6 or n-3 polyunsaturated fatty acids on the sensitivity of their phospholipids to peroxidation. Various authors have reported that the extent of lipid peroxidation is influenced by the type of oxidizable fatty acid, the cholesterol content and the phospholipid class composition [16-19]. In our fatty acid modified cells, generally, cholesterol content, phospholipid class composition and average amounts of saturated and polyunsaturated fatty acids in the phospholipids were fairly constant (except for 18:1 and 18:2 modified cells), while the unsaturation indexes of the phospholipids were influenced to some extent by the fatty acid modification [14,15]. This suggests that in the membranes of our modified cells, the type and content of polyunsaturated fatty acids but not the cholesterol content and the phospholipid class composition may play a role in the altered sensitivity to lipid peroxidation. Indeed, the formation of conjugated dienes was found to increase with increasing polyunsaturated fatty acid content of the phospholipids extracted from fatty acid modified endothelial cells. A comparable increase in radiation induced lipid peroxidation with increasing levels of polyunsaturated fatty acids in phospholipid liposomes was reported by Wolters et al. [20]. This suggests that the total amount of oxidizable fatty acids present is a determinant for the sensitivity of a membrane to lipid peroxidation.

Another determinant may be the unsaturation degree of fatty acids. We also studied the influence of the degree of fatty acid unsaturation on the sensitivity of the phospholipids to peroxidation. By measurement of the loss of various types of polyunsaturated fatty acids in the peroxidized phospholipids, we found that the sensitivity to peroxidation of the individual polyunsaturated fatty acids was directly proportional to the number of double bonds present. The ability of individual fatty acids to peroxidation has been reported to be proportional to the concentration of diallyl methylene groups $[19,21]$, which is related to the number of double bonds in polyunsaturated fatty acids and is in agreement with our results. Comparable results were found for radiation induced lipid peroxidation of liposomes prepared from mouse liver [22]. Our results further indicate that docosahexaenoic acid is predominantly peroxidized and linoleic acid least, irrespective of the fatty acid composition of endothelial cells.

Fatty acid modification of endothelial cells, however, changes both the type and content of the polyunsaturated fatty acids. The phospholipid unsaturation index represents the average amount of double bonds present in these phospholipids, which might be available for peroxidation. The unsaturation index thus may be used as a criterion for the combined effect on lipid peroxidation of the total amount of oxidizable fatty acids and the number of double bonds available per fatty acid moiety. The results show, however, no unequivocal relation between the conjugated diene formation 
and the unsaturation index of the phospholipids for all modified cells. A limited relation might be illustrated by phospholipids from cells modified with oleic acid (18:1(n-9)) which showed a low sensitivity and those from arachidonic acid modified cells $(20: 4(n-6))$ which showed a high sensitivity to lipid peroxidation, in line with their respective phospholipid unsaturation indices. This would support the study of Hart et al. [12] who related the effects of supplemented 18:0,18:1 and 18:3 on oxidant injury of endothelial cells to the degree of fatty acid unsaturation. Singh et al. [23] also reported that below a vitamin $\mathrm{E}$ threshold, the content and unsaturation degree of individual fatty acids determine the susceptibility to peroxidation of liver microsomes (measured by thiobarbituric acid reactive substances formation). Surprisingly in our study, however, phospholipids from linoleic acid modified cells showed a relatively high conjugated diene formation and those from eicosapentaenoic and docosahexaenoic acid modified cells showed a relatively low conjugated diene formation compared to their respective unsaturation indices. These data suggest that in addition to the total amount of oxidizable fatty acids and the number of double bonds available, other factors must codetermine the sensitivity to peroxidation of membrane phospholipids. Another determinant could reside in the physico-chemical properties of the lipid bilayer in membranes and liposomes: lipid peroxidation has been described to increase with a decrease in membrane fluidity [24]. This might indicate why phospholipids from docosahexaenoic and eicosapentaenoic acid modified cells display a relatively reduced sensitivity to lipid peroxidation: both these fatty acids may locally increase membrane fluidity [25]. The specific distribution of these polyunsaturated fatty acids in different phospholipid classes [15] might also play a role. The relatively high susceptibility to in vitro lipid peroxidation of linoleic acid containing phosphatidylcholine liposomes observed previously [16] is displayed also by phospholipids from linoleic acid modified endothelial cells. Although the measurement of conjugated diene formation in phospholipid liposomes was previously shown to correlate well with the measurement of loss of polyunsaturated fatty acids [16], it can not be ruled out that differences in timescale of conjugated diene formation between various polyunsaturated fatty acids might interfere.

In conclusion, the results of this study show that long-term fatty acid modification of endothelial cells alters the sensitivity of their membrane phospholipids to lipid peroxidation. In addition, the extent of phospholipid peroxidation is found to correlate with the total content of polyunsaturated fatty acids and with the number of double bonds in an individual fatty acid. However, the relation between membrane unsaturation and sensitivity to peroxidation is not unequivocal. When phospholipid unsaturation indices are taken into consideration, the results suggest that modification of endothelial phospholipids with oleic acid may protect against lipid peroxidation, whereas linoleic acid may act as a promoter. In 
contrast to what might be expected, modification with eicosapentaenoic or docosahexaenoic acid does not increase membrane sensitivity to lipid peroxidation.

\section{Acknowledgements}

The authors want to acknowledge Johan Heemskerk for critically reading the manuscript, the department of Obstetrics and Gynaecology (The Wever Hospital, Heerlen) for supply of umbilical cords and the Red Cross Bloodbank Limburg (Maastricht) for supply of human serum.

\section{References}

1 Halliwell, B., and Gutteridge, J.M.C. 1989. Free radicals, ageing and disease in: Free Radicals in Biology and Medicine, (Halliwell, B., and Gutteridge, J.M.C., eds.), 2nd ed., Oxtord University Press, Oxford, pp. 416-508

2 Bégin, M. 1990. Fatty acids, lipid peroxidation and diseases. Proc. Nutri. Soc. 49, 261-267

3 Ward, P.A. 1991. Mechanisms of endothelial cell killing by $\mathrm{H}_{2} \mathrm{O}_{2}$ or products of activated neutrophils. Am. J. Med. 91, 895-945

4 Ross, A. 1986. The pathogenesis of atherosclerosis - an update. New Eng. J. Med. 314, 488-500

5 Nathan, C.F. 1987. Neutrophil activation on biological surfaces. J. Clin. Invest. 80, 15501560

6 Weiss, S.J., Young, J., LoBuglio, A.F., and Slivka, A. 1981. Role of hydrogen peroxide in neutrophil-mediated destruction of cultured endothelial cells. J. Clin. Invest. 68, 714-721

7 Vercellotti, G.M., Severson, S.P., Duane, P., and Moldow, C.F. 1991. Hydrogen peroxide alters signal Iransduction in human endothelial cells. J. Lab. Clin. Med. 117, 15-24

8 Shasby, D.M., Yorek, M., and Shasby, S.S. 1988. Exogenous oxidants initiate hydrolysis of endothelial cell inositol phospholipids. Blood 72, 491-499

9 Thies, R.L., and Autor, A.P. 1991. Reactive oxygen injury to cultured pulmonary artery endothelial cells: mediation by Poly(ADP-ribose)polymerase activation causing NAD+ depletion and attered energy balance. Arch. Biochem. Biophys. 286, 353-363

10 Geeraerts, M.D., Ronveaux-Dupal, M.F., Lemasters, J.J., and Herman, B. 1991. Cytosolic free $\mathrm{Ca}^{2+}$ and proteolysis in lethal oxidative injury in endothelial cells. Am. J. Physiol. 261, C889-C896

11 Spragg, R.G. 1991. DNA strand break formation following exposure of bovine pulmonary artery and aortic endothelial cells to reactive oxygen products. Am. J. Respir. Cell Mol. Biol. 4, 4-10

12 Hart, C.M., Tolson, J.K., and Block, E. 1991. Supplememal tatty acids atter lipid peroxidation and oxidant injury in endothelial cells. Am. J. Physiol. 260, L481-L488

13 Hart, C.M., Tolson, J.K., and Block, E. 1990. Fatty acid supplementation protects pulmonary artery endothelial cells from oxidant injury. Am. J. Resp. Cell Mol. Biol. 3, 479489

14 Vossen, R.C.R.M., Dam-Mieras, M.C.E. van, Lemmens, P.J.M.R., Hornstra, G., and Zwaal R.F.A. 1991. Membrane falty acid composition and endothelial cell functional properties. Biochim. Biophys. Acta 1083, $243-251$

15 Vossen, R.C.R.M., Feijge, M.A.H., Heemskerk, J.W.M., Dam-Mieras, M.C.E. van, Homstra G., and Zwaal, R.F.A. 1993. Long-term fatty acid modifications of endothelial cells: implications for arachidonic acid distribution in phospholipid classes. J. Lipid Res., in press

16 Vossen, R.C.R.M., van Dam-Mieras, M.C.E., Homstra, G., Zwaal., R.F.A. 1993. Conjugated diene formation as a continuous measurement of lipid peroxidation in an aqueous liposome suspension. Lipids, accepted for publication

17 Mowri, H., Nojima, S., and Inoue, K. 1984. Effect of lipid composition of liposomes on their sensitivity to peroxidation. J. Biochem. 95, 551-558 
18 Montloort, A., Bezstarosti, K., Groh, M.M.J., and Metsá-ketela, T.J.A. 1987. The influence of the lipid composition on the degree of lipid peroxidation of lipsomes. Biochem. Int. 15, 525-543

19 Yamamoto, Y., Niki, E., Kamiya, Y., and Shimasaki, H. 1984. Oxidation of phosphatidylcholines in homogenous solution and in water dispersion. Biochim. Biophys. Acta 795. 332-340

20 Wolters, H., Tilburg, C.A.M. van, Konings, A.W.T. 1987. Radiation-induced lipid peroxidation: influence of oxygen concentration and membrane lipid composition. Int. J. Radiat. Biol., 51, 619-628

21 Gosgrove, J.P., Church, D.F., and Pryor, W.A. 1987. The kinetics of the autoxidation of polyunsaturated fatty acids. Lipids $22,299-304$

22 Mooibroek, J., Trieling, W.B., and Konings, A.W.T. 1982. Comparison of the radiosensitivity of unsaturated fatty acids, structured as micelles or liposomes, under different experimental conditions. Int. J. Radiat. Biol., 42, 601-609

23 Singh, Y., Hall, G.L., Miller, M.G. 1992. Species differences in membrane susceptibility to lipid peroxidation. J. Biochem. Toxicol. 7, 97-105

24 McLean, L.R., and Hagaman, K.A. 1992. Effect of lipid physical state on the rate of peroxidation of liposomes. Free Rad. Biol. Med. 12, 113-119

25 Stubbs, C.D. and Smith, A.D. 1984. The modification of mammalian membrane polyunsaturated fatty acid composition in relation to membrane fluidity and function. Biochim. Biophys. Acta 779, 89 - 137. 

Chapter 7

\section{Effects of Endothelial Cell Fatty Acid Composition on Hydrogen Peroxide Induced Cellular Injury}

Renée C.R.M. Vossen, Maria C.E. van Dam-Mieras, Gerard Hornstra, Robert F.A. Zwaal. 


\begin{abstract}
We studied the influence of membrane fatty acid composition on oxidative injury of endothelial cells. Endothelial cells, of which the membrane fatty acids were modified by long-term culture in media supplemented with a saturated, monounsaturated, or polyunsaturated fatty acid, were incubated with hydrogen peroxide for $30 \mathrm{~min}$. The susceptibility to oxidative injury of intact endothelial cells was studied by measuring DNA strandbreaks as an index for early sublethal cellular injury and ${ }^{51} \mathrm{Cr}$ release as an index for late lethal injury. No influence of fatty acid composition on sublethal or lethal endothelial cell injury was found and no lipid peroxidation was detected in intact cells after short-term $\mathrm{H}_{2} \mathrm{O}_{2}$ treatment. This suggests that under the experimental conditions used, endothelial cell DNA damage is an early oxidative event independent of lipid peroxidation and fatty acid modification. These results support and extend our previous observations illustrating 'homeostasis' at the level of normal endothelial cell functional activity, notwithstanding considerable changes in fatty acid composition.
\end{abstract}




\section{Introduction}

Oxidative stress can induce major derailment of cell metabolism, including DNA damage, damage to specific membrane proteins and lipid peroxidation [1,2]. Lipid peroxidation of endothelial cells and low density lipoproteins probably constitutes a link between oxidative stress and the formation of atherosclerotic lesions [2]. Activated human neutrophils can induce cellular injury and death of endothelial cells by generating cytotoxic quantities of $\mathrm{H}_{2} \mathrm{O}_{2}[3,4]$. As endothelial cell membranes contain relatively large amounts of polyunsaturated fatty acids, lipid peroxidation may contribute to cellular injury and death. Some products of lipid peroxidation such as 4-hydroxynonenal were reported to have cytotoxic effects [5]. One of the earliest events of cell injury during oxidative stress is DNA strand breaking, which can be induced by $\mathrm{H}_{2} \mathrm{O}_{2}$ and lipid peroxidation products [6]. A relatively late event of cell injury is cell leakage $\left({ }^{51} \mathrm{Cr}\right.$ release). However, the relative importance of damage to different molecular targets (DNA, lipids, proteins) in producing cell injury depends on the degree, the mechanism and the time of exposure to oxidative stress [1].

We were interested to know if the fatty acid composition of the endothelial cell phospholipids may influence the extent of DNA damage and oxidative cell injury. We therefore modified the fatty acid composition of endothelial cell membranes in vitro $[7,8]$ and studied DNA strandbreak formation and ${ }^{51} \mathrm{Cr}$ release as induced by short-term $\mathrm{H}_{2} \mathrm{O}_{2}$ treatment. No influence of membrane fatty acid composition on $\mathrm{H}_{2} \mathrm{O}_{2}$ induced sublethal or lethal endothelial cell injury was found. This suggests that DNA strand breaking occurs as an early oxidative event independent of lipid peroxidation and fatty acid modification.

\section{Materials and Methods}

Culture media M199 and RPMI1640 (with L-glutamine and $20 \mathrm{mM}$ HEPES) and $2.5 \%(w / v)$ trypsin solution were obtained from Flow Lab (Bioggio, Switzerland). Tissue culture dishes $\left(60 \mathrm{~cm}^{2}\right.$ (F3003)) were from Falcon (Etten Leur, The Netherlands). EDTA, HEPES and L-glutamine were obtained from Serva (Heidelberg, Germany). Free fatty acids and their sodium salts were obtained from Sigma (St. Louis, MO, USA). ${ }^{51} \mathrm{Cr}$ sodium chromate $(24,2 \mathrm{mCi} / \mathrm{ml}$, $103 \mu \mathrm{g} \mathrm{Cr} / \mathrm{ml}$ ) was purchased from Amersham (Houten, The Netherlands). All chemicals used were of the highest grade of purity available.

The following buffers were used: phosphate buffered saline containing $\mathrm{NaCl}$ (0.137 M), KCl (2.6 mM), $\mathrm{Na}_{2} \mathrm{HPO}_{4}(8.1 \mathrm{mM}), \mathrm{KH}_{2} \mathrm{PO}_{4}$ (1.15 mM), pH 7.4; Hank's buffer containing $\mathrm{NaCl}(0.137 \mathrm{M}), \mathrm{KCl}(6.8 \mathrm{mM}), \mathrm{CaCl}_{2} .2 \mathrm{H}_{2} \mathrm{O}(1.3 \mathrm{mM})$, $\mathrm{MgSO}_{4} .7 \mathrm{H}_{2} \mathrm{O}(0.8 \mathrm{mM}), \mathrm{Na}_{2} \mathrm{HPO}_{4} .2 \mathrm{H}_{2} \mathrm{O}(0.45 \mathrm{mM}), \mathrm{KH}_{2} \mathrm{PO}_{4}(0.45 \mathrm{mM})$, HEPES 
$(10 \mathrm{mM})$, pH 7.2; Trypsin solution contained $0.125 \%(\mathrm{w} / \mathrm{v})$ trypsin in phosphate buffered saline containing EDTA $(0.33 \mathrm{mM})$. The standard culture medium consisted of $20 \%$ human serum in M199/RPMI 1640 (1:1, v/v) supplemented with L-glutamine $(2 \mathrm{mM})$, gentamicin $(50 \mathrm{mg} / \mathrm{ml}), \mathrm{NaHCO}_{3}(11.9 \mathrm{mM})$ and endothelial cell growth supplement $(100 \mu \mathrm{g}$ protein $/ \mathrm{ml})$ as described before [7].

\section{Endothelial cell culture and modification of the fatty acid composition}

Human umbilical vein endothelial cells were isolated from umbilical cord veins and cultured in standard culture medium containing $20 \%$ human serum (pool of at least 200 healthy donors) as described previously [7]. For modification of the endothelial cell fatty acid composition, the cells were cultured in various fatty acid supplemented media from passage 2 to 4 ( 7 or 8 days). The fatty acids (200 $\mu \mathrm{M}$, final concentration) were added as their sodium salt to warm $\left(37^{\circ} \mathrm{C}\right)$ human serum prior to the addition of culture medium as described previously [7].

\section{Measurement of DNA strand breaks}

Early cellular injury of intact endothelial cells was measured in various fatty acid modified cells after treatment with $\mathrm{H}_{2} \mathrm{O}_{2}$ by the fluorescence method described by Bimboim et al. [9] and modified for endothelial cells by Lorenzi et al. [10]. The assay monitors the unwinding of DNA exposed to alkali by measuring the fluorescence due to binding of ethidium bromide to residual double-stranded DNA. The amount of double stranded DNA remaining after alkaline denaturation is inversely proportional to the amount of single strand breaks. Briefly, monolayers of various fatty acid modified endothelial cells at passage 4 were washed twice with Hank's buffer and were incubated with $\mathrm{H}_{2} \mathrm{O}_{2}$ $(0,25,50$, and $75 \mu \mathrm{M}$ final concentration in Hank's buffer) for $30 \mathrm{~min}$. at room temperature in the dark. Then, the cells were washed, trypsinised, centrifuged and the pellet was resuspended in cold buffer $\mathrm{B}\left(0^{\circ} \mathrm{C}\right)\left(6^{*} 106 \mathrm{cells} / \mathrm{ml}\right)$. Aliquots of each cell suspension $(200 \mu \mathrm{l})$ were distributed into 4 sets of tubes: in one set ( $T$, total double-stranded DNA) unwinding in alkali was prevented; in the second (B, background) unwinding was maximized by sonication; and in the third and fourth ( $\mathrm{S}$, samples) unwinding in alkali was allowed to occur without manipulations for 15 and $30 \mathrm{~min}$. respectively. At the end of the desired time of incubation in alkali (performed in the dark) cell lysates were neutralized and diluted with $1.5 \mathrm{ml}$ of the fresly prepared dye solution (ethidium bromide 6.7 $\mu \mathrm{g} / \mathrm{ml}$ in $13.3 \mathrm{mM} \mathrm{NaOH}$ ) and fluorescense was measured. The extent to which DNA strand break formation had occured, was expressed as percentage of double-stranded DNA (\%D) remaining after alkali treatment of the cells and was calculated as (S - B )/( T - B ) x 100\%. A decrease of \% D indicates an increase of DNA strand breaks induced by $\mathrm{H}_{2} \mathrm{O}_{2}$ treatment.

\section{${ }^{51}$ Chromium release assay}

Lysis of intact endothelial cells following oxidative stress was determined in various fatty acid modified endothelial cells by measurement of 51Chromium release of pre-labeled cells according to Harlan et al. [11] after treatment with $\mathrm{H}_{2} \mathrm{O}_{2}$. Briefly, endothelial cells were cultured in media supplemented with various fatty acids in 96-well culture dishes, washed twice with RPMI $+0.1 \%$ human serum albumin and incubated with $100 \mu \mathrm{l} 5 \mathrm{ICr}$ sodium chromate in standard culture medium $\left(25 \mu \mathrm{Ci} / \mathrm{ml}\right.$ final concentration) overnight at $37^{\circ} \mathrm{C}$. Then, the cells were washed 4 times and incubated with $\mathrm{H}_{2} \mathrm{O}_{2}(0,10,30,90 \mathrm{mM}$ 
$\mathrm{H}_{2} \mathrm{O}_{2}$ final concentration in RPMI $+0.1 \%$ human albumin) for $30 \mathrm{~min}$. at $37^{\circ} \mathrm{C}$. The supernatants were collected and centrifuged and radioactivity was determined (A). The cell monolayers were trypsinised and radioactivity was determined (B). Spontaneous $51 \mathrm{Cr}$ release determined in RPMI $+0.1 \%$ human albumin $(C)$ was $4-6 \%$ of maximum release $(A+B)$ after 30 min. incubation. Percentage specific chromium release was expressed as $(A-C) /(A+B-C) x$ $100 \%$.

\section{Lipid peroxidation assay}

Lipid peroxidation induced by $\mathrm{H}_{2} \mathrm{O}_{2}$ treatment of intact endothelial cells was measured by monitoring the loss of polyunsaturated fatty acids. Monolayers of endothelial cells, which were modified with various fatty acids, were incubated with $10 \mathrm{mM} \mathrm{H}_{2} \mathrm{O}_{2}$ or Hank's buffer (blanc) for $30 \mathrm{~min}$. Phospholipids were extracted and separated from neutral lipids as described earlier [8] and phosphorus content was quantified. Phospholipids $(500 \mu \mathrm{mol})$ of both peroxidized and unperoxidized cells were methylated and analysed by gaschromatography as described [8]. Disappearance of polyunsaturated fatty acids was calculated by comparison of the fatty acid compositions of both samples.

\section{Results}

Influence of membrane fatty acid composition on cellular damage induced by hydrogen peroxide treatment of intact endothelial cells

Considerable changes in fatty acid composition of endothelial phospholipids were induced by culturing in media supplemented with various fatty acids as was shown before [7]. In order to investigate if the membrane fatty acid composition of endothelial cells is relevant to the early stage of sublethal cellular injury caused by oxidative stress, DNA strand break induction in these fatty acid modified endothelial cells was measured using ethidium bromide fluorescence. Fig.1 shows DNA strand breaking induced by incubation with $\mathrm{H}_{2} \mathrm{O}_{2}(0,25,50,75 \mu \mathrm{M}$ final concentration) for $30 \mathrm{~min}$. at room temperature. It was found that the percentage double-stranded DNA (\%D) decreased with increasing $\mathrm{H}_{2} \mathrm{O}_{2}$ concentration, indicating increasing DNA strand breaks. However, no appreciable differences among the different fatty acid modified cells were found. Treatment of the modified endothelial cells with X-rays (250 and 500 rad) gave similar results (data not shown).

In order to determine late lethal cellular injury, cell lysis of various fatty acid modified endothelial cells induced by $\mathrm{H}_{2} \mathrm{O}_{2}$ treatment was measured by the ${ }^{51} \mathrm{Cr}$ release method. Fig. 2 gives the percentage $51 \mathrm{Cr}$ release induced by incubation with $\mathrm{H}_{2} \mathrm{O}_{2}(0,10,30$, and $90 \mathrm{mM}$ final concentration) for $30 \mathrm{~min}$ at $37^{\circ} \mathrm{C}$. It was found that cellular damage increased with increasing $\mathrm{H}_{2} \mathrm{O}_{2}$ concentrations, but no appreciable differences were seen between endothelial cells modified with different fatty 

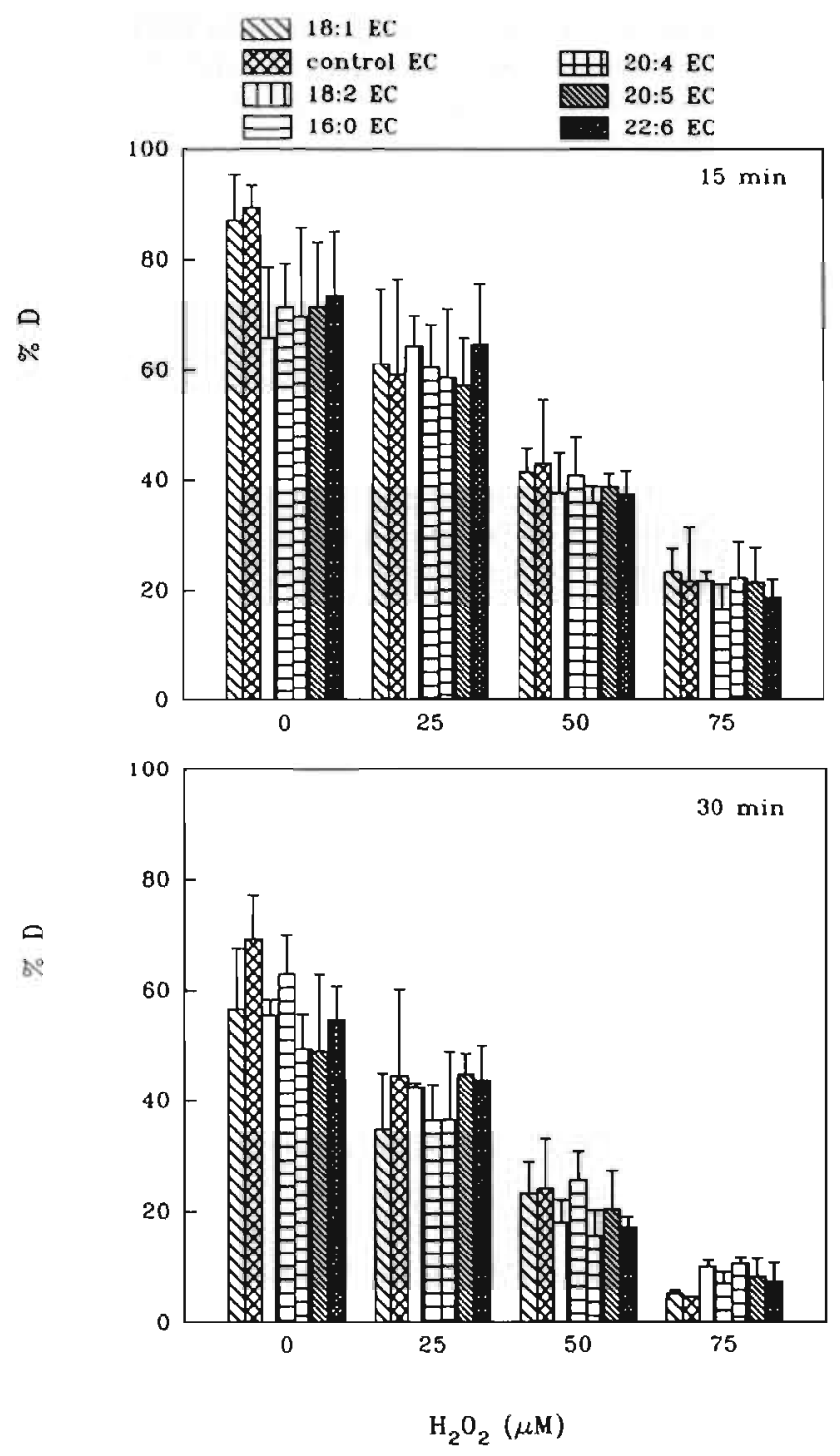

Fig.1. DNA strand break formation of various fatty acid modified endothelial cells induced by $\mathrm{H}_{2} \mathrm{O}_{2}$. Fatty acid modified endothelial cells were incubated for $30 \mathrm{~min}$ with $\mathrm{H}_{2} \mathrm{O}_{2}\left(0,25,50,75 \mu \mathrm{M} \mathrm{H}_{2} \mathrm{O}_{2}\right.$, final concentration), trypsinised and treated mildly with alkali solutions as described in materials and methods. Ethidium bromide fluorescence was measured after alkali treatment at $15^{\circ} \mathrm{C}$ for $15 \mathrm{~min}$. and $30 \mathrm{~min}$. Induction of DNA strand breaks was expressed as percentage double-stranded DNA (\%D), which decreased with increasing DNA damage. Abbreviations: 16:0, 18:1, 20:4, 20:5, indicate endothelial cells cultured with palmitic, oleic, arachidonic,and eicosapentaenoic acid, respectively; C, indicates control cells without modification. Values are mean (SD) of 4 experiments. 
acids. Moreover, relatively high concentrations of $\mathrm{H}_{2} \mathrm{O}_{2}$ were needed to induce cell lysis after $30 \mathrm{~min}$. incubation. At low $\mathrm{H}_{2} \mathrm{O}_{2}$ concentrations, ${ }^{51} \mathrm{Cr}$ release was detected only after long incubation times (more than 6 hours, data not shown). Apparently, endothelial cells are fairly well protected against oxidative damage under the prevailing experimental conditions.

In order to determine if lipid peroxidation took place in intact endothelial cells during the $30 \mathrm{~min} . \mathrm{H}_{2} \mathrm{O}_{2}$ treatment, we also measured the disappearance of polyunsaturated fatty acids under the conditions of maximal DNA damage and minimal chromium release. After incubation of fatty acid modified cells with $10 \mathrm{mM} \mathrm{H}_{2} \mathrm{O}_{2}$ in Hank's buffer for 30 min. at $37^{\circ} \mathrm{C}$, phospholipids were separated and their polyunsaturated fatty acid content was compared with that of buffer treated cells. No decrease in polyunsaturated fatty acids was measured in the $\mathrm{H}_{2} \mathrm{O}_{2}$ treated cells, indicating that no substantial lipid peroxidation occurred during this $30 \mathrm{~min}$. period in which maximal DNA damage was induced (data not shown).

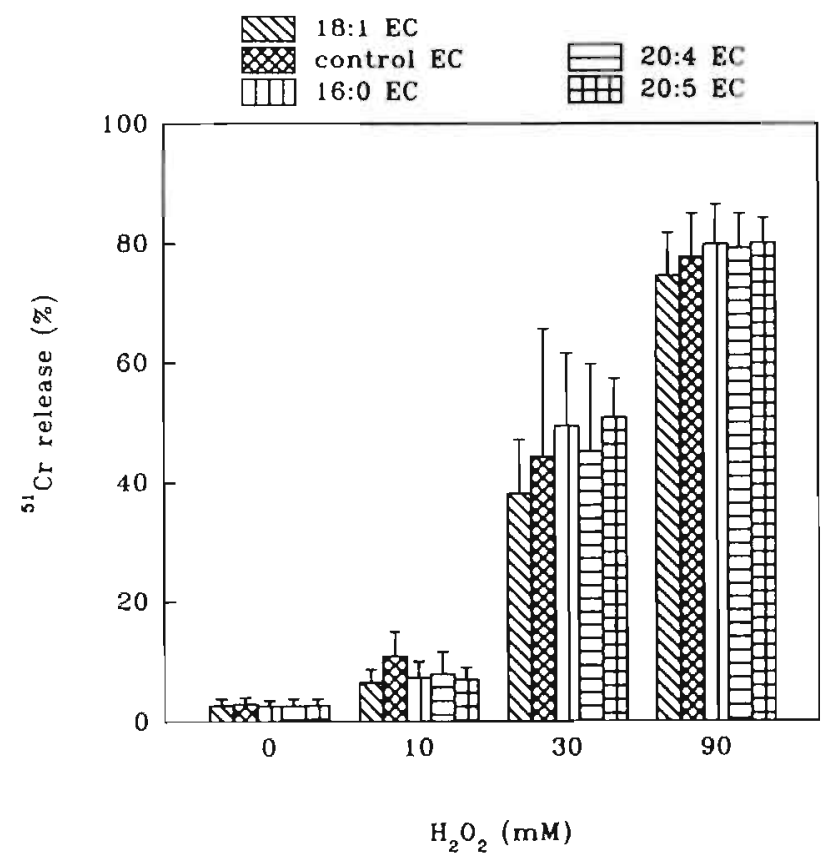

Fig. 2. ${ }^{51} \mathrm{Cr}$ release of various fatty acid modified endothelial cells induced by $\mathrm{H}_{2} \mathrm{O}_{2}$ Pre-labeled fatty acid modified endothelial cells were incubated for $45 \mathrm{~min}$. with $\mathrm{H}_{2} \mathrm{O}_{2}$ $\left(0,10,30,90 \mathrm{mM} \mathrm{H} \mathrm{O}_{2}\right.$ final concentration). $51 \mathrm{Cr}$ release was measured as an indication for lethal cellular injury as described in materials and methods. Abbreviations as in fig. 1 . Values are mean (SD) of 4 experiments. 


\section{Discussion}

We have previously demonstrated that fatty acid modification of human endothelial cells influences the sensitivity to peroxidation of their membrane phospholipids when extracted from the cells [12]. For individual fatty acids the extent of peroxidation is directly proportional to the number of double bonds and in a phospholipid suspension the extent of conjugated diene formation (a measure of the early phase of oxidation) increases with the amount of polyunsaturated fatty acids present. In contrast to what might be expected, however, conjugated diene formation in phospholipids from cells modified with the highly unsaturated eicosapentaenoic or docosahexaenoic acid was remarkably low [12]. It is known that lipid peroxidation products are able to induce DNA strand breaks [6] and that $\mathrm{H}_{2} \mathrm{O}_{2}$ can induce both DNA strand breaks and lipid peroxidation. In order to investigate if the observed differences in peroxidation capacity of membrane phospholipids may lead to different oxidative injury of intact endothelial cells during short-term oxidative stress, we studied the influence of fatty acid modification of endothelial cells on cellular injury induced by $\mathrm{H}_{2} \mathrm{O}_{2}$. The results show that short-term $\mathrm{H}_{2} \mathrm{O}_{2}$ treatment of endothelial cells induces early sublethal DNA strand breaks. This does not seem to be influenced, however, by the membrane fatty acid composition of the cells. In spite of the different capacity to peroxidation of the extracted cellular phospholipids, we could not detect an influence of endothelial fatty acid composition on lipid peroxidation in intact endothelial cells under the experimental conditions used. Apparently, our cells were very well protected against lipid peroxidation in the early phase of oxidative stress. This would also be in agreement with our observation that lethal oxidative injury could only be detected at unphysiologically high $\mathrm{H}_{2} \mathrm{O}_{2}$ concentrations or after long incubation periods. These results are not in agreement with those of Hart et al. [13], who showed that supplementation of saturated and monounsaturated fatty acids reduced oxidant injury in pig pulmonary aortic endothelial cells, while polyunsaturated fatty acids enhanced oxidative injury, measured by lactate dehydrogenase release after short-term $\mathrm{H}_{2} \mathrm{O}_{2}$ treatment. As we cultured endothelial cells for a relatively long time (7-8 days) with supplemented fatty acids, while Hart et al. used a 3 hour incubation [13], it is possible that adaptation of the oxidative defence mechanisms (cellular vitamin $\mathrm{E}$ content, enzyme activities of catalase, superoxide dismutase, glutathione peroxidase, phospholipase $\mathrm{A}_{2}$ ) has occurred during our long-term culture thus preventing lipid peroxidation, while this adaptation may not have occurred under the experimental conditions used by Hart at al. Also, differences in susceptibility to oxidative stress may exist between endothelial cells from different species. In addition, a decrease of intracellular iron content may be induced during in vitro culture of human endothelial cells as was reported by Varani et al. [14]. Sensitivity 
to $\mathrm{H}_{2} \mathrm{O}_{2}$ induced lethal cell injury of human endothelial cells of the first passage was shown to decline rapidly as a function of time in culture (passage 3 and more) together with a fall in iron content and was restored by exogenous iron [14].

Our results suggest that the early sublethal DNA damage induced by the short-term $\mathrm{H}_{2} \mathrm{O}_{2}$ treatment is not mediated by a lipid peroxidation process. As DNA repair mechanisms are very active, poly(ADPribose)polymerase activity may deplete the cells from ATP and NAD+ after long-term $\mathrm{H}_{2} \mathrm{O}_{2}$ treatment, thus inducing lethal cellular injury $[15,16]$, which can be measured by $\mathrm{LDH}$ release or ${ }^{51} \mathrm{Cr}$ release. It is possible that during a longer period of oxidative stress, when endogenous defence mechanisms are exhausted allowing lipid peroxidation to occur, lipid peroxidation products may contribute to cellular injury. This would mean that lipid peroxidation is a rather late oxidative event, possibly accompanying rather than causing final cell death [1]. In that case differences in fatty acid composition could very well affect the extent of cellular damage. Therefore, it would be interesting also to evaluate the cytotoxic effects of specific lipid peroxidation products such as hydroxy alkenals.

In conclusion, DNA damage in our fatty acid modified endothelial cells occurs as an early oxidative event and is not influenced by lipid peroxidation and fatty acid modification. However, our conclusions are drawn from the early phase of the peroxidation process and we can not exclude that the observed variations in susceptibility to peroxidation of extracted phospholipids will influence the extent of cellular injury under pathological conditions of oxidative stress, when also subsequent stages of the process are taken into consideration.

\section{Acknowledgements}

The authors want to thank the department of Obstetrics and Gynaecology (The Wever Hospital, Heerlen) for supply of umbilical cords and the Red Cross Bloodbank Limburg (Maastricht) for supply of human serum.

\section{References}

1 Halliwell, B., Gutteridge, J.M., and Cross, C.E. 1992. Free radicals, antioxidants, and human disease: where are we now? J. Lab. Clin. Med. 119, 598-620

2 Saran, M., and Bors, W. 1990. Radical reactions in vivo - an overvieuw. Rad. Environ. Biophys. 29, 249-262

3 Weiss, S.J., Young, J., LoBuglio, A.F., and Slivka, A. 1981. Role of hydrogen peroxide in neutrophil-mediated destruction of cultured endothelial cells. J. Clin. Invest. 68, 714-721

4 Ward, P.A. 1991. Mechanisms of endothelial cell killing by $\mathrm{H}_{2} \mathrm{O}_{2}$ or products of activated neutrophils. Am. J. Med. 91, 895-945

5 Benedetti, A. , Comporti, M., and Esterbauer, H. 1980. Identification of 4-hydroxynonenal as a cytotoxic product originating from the peroxidation of liver microsomal lipids. Biochim. Biophys. Acta 620, 281-296 
6 Ueda, K., Kobayashi, S., Morita, J., and Komano, T. 1985. Site-specific DNA damage caused by lipid peroxidation products. Biochim. Biophys. Acta 824, 341-348

7 Vossen, R. C. R. M., Dam-Mieras, M. C. E. van, Lemmens, P. J. M. R., Hornstra, G., and Zwaal, R. F. A. 1991. Membrane fatty acid composition and endothelial cell functional properties. Biochim. Biophys. Acta 1083, $243-251$

8 Vossen, R.C.R.M., Feijge, M.A.H., Heemskerk, J.W.M., Dam-Mieras, M.C.E. van, Hornstra, G., and Zwaal, R.F.A. 1993. Long-term fatty acid moditications of endothelial cells: implications for arachidonic acid distribution in phospholipid classes. J. Lipid Res., in press

9 Birnboim, H.C., and Jevcak, J.J. 1981. Fluorometric method for rapid detection of DNA strand breaks in human white blood cells produced by low doses of radiation. Cancer Res. $41,1889-1892$

10 Lorenzi, M., Montisano, D.F. Toledo, S., and Barrieux, A. 1986. High glucose induces DNA damage in cultured human endothelial cells. J. Clin. Invest. 77, 322-325

11 Harlan, J.M., Levine, J.D., Callahan, K.S., and Schwartz, B.R. 1984. Glutathione redox cycle protects cultured endothelial cells against lysis by extracellularly generated hydrogen peroxide. J. Clin. Invest. 73, 706-713

12 Vossen, R.C.R.M., van Dam-Mieras, M.C.E., Hornstra, G., Zwaal., R.F.A. 1993. Differential effects of endothelial cell fatty acid modification on the sensitivity of their membrane phospholipids to peroxidation, submitted for publication

13 Hart, C.M., Tolson, J.K., and Block, E. 1991. Supplemental fatty acids alter lipid peroxidation and oxidant injury in endothelial cells. Am. J. Physiol. 260, L481-L488

14 Varani, J., Dame, M.K., Gibbs, D.F., Tayior, C.G., Weinberg, J.M., Shayevitz, J., and Ward, P.A. 1992. Human umbilical vein endothelial cell killing by activated neutrophils. Loss of sensitivity to injury is accompanied by decreased iron content during in vitro culture and is restored with exogenous iron. Lab. Invest. $66,708-714$

15 Kirkland, J.B. 1991. Lipid peroxidation, protein thiol oxidation and DNA damage in hydrogen peroxide-induced injury to endothelial cells: role of activation of poly(ADPribose)polymerase. Biochim. Biophys. Acta 1092, 319-325

16 Thies, R.L., and Autor, A.P. 1991. Reactive oxygen injury to cultured pulmonary artery endolhelial cells: mediation by Poly(ADP-ribose)polymerase activation causing NAD+ depletion and attered energy balance. Arch. Biochem. Biophys. 286, 353-363 


\section{Chapter 8}

\section{General Discussion}

The present thesis describes an in vitro study of the effects of membrane fatty acid composition on endothelial cell reactivity. Endothelial cells play an important role in atherogenesis and many factors may influence the endothelial cell response to stimulation $[1,2]$. The atherosclerotic plaque is characterized by the presence of deposits of lipid materials, remnants of thrombi, phagocytes and lymphocytes, smooth muscle cells and elements of connective tissue such as collagen, elastin, and glycosaminoglycans. This reflects local activation of the vascular wall by inflammatory stimuli in a chronical process [2]. Ross [1] postulated that the onset of atherogenesis is accompanied with subtle forms of endothelial injury sufficient to stimulate the secretion of growth factors, which lead to smooth muscle cell proliferation. Furthermore, activated monocytes adhere to the endothelium and after migration to the subendothelial space become macrophages and accumulate lipid to form foam cells. Reactive oxygen species released during the oxidative burst accompanying cell activation might induce local damage and contribute to lipid accumulation [3]. However, the kind as well as the cause of endothelial cell injury is not well defined.

From epidemiological studies (recently reviewed [4]) there is evidence that dietary lipids may influence the risk for atherogenesis. We were interested to explore whether there exists a link between membrane fatty acid composition and endothelial cell reactivity. We, therefore, developed different methods to reproducibly modify the fatty acid composition of cultured human endothelial cells. The most appropriate fatty acid modifying procedure appeared to be long-term culturing of endothelial cells in various fatty acid supplemented media. This allowed us to investigate the effect of fatty acid modification on incorporation, distribution and modification of fatty acids in various phospholipid classes and subclasses, and on a variety of endothelial functional activities, which may be important in atherogenesis. 


\section{The in vitro model for endothelial fatty acid modification}

Since Jaffe et al. [5] published a method to culture endothelial cells in vitro, it is widely used to study these cells under controlled conditions without interfering influences of other cell types present in arteries and veins (fibroblasts, smooth muscle cells). However, when culturing endothelial cells in the presence of serum, their fatty acid composition no longer reflects that of the donor species. Therefore, it was necessary to develop a method to modify the endothelial cell fatty acid composition in vitro in order to study its effects on endothelial cell reactivity. We have chosen to use endothelial cells from human umbilical vein cultured with human serum, because these can be isolated and cultured in sufficient amounts from a human source.

Spector et al. [6] already described changes in fatty acid composition of endothelial cells when incubated with supplemented fatty acids. The amount of a particular fatty acid incorporated into endothelial lipids was determined by the amount and the type of fatty acid supplemented to the culture medium $[7,8]$. We first tried several culturing methods using oleic acid for testing their efficiency for in vitro fatty acid modification. Only slight changes in oleic acid content were induced, when endothelial cells were cultured in the presence of $20 \%$ human serum supplemented with vesicles of dioleoylphosphatidylcholine. However, considerable changes in oleic acid content were observed by culturing endothelial cells in the presence of lipoprotein depleted serum, supplemented with high density lipoprotein and vesicles of dioleoylphosphatidylcholine. The highest increase in oleic acid content was induced in the membranes of endothelial cells cultured in the presence of $20 \%$ human serum supplemented with $200 \mu \mathrm{M}$ oleate. The cells showed normal morphological appearance, von Willebrand factor staining and growth rate when cultured in the different experimental media (chapter 2).

Evaluation of the different methods for fatty acid modification showed that culturing endothelial cells with fatty acid modified phosphatidylcholine vesicles probably resulted in degradation of the vesicles in the presence of serum without modification of the cells. Better results were obtained with high density lipoprotein, which was incubated with dioleoylphosphatidylcholine vesicles before addition to the culture medium. Probably, the high density lipoproteins catalysed exchange or uptake of phospholipids from the vesicles and, by subsequent interaction with endothelial cells, modified their fatty acid composition. This method may be very interesting for studying interactions of lipoproteins and endothelial cells. The most appropriate fatty acid modifying method was found to be long-term culturing of endothelial cells in the presence of human serum supplemented with $200 \mu \mathrm{M}$ of a saturated, monounsaturated or polyunsaturated fatty acid. This method differs from that described earlier by others $[6,7]$ in that the endothelial cells were not only incubated 
with the fatty acid modified media (as in the experiments of Spector) but also trypsinized and subcultured in these media for 7 days, allowing normal growth characteristics and equilibrium distribution of the supplemented fatty acid into the endothelial lipid classes and subclasses (chapter 2).

By using this model for long-term fatty acid modification, considerable changes in endothelial cell fatty acid composition were induced. Upon culturing endothelial cells in media supplemented with a particular fatty acid, not only the levels of this fatty acid but also of its elongated product were increased in every phospholipid class, as was reported by others $[6,7,9,10]$. In addition, the $C_{22}$ carbon elongated products were preferentially esterified into PS and EP. Moreover, an increase of a particular fatty acid was always balanced by a change in the level of other fatty acids: for cells modified with a polyunsaturated fatty acid, an increase in this fatty acid was balanced by decreases in other polyunsaturated fatty acids in each phospholipid class. Surprisingly, for cells modified with a saturated fatty acid, an increase in a saturated fatty acid was accompanied by an increase in 20:4(n-6) in every phospholipid class (except SM). This result is in contrast to observations by others $[6,7,9,10]$, who did not find such a 20:4(n-6) increase. However, these authors used relatively short incubations with fatty acids and the difference may be a consequence of our method for long-term fatty acid modification (chapter 3 ).

Long-term fatty acid modification did not produce appreciable changes in cellular protein, cholesterol and phospholipid contents. The endothelial cells showed normal viability and proliferation. Also the phospholipid class content and distribution hardly changed. The average levels of saturated, monounsaturated and polyunsaturated fatty acids in the phospholipid classes of modified endothelial cells remained fairly constant, except for cells modified with oleic acid, which showed an increase in monounsaturated fatty acids at the expense of both saturated and polyunsaturated fatty acids. Cells modified with linoleic acid showed an increase in polyunsaturated fatty acids only in the choline phospholipid class. These results suggest that during long-term fatty acid modification, endothelial cells are able to regulate their membrane characteristics in a 'homeostatic' way. However, such a control of phospholipid unsaturation was not found by others $[6,7,9,10]$, who observed an increase in total polyunsaturated fatty acid content in endothelial cell phospholipids when incubated with a polyunsaturated fatty acid. This presumably reflects an incorporation of fatty acids without reaching equilibrium conditions during the relatively short-term fatty acid modification. Our results also indicate that all fatty acid modified cells seem to economically control their 20:4(n-6) content by elongation and storage into triglycerides of excess $20: 4(n-6)$ and by carefully maintaining a critical $20: 4(n-6)$ level in PI when 20:4(n-6) was limited, irrespective of adaptation to different fatty acid modified media (chapter 3 ). 
To summarize, we have shown that in cultured human endothelial cells extensive variations in fatty acid content can be induced in all phospholipid classes. Changes in one specific fatty acid are counter balanced by adaptational changes in the levels of others in a way suggestive of control of membrane physico-chemistry. The actual physico-chemical properties of the membrane, e.g. membrane fluidity, have not been measured directly in our study, but might yield valuable information in further studies.

The changes in fatty acid composition as induced by our method of fatty acid modification were more extensive than could be attained by dietary means. Moreover, we introduced a relatively long fatty acid modification period into our model. The importance of long-term culture with supplemented fatty acids is shown not only by our results on fatty acid redistribution over phospholipid classes in time (chapter 3 ), the 'homeostatic' control of membrane unsaturation (chapter 3 ) and the compensatory increase of 20:4(n-6) in cells modified with a saturated fatty acid (chapter 2), but also by the results of Rosenthal et al. on the time course of fatty acid elongation [11].

This amplified and long-term fatty acid modification of endothelial cell membranes allowed us to look for possible small effects on cell reactivity. It should be kept in mind, however, that in atherogenesis relatively small alterations of endothelial reactivity persisting for a relatively long period of time, could very well contribute to the final outcome of the process.

\section{Effects of fatty acid modification on endothelial cell reactivity}

We have studied the effect of membrane fatty acid modification on a variety of endothelial functional activities, that might be of importance in atherogenesis [12]. These membrane related functional activities of endothelial cells include a variety of processes [12-17] such as adherence of polymorphonuclear leukocytes and monocytes, endothelial cell procoagulant activity, shedding of procoagulant microvesicles, secretion of von Willebrand factor, production of eicosanoids, sensitivity of the membrane to lipid peroxidation and endothelial cell susceptibility to oxidative stress. The role fatty acids play in these endothelial cell functional activities [18] can at least be considered twofold. On the one hand fatty acids, as part of phospholipids in biomembranes, contribute to creating a suitable microenvironment for membrane-associated processes. On the other hand fatty acids can actively participate in such processes by being used as a substrate or target molecule during cell activation.

Evaluation of the results indicates that in those cases in which fatty acids contribute to creating a microenvironment for membrane-associated 
processes, but do not actively participate in these processes, fatty acid modification has no effect on endothelial cell reactivity. We have found no influence of membrane fatty acid modification on various general inflammatory and hemostatic processes, such as the adherence of polymorphonuclear leukocytes and monocytes to the endothelial monolayer, the ability of an endothelial monolayer to facilitate fibrin clot formation in recalcified human plasma (procoagulant activity) (chapter 2 ), and the shedding of procoagulant microvesicles by complement C5b-9 stimulated endothelial cells, measured as the exposure of a catalytic surface on the membrane for thrombin generation (prothrombinase activity) (chapter 4). This suggests that the exposure of adhesive receptors, the assembly and/or activation of coagulation factors, and the membrane processes required to form procoagulant microvesicles are subject to 'homeostatic' control. Our results indicate that the observed control of membrane fatty acid unsaturation maintains 'homeostasis' at the level of endothelial cell reactivity, allowing normal cell functioning.

Furthermore, the reactivity of endothelial cells to short-term oxidative stress was not affected by their fatty acid composition: neither $\mathrm{H}_{2} \mathrm{O}_{2}$ induced DNA strand breaking in endothelial cells nor cell leakage ( 51 chromium release) were influenced by membrane fatty acid modification (chapter 7). The results suggest that DNA damage occurs as an early event independent of lipid peroxidation.

In those cases in which fatty acids not only provide a suitable microenvironment for membrane-associated processes, but also actively participate in these processes either directly or indirectly, an effect of fatty acid modification on endothelial cell reactivity is found. When membrane fatty acids serve as a substrate pool for the formation of local mediators, we found that eicosanoid production of endothelial cells was influenced by their membrane fatty acid composition, especially with a considerable decrease in $20: 4(\mathrm{n}-6)$ content in cells modified with $20: 5$ (n-3) (chapter 2). This confirms previous observations with relatively short-term fatty acid incubations [6,7]. Another important membraneassociated local mediator induced by thrombin is platelet activating factor. The production of platelet activating factor by endothelial cells was recently reported to be increased after short-term incubation with $\mathrm{C}_{20}$ fatty acids [10]. As we found no influence of fatty acid modification on leukocyte adherence, which is mediated also by platelet activating factor, it would be of interest to study the production of platelet activating factor in our long-term fatty acid modified cells.

Furthermore, since polyunsaturated fatty acids in the membrane are substrate for peroxidation during oxidative stress, the sensitivity to peroxidation of the isolated endothelial cell phospholipids was affected by their fatty acid composition (chapter 6 ). The sensitivity to peroxidation of individual polyunsaturated fatty acids in phospholipid liposomes was found to be proportional to the number of double bonds per fatty acid 
moiety. A comparable relation for choline-phospholipids was previously found by Yamamoto et al. [19]. In addition, conjugated diene formation by peroxidation of the phospholipid liposomes prepared from the fatty acid modified endothelial cells, was related to the total amount of polyunsaturated fatty acids, but not unequivocally to the unsaturation index (a measure of the average amount of double bonds in the phospholipids) (chapter 6). Our results suggest that modification of endothelial cells with oleic acid may protect their phospholipids against peroxidation, whereas linoleic acid may promote peroxidation. In contrast to what might be expected, modification with eicosapentaenoic or docosahexaenoic acid did not increase the extent of membrane phospholipid peroxidation. It remains to be investigated, however, whether these differences in sensitivity to peroxidation of membrane phospholipids may lead to different susceptibilities to oxidative injury of intact endothelial cells. The results of Block et al. [20] suggest such a relation for porcine pulmonary artery endothelail cells, although these cells seem to be much more sensitive to oxidative stress than the human cells used in our study. As the endogenous antioxidant defense mechanisms play an important role in the sensitivity of cells to oxidative injury [17], future research should focus on this as well as on the endogenous production of free radicals by endothelial cells. Furthermore, as lipid peroxidation contributes to cell damage [3], the cytotoxic effects of lipid peroxidation products should also be evaluated.

Certain fatty acids may also participate indirectly in membraneassociated processes. This could be inferred from observations on the stimulated release of von Willebrand factor from the endothelial storage granules, as membrane fatty acid modification specifically affected this endothelial cell functional activity. We have shown a specific increase of PMA or thrombin induced secretion of von Willebrand factor from endothelial cells modified with 20:4(n-6) (chapter 4). Since at present the influence of $20: 4(n-6)$ on protein kinase $C$ activity and/or eicosanoid synthesis can not be ruled out $[21,22]$, the actual mechanism and significance of this phenomenon remains to be explored.

\section{Conclusion}

We have shown that extensive modifications of fatty acid composition can be induced in endothelial cell phospholipids in vitro, without influencing cell viability and growth. The overall effect of fatty acid modification on endothelial cell reactivity is limited by 'homeostatic' control of membrane physico-chemical properties, allowing normal endothelial cell functioning. However, in those cases in which fatty acids 
are reactive participants in cellular activation phenomena, an effect on cell reactivity is found.

The role that fatty acids play in altering endothelial cell reactivity appears to be relatively small. The cells seem to be able to control their initial response to stimulation (PI mediated), notwithstanding extensive alterations in fatty acid composition. However, further amplification of the activation response (e.g. phospholipase $\mathrm{A}_{2}$ and protein kinase $\mathrm{C}$ mediated) seems to be influenced by alterations in fatty acid content. During chronical stimulation, the alterations in endothelial cell reactivity may become more evident. It should be emphasized, however, that these conclusions are drawn from experiments with cultured cells displaying fatty acid changes that most probably are larger than those reached by dietary manipulation in vivo. This is especially true for the rise in 20:4 (n-6) content in 20:4 modified endothelial cells. When we try to extrapolate these results to the endothelial cell in vivo, a situation in which less dramatic fatty acid alterations are induced by dietary means, it can be hypothesized that, although membrane physico-chemistry is under 'homeostatic' control, fatty acid modifications may influence endothelial cell reactivity when fatty acids actively participate in the stimulatory processes. Such relatively small alterations in endothelial reactivity upon stimulation, when persisting for a relatively long period of time, could influence the formation of atherosclerotic lesions. Fatty acids can be considered to some extent as modifiers of the response after stimulation by a broad spectrum of initial stimuli, which can range from mechanical injury via inflammation to immunological stimulation.

This study is performed with endothelial cells derived from umbilical veins. Keeping in mind that atherosclerosis is a chronic process the arteries, the effects of fatty acid modification on endothelial reactivity remain to be studied also in endothelial cells cultured from human arteries. Furthermore, the role of oxidized low density lipoproteins in atherogenesis [23] and the possible influence of fatty acid composition and endothelial cell reactivity on their peroxidation should be taken into account. We therefore would like to suggest that our in vitro model may be useful in studying the effect of fatty acid modification on intercellular communication and on the interaction between arterial endothelial cells and lipoproteins.

\section{References}

1 Ross, R. 1986. The pathogenesis of atherosclerosis - and update. N. Engl. J. med. 314, 488-500

2 Bruggeman, C., and van Dam-Mieras, M.C.E. 1991. The possible role of cytomegabovirus in atherogenesis. in: Prog. Med. Virol. (Melnick, J.L., ed) V38, Karger, Basel, pp. 1-26 
3 Halliwell, B., and Gutteridge, J.M.C. 1989. Free radicals, ageing and disease in: Free Radicals in Biology and Medicine, (Halliwell, B., and Gutteridge, J.M.C., eds.), 2nd ed., Oxtord University Press, Oxtord, pp. 416-508

4 Ulbricht, T.L.V., and Southgate, D.A.T. 1991. Coronary heart disease: seven dietary factors. The Lancet, 338, 985-992

5 Jaffe, E.A., Nachman, R.L., Becker, C.G., Minick, C.R. 1973. Culture of human endothelial cells derived Irom umbilical veins: indentification by morphologic and immunologic criteria. J. Clin. Invest. 52, 2745-2756

6 Spector, A.A., Hoak, J.C., Fry, G.L., Denning, G.M., Stoll, L.L., and Smith J.B. 1980. Effect of fatty acid modification on prostacyclin production by culturod human endothelial cells. $\mathrm{J}$. Clin. Invest. 65, 1003-1012

7 Spector, A.A., Yorek, M.A. 1985. Membrane lipid composition and cellular function. J. Lipid Res. 26, 1015-1035

8 Stubbs, C.D., Smith, A.D. 1984. The modification of mammalian membrane polyunsaturated fatty acid composition in relation to membrane fluidity and function. Biochim. Biophys. Acta $779,89-137$

9 Henning, B., and Watkins, B.A. 1988. Linoleic acid and linolenic acid: effect on permeability properties of cultured endothelial cell monolayers. Am. J. Clin. Nutr. 49, 301-305

10 Garcia, M.C., Mueller H.W., and Rosenthal, M.D. 1991. C20 polyunsaturated fatty acids and phorbol myristate acetale enhance agonist-stimulated synthesis of 1-radyl-2-acelyl-snglycero-3-phosphocholine in vascular endothelial cells. Biochim. Biophys. Acta 1083, 3745

11 Rosenthal, M.D., Garcia, M.C., Jones, M.R., and Sprecher, H. 1991. Retroconversion and $\Delta^{4}$ desaturation of docosatetraenoate $(22: 4(n-6))$ and docosapentaenoate $(22: 5(n-3))$ by human cells in culture. Biochim. Biophys. Acta 1083, $29-36$

12 DiCorle10, P.E., and Chisolm, G.M. 1986. Participation of the endothelium in the development of the atherosclerotic plaque. Prog. Lipid Res. 25, 365-374

13 Rodgers, G.M. 1988. Hemostatic properties of nomal and perturbed vascular cells. FASEB J. 2, 116-1234

16 Ward, P.A. 1991. Mechanisms of endothelial cell killing by $\mathrm{H}_{2} \mathrm{O}_{2}$ or products of activated neutrophils. Am. J. Med. 91, 89S-94S

15 Morgan, B.P. 1989. Complement membrane attack on nucleated cells: resistance, recovery and non-lethal effects. Biochem. J. 264, 1-14

16 Smith, W.L. 1989. The eicosanoids and their biochemical mechanism of action. Biochem. J. 259, 315.324

17 Halliwell, B., Gutteridge, J.M., and Cross, C.E. 1992. Free radicals, antioxidants, and human disease: where are we now? J. Lab. Clin. Med. 119, 598-620

18 Memill, A.H. 1989. Lipid modulators of cell function. Nutr. Rev. 47, 161-169

19 Yamamolo, Y., Niki, E., Kamiya, Y., and Shimasaki, H. 1984. Oxidation of phosphatidylcholines in homogenous solution and in water dispersion. Biochim. Biophys. Acta 795, 332-340

20 Hart, C.M., Tolson, J.K., and Block, E. 1991. Supplemental fatty acids atter hipid peroxidation and oxidant injury in endothelial cells. Am. J. Physiol. 260, L481-L488

21 Whatley, R.E., Zimmerman, G.A., Mcintyre, T.M., and Prescott, S.M. 1990. Lipid metabolism and signal transduction in endothelial cells. Prog. Lipid Res. 29, 45-63

22 Lelkes, P.I., and Pollard H.B. 1991. Cytoplasmic determinants of exocytotic membrane fusion. in: Membrane fusion (Wilschut, J. and Hoekstra, D., eds.) Marcel Dekker Inc, New York, pp. 511-551

23 Parthasarathy, S., Steinberg, D., and Witztum, J.L. 1992. The role of oxidized low density lipoproteins in the pathogenesis of atherosclerosis. Annu. Rev. Med. 43, 219-225 


\section{Summary}

This thesis describes an in vitro study of the effects of fatty acid modification on endothelial cell reactivity. Both dietary lipids and endothelial cells are recognised to play a role in atherogenesis. The development of atherosclerosis is considered to be a multifactorial process in which, among others, a derailment of normal inflammatory and hemostatic processes, occurring as a response to activation of the arterial wall, are involved. Endothelial cells, because of their characteristic localisation at the interface between circulatory system and tissues may play a crucial role in those processes. A broad range of stimuli may cause endothelial cell activation, which among others results in an increase in leukocyte adherence and transport of cells across the vascular wall (chapter 1). It will be evident that any modification that influences normal endothelial cell reactivity might contribute to these phenomena. In this respect, we were interested to explore whether there exists a link between membrane fatty acid composition and endothelial cell reactivity. We, therefore, developed a model to reproducibly modify the fatty acid composition of cultured human endothelial cells in order to study its effect on a variety of endothelial functional activities, which may be important in atherogenesis.

In chapter 2 different methods to modify the fatty acid composition in vitro were developed. Endothelial cells (from human umbilical cord) were cultured for about 7 days in media containing either high density lipoprotein and dioleoyl phosphatidylcholine vesicles, or human serum and sodium oleate. Evaluation of the different protocols showed that the most appropriate method was long-term culturing of endothelial cells in the presence of human serum supplemented with $200 \mu \mathrm{M}$ of a saturated, monounsaturated or polyunsaturated fatty acid. In chapter 3 we further investigated this fatty acid modification procedure at the level of the individual phospholipid classes. In contrast to the commonly used shortterm fatty acid incubations, our long-term fatty acid modification resulted in an increase of the supplemented fatty acid (and elongation products) in each phospholipid class, which was always counter balanced by adaptational changes in the levels of other fatty acids in a way suggestive of control of membrane unsaturation. We have found that long-term modification of endothelial cells with a saturated fatty acid was accompanied by an increase of arachidonic acid $(20: 4(n-6))$ in the membrane phospholipids.

Because of the role of 20:4(n-6) in cellular communication as a substrate for bioactive mediators, the influence of endothelial cell fatty 
acid modification on the incorporation, distribution and modification of 20:4(n-6) in each phospholipid class, was also studied using radiolabeled arachidonic acid (chapter 3 ). Our results indicated that all fatty acid modified cells appeared to economically control their 20:4(n-6) content by storing excess of $20: 4(n-6)$ into triglycerides and elongation. Moreover, a critical 20:4(n-6) level was carefully maintained in phosphatidylinositol when $20: 4(n-6)$ content was limited, irrespective of modifications in the other phospholipid classes.

This method of long-term fatty acid modification enabled us to study the effects of membrane fatty acid composition on several functional activities of endothelial cells. Evaluation of the results indicated that in those cases in which fatty acids contribute to creating a microenvironment for membrane-associated processes, but do not actively participate in these processes, fatty acid modification has no effect on endothelial cell reactivity. Thus, we have found no influence of membrane fatty acid modification on various general inflammatory and hemostatic processes, such as the adherence of polymorphonuclear leukocytes and monocytes to the endothelial monolayer, the ability of an endothelial monolayer to facilitate fibrin formation in recalcified human plasma (procoagulant activity) (chapter 2), hydrogen peroxide induced DNA damage (chapter 7), and the shedding of procoagulant microvesicles by complement C5b-9 stimulated endothelial cells, measured as the generation of a catalytic membrane surface that stimulates thrombin formation (prothrombinase activity) (chapter 4). This indicates that the observed control of membrane fatty acid unsaturation maintains 'homeostasis' at the level of endothelial cell reactivity, allowing normal cell functioning.

Conversely, in those cases in which fatty acids not only provide a suitable microenvironment for membrane-associated processes, but also actively participate in these processes either directly or indirectly, an effect of fatty acid modification on endothelial cell reactivity was found. When cell activation requires that membrane fatty acids are used as a substrate molecule for the formation of bioactive mediators, we have found that eicosanoid production by endothelial cells (e.g. following thrombin activation) was influenced by their membrane fatty acid composition, especially when the cells exhibited a considerable decrease in 20:4(n-6) content as a result of modification with 20:5(n-3) supplemented media (chapter 2). Furthermore, in those cases in which membrane fatty acids are target molecules for reactive oxygen intermediates formed during cellular activation, the sensitivity to peroxidation of isolated endothelial cell phospholipids was affected by their fatty acid composition (chapter 6). The sensitivity to peroxidation of an individual polyunsaturated fatty acid in peroxidized phospholipids was found to be proportional to the number of double bonds in that fatty acid. In addition, conjugated diene formation during peroxidation of isolated endothelial cell phospholipids was related to the total amount of 
polyunsaturated fatty acids present. However, no unequivocal relation was found between conjugated diene formation and the unsaturation index (a measure of the average amount of double bonds in the phospholipids) (chapter 6).

An indirect participation of certain fatty acids in membrane-associated processes could be infered from observations on the stimulated release of von Willebrand factor from the endothelial storage granules. We have shown a specific increase of PMA or thrombin induced von Willebrand factor secretion in endothelial cells modified with 20:4(n-6) (chapter 4). Since at present the influence of $20: 4(n-6)$ on protein kinase $C$ activity and/or eicosanoid synthesis can not be ruled out, the actual mechanism and significance of this phenomenon remains to be explored.

In summary, we have shown that relatively large modifications of fatty acid composition can be induced in endothelial cell phospholipids in vitro, without influencing the growth characteristics and viability of the cells. However, the overall effect of long-term fatty acid modification on endothelial cell reactivity appears to be limited by 'homeostatic' control of the membrane physico-chemical environment, allowing normal cell functioning. On the other hand, in those cases in which fatty acids are active participants in cellular activation phenomena, endothelial cell reactivity is affected. 



\section{Samenvatting}

Hart en vaatziekten vormen een van de belangrijkste doodsoorzaken in de ontwikkelde landen. Meestal ligt het proces van atherosclerose (aderverkalking) hieraan ten grondslag. Atherosclerose is een chronische aandoening van de vaatwand in arteriën, waarbij in de loop der jaren plaatselijke verdikkingen van de intima (de binnenwand) ontstaan die kunnen leiden tot vaatvernauwing. De elasticiteit van de arteriën vermindert eveneens. Tijdens de ontwikkeling van een atherosclerotische plaque (vaatwandverdikking) dringen monocyten (witte bloedcellen) vanuit het bloed de vaatwand binnen waar ze veranderen in schuimcellen door grote hoeveelheden vetten (voornamelijk cholesterolesters) op te nemen. Verder migreren gladde spiercellen naar de intima, waardoor de plaque groeit en vaatvernauwing veroorzaakt. Er zijn talrijke aanwijzingen dat voedingsvetten en endotheelcellen hierbij een rol spelen. Bij het proces van atherosclerose zijn vele factoren betrokken. Een factor is het ontsporen van normale ontstekings- en stollingsreacties die optreden tijdens activatie van de vaatwand. De endotheelcellen, die als binnenbekleding van de vaatwand een actieve barrière vormen tussen het bloed en de omringende weefsels, zijn nauw betrokken bij deze processen. Een breed scala aan stimulantia kan de endotheelcellen activeren, hetgeen o.a. kan leiden tot een verhoogde adherentie (hechting) van leukocyten en monocyten en transport van cellen over de vaatwand.

Elke modificatie die de normale reactiviteit van endotheelcellen verandert, kan bovengenoemde processen beïnvloeden. Voedingsvetten die de vetzuursamenstelling van bloedcellen en vaatwandcellen beïnvloeden, zouden hierbij een rol kunnen spelen. In dit verband waren wij geïnteresseerd of er een relatie bestaat tussen de reactiviteit van endotheelcellen en de vetzuursamenstelling van de celmembraan. Aangezien het zeer moeilijk is om endotheelcellen in vivo te bestuderen, werd een in vitro methode ontwikkeld waarmee de vetzuursamenstelling van gekweekte endotheelcellen op reproduceerbare wijze kan worden veranderd. Met behulp van deze methode werden de effecten van vetzuurmodificatie op verschillende functionele activiteiten van endotheelcellen bestudeerd, die van belang kunnen zijn in het atherosclerotisch proces.

Verschillende methoden werden ontwikkeld om de vetzuursamenstelling van endotheelcellen in vitro te modificeren (hoofdstuk 2). Endotheelcellen werden geïsoleerd uit menselijke navelstrengen en ongeveer 7 dagen gekweekt in verschillende vetzuur-gemodificeerde media. De meest geschikte methode was het langdurig kweken van endotheelcellen in aanwezigheid van menselijk serum, waaraan $200 \mu \mathrm{M}$ van een verzadigd, mono-onverzadigd of poly-onverzadigd vetzuur was 
toegevoegd. Deze methode werd verder onderzocht op het nivo van de individuele fosfolipide klassen in de celmembraan (hoofdstuk 3). Vetzuurmodificatie veroorzaakte in iedere fosfolipide klasse een verhoging van het toegevoegde vetzuur (en elongatieprodukten). In tegenstelling tot de vaak gebruikte korte vetzuurincubatie, werd deze verhoging tijdens onze langdurige vetzuurmodificatie telkens gecompenseerd door veranderingen in de concentraties van andere vetzuren in de fosfolipiden, waarbij geen veranderingen plaatsvonden in de fosfolipiden-, cholesterol- en eiwitconcentraties. Een langdurige modificatie van endotheelcellen met een verzadigd vetzuur veroorzaakte niet alleen een verhoging van dat vetzuur, maar ook een verhoging van arachidonzuur (het poly-onverzadigd vetzuur 20:4(n-6)) in de membraanfosfolipiden. Dit alles wijst op een subtiele regulatie van de onverzadigingsgraad van de endotheelcelmembraan, ongeacht grote veranderingen in vetzuursamenstelling.

Tijdens celactivatie wordt door de endotheelcel o.a. uit het arachidonzuur in de membraanfosfolipiden verschillende bioactieve mediatoren (intracellulaire 'communicatie' molekulen) geproduceerd. De invloed van vetzuurmodificatie op de incorporatie, distributie en modificatie van arachidonzuur in iedere fosfolipide klasse werd bestudeerd met behulp van radioactief gemerkt arachidonzuur (hoofdstuk 3). Het bleek dat alle vetzuur-gemodificeerde cellen de hoeveelheid arachidonzuur in de membraanfosfolipiden efficiënt reguleerden, o.a. door 'opslag' van een overmaat aan arachidonzuur in de triglyceriden en door elongatie. Bovendien bleek dat, tijdens kweekcondities met een relatief lage hoeveelheid arachidonzuur, de cellen een critisch arachidonzuumivo handhaafden in fosfatidylinositol, ongeacht de vetzuurveranderingen in de andere fosfolipide klassen.

Vervolgens werden de effecten van langdurige vetzuurmodificatie op verschillende functionele activiteiten van endotheelcellen bestudeerd. De resultaten wijzen er op dat vetzuurmodificatie geen effect heeft op de reactiviteit van endotheelcellen indien vetzuren alleen bijdragen tot de vorming van een geschikte micro-omgeving waarin membraangeassocieerde processen plaatsvinden, maar zelf niet actief deelnemen aan deze processen. Er werden geen effecten van vetzuurmodificatie gevonden op verschillende algemene ontstekings- en stollingsreacties, zoals 1: de hechting van leukocyten en monocyten aan endotheelcellen, 2: de stolactiviteit van endotheelcellen (versnelling van de fibrinevorming in plasma) (hoofdstuk2), 3: de door waterstofperoxide geünduceerde DNA schade (hoofstuk 7), en 4: de afsnoering van stolactieve microvesikels door complement-geactiveerde endotheelcellen (gemeten als prothrombinase activiteit; de inductie van een katalytisch membraanoppervlak dat thrombinevorming stimuleert) (hoofdstuk 4). Dit wijst er op dat de eerder gevonden subtiele regulatie van de onverzadigingsgraad van de membraan in vetzuurgemodificeerde endotheelcellen als het ware een 
'homeostase' handhaaft op het nivo van de endotheelcelreactiviteit, waarbij de cel normaal blijft functioneren.

Een effect van vetzuurmodificatie op de endotheelcelreactiviteit is daarentegen wel gevonden in die gevallen waarin vetzuren, naast een passieve rol bij de vorming van een geschikte micro-omgeving voor membraan-geassocieerde processen, ook zelf aktief deelnemen aan deze processen. Waar bij celactivatie membraanvetzuren worden gebruikt als substraat voor bioactieve mediatoren, bleek dat de produktie van eicosanoïden (intracellulaire 'communicatie' molekulen) in endotheelcellen werd beïnvloed door de vetzuursamenstelling van de membraan. Er werd aangetoond dat de productie van eicosanoïden verlaagd was in cellen met een lage hoeveelheid arachidonzuur in de membraan, als gevolg van modificatie met eicosapentaeenzuur verrijkt medium (het polyonverzadigd visolie-vetzuur 20:5(n-3)) (hoofdstuk 2). Waar membraanvetzuren worden aangevallen en geperoxideerd door (tijdens celactivatie gevormde) reactieve zuurstof intermediairen, bleek dat de gevoeligheid voor peroxidatie van fosfolipiden, die uit endotheelcellen zijn geïsoleerd, werd beïnvloed door de vetzuursamenstelling (hoofdstuk 6). De gevoeligheid voor peroxidatie van een individueel poly-onverzadigd vetzuur bleek evenredig te zijn met het aantal dubbele bindingen in dat vetzuurmolekuul. Tevens werd een relatie gevonden tussen de hoeveelheid geconjugeerde diënen (peroxidatieproducten) en de totale hoeveelheid poly-onverzadigde vetzuren in geïsoleerde endotheelcelfosfolipiden. Er was echter geen eenduidige relatie tussen geconjugeerde diënen en de onverzadigingsindex van deze fosfolipiden (een maat voor het gemiddeld aantal dubbele bindingen in de fosfolipiden) (hoofdstuk 6).

Een indirekte deelname van vetzuren aan membraan-geassocieerde processen zou kunnen worden afgeleid uit de gestimuleerde secretie van von Willebrand Factor uit endotheelcellen. Een specifieke verhoging van de gestimuleerde von Willebrand Factor secretie werd aangetoond in met arachidonzuur gemodificeerde endotheelcellen (hoofdstuk 4). Aangezien de invloed van arachidonzuur op de activiteit van proteïnekinase $C$ en/of de produktie van eicosanoïden niet kan worden uitgesloten, zal het mechanisme en de functie van dit fenomeen verder onderzocht moeten worden.

Samenvattend werd aangetoond dat relatief grote modificaties van de vetzuursamenstelling in gekweekte endotheelcellen kunnen worden geïnduceerd, zonder de groeikarakteristieken en vitaliteit van de cellen te beïnvloeden. Globaal gezien blijft het effect van langdurige vetzuurmodificatie beperkt door een 'homeostatische' regulatie van fysischchemische eigenschappen van de membraan, waardoor de cel normaal blijft functioneren. Anderzijds blijkt de endotheelcelreactiviteit wel beïnvloed te worden door de vetzuursamenstelling van de membraan, in die gevallen waarin vetzuren aktief deelnemen aan membraangeassocieerde processen tijdens celactivatie. 


\section{List of Publications}

Vossen R.C.R.M., van Dam-Mieras M.C.E., Lemmens P.J.M.R., Homstra G., Zwaal R.F.A. 1991. Membrane fatty acid composition and endothelial cell functional properties. Biochim. Biophys. Acta. 1083: 243-251

Vossen R.C.R.M., van Dam-Mieras M.C.E., Hornstra G., Zwaal R.F.A. 1991. Eicosanoid production and membrane related properties of endothelial cells after fatty acid modification in vitro. In: Advances in Prostaglandin, Thromboxane and Leukotriene Research (Paoletti P., ed.) V21, Raven Press, New York, pp. 237-240

Vossen R.C.R.M., Feijge M.A.H., Heemskerk J.W.M., van Dam-Mieras M.C.E., Hornstra G., Zwaal R.F.A. 1993. Long-term fatty acid modifications of endothelial cells: implications for arachidonic acid distribution in phospholipid classes. J. Lipid Res., in press

Vossen R.C.R.M., van Dam-Mieras M.C.E., Hornstra G., Zwaal R.F.A. 1993. Lipid peroxidation of phospholipid liposomes is influenced by their fatty acid composition. Am. J. Clin. Nutr., in press

Vossen R.C.R.M., van Dam-Mieras M.C.E., Hornstra G., Zwaal R.F.A. 1993. Continuous monitoring of lipid peroxidation by measuring conjugated diene formation in an aqueous liposome suspension., submitted for publication

Lichtenbeld, H.H.C., Vossen, R.C.R.M., Muller, A.D., van Dam-Mieras, M.C.E., Bomans, P.H.H., and Blijham, G.H. 1993. Lipid peroxidation of the endothelial cell membrane: a possible mechanism in tumor angiogenesis?, submitted for publication

Muller, A.D., Lichtenbeld, H.H.C., Vossen, R.C.R.M., Muller, A.D., van DamMieras, M.C.E. 1993. Mast cells: a paradox in coagulation., submitted for publication 


\section{Curriculum Vitae}

Renée Catherine Robert Marie Vossen

24 december 1962 Geboren te Maastricht

1975-1981

1981-1987

februari 1985

Studente Gymnasium B(Serviam Scholengemeenschap, Sittard)

Studente Chemie (Rijksuniversiteit Utrecht)

Kandidaatsexamen Chemie

Hoofdvak: Biochemie (Prof. Dr. H. van den Bosch, Rijksuniversiteit Utrecht)

Bijvak: Haematologie (Prof. Dr. B.N. Bouma, Academisch Ziekenhuis Utrecht)

november 1987

Doctoraalexamen Chemie

1987-1992

Assistent in opleiding (AIO) bij de vakgroep Biochemie (Faculteit der Geneeskunde, Rijksuniversiteit Limburg, Maastricht) 


\section{Nawoord}

Het hier beschreven onderzoek is uitgevoerd binnen de vakgroep Biochemie, in prettige samenwerking met Humane Biologie en Medische Microbiologie. Daarbij zijn heel wat mensen betrokken, waarvan ik veel heb geleerd en die ik hier graag wil bedanken.

In het bijzonder:

- Rietje van Dam-Mieras voor de goede begeleiding en het mij volop de vrijheid geven voor een eigen invulling van het onderzoek, voor de stimulerende discussies, waardevolle adviezen, en je altijd optimistische uitstraling; kortom voor de prettige en leerzame samenwerking

- Rob Zwaal voor de deskundige en waardevolle adviezen, het vertrouwen in mijn onderzoekswerk, en de (altijd snelle en leerzame) manuscript-correcties, vooral in de laatste fase van het onderzoek

- Gerard Hornstra voor het in mij gestelde vertrouwen en je waardevolle bijdragen (als begeleider-zonder-tijd, zoals je het zelf noemde)

- Puck Muller voor de prettige en gezellige tijd als kamer- en labgenote, en je hulp, samenwerking en goede zorgen, zowel op wetenschappelijk als persoonlijk vlak

- Johan Heemskerk en Marion Feijge voor de prettige samenwerking, jullie grote vakkundige bijdrage, en de talrijke vruchtbare discussies

- Marianne Simonis en Jos Stegen voor alle hulp met de gaschromatograaf, en de gezelligheid op het lab

- Hera Lichtenbeld voor je behulpzaamheid en de fijne en gezellige samenwerking

- Edouard Bevers, Wiel DeBie, Paul Bomans, Cathrien Bruggeman, Paul Comfurius, Jorike Endert, Marieke Dormans-Linssen, Hans van Eijk, Albert van Geelen, Rein van Gool, Paul Lemmens, Wil Mullers en Carina Pernot voor de prettige en produktieve samenwerking

- Dr V.W.M. van Hinsbergen, Dr. Erna Langeler, Dr. J.A. van Mourik en Herman-Jan Brinkman voor de prettige samenwerking

- Prof. Dr. P. Brombacher en Dr. Hans van Pelt voor de gastvrijheid in het klinisch-chemisch lab (ziekenhuis De Wever) en de kritische discussies

- I want to thank Prof. Dr. F. ten Hoor, Prof. Dr. L.L.M. van Deenen, Prof. Dr. J. Jolles, Dr. P.J. Sims, en Prof. Dr. G.J. van der Vusse for critically evaluating this thesis 
- Mieke Janssen, Marion Feijge, Monique Al, Margret Foreman-van Drongelen, Anita Badart-Smook, en Threa Cremers voor jullie nauwgezette en belangeloze inzet bij het ophalen van de navelstrengen

- De afdeling verloskunde van ziekenhuis De Wever in Heerlen voor het zorgvuldig verzamelen van de navelstrengen en de Bloedbank ZuidLimburg voor het afstaan van humaan serum

- Mariet Molenaar voor de gezelligheid en je hulp met posters, manuscripten, en vooral in de laatste fase met de layout van het proefschrift, en Jan Kuipers voor je enthousiaste bijdrage aan de layout

- Paul Devilée voor de gezellige tijd en je "verhelderende" koffiediscussies

- I want to thank Monica Galli for the social time we spend inside and outside the laboratory

- De medewerkers van 'de spoelkeuken' voor de continue verzorging van het glaswerk en de sterilisatie

- De (oud)medewerkers van Biochemie en Humane Biologie voor de productieve werksfeer

- De (oud)medewerkers van Medische Microbiologie voor alle hulp met de weefselkweek, en bij wie ik altijd met vragen terecht kon

- De (oud)collega's van de AIO-vereniging (AVRL) voor de prettige en leerzame tijd

- De (oud)bewoners van Huize Waber voor de plezierige tijd en de belangstelling voor mijn onderzoek.

- en natuurlijk Michel.......

Tenslotte wil ik alle familie, vrienden en bekenden die op enige wijze een bijdrage hebben geleverd, maar niet met name zijn vermeld, van harte bedanken. 
